Florida International University

FIU Digital Commons

$5-20-2020$

\title{
A Qualitative Study of the FPCU Student Experience and Outcomes After Graduation within the South Florida Region
}

Tania Frederic Abouzeide

Florida International University, tfred001@fiu.edu

Follow this and additional works at: https://digitalcommons.fiu.edu/etd

Part of the Higher Education Commons, and the Higher Education Administration Commons

\section{Recommended Citation}

Abouzeide, Tania Frederic, "A Qualitative Study of the FPCU Student Experience and Outcomes After Graduation within the South Florida Region" (2020). FIU Electronic Theses and Dissertations. 4523. https://digitalcommons.fiu.edu/etd/4523

This work is brought to you for free and open access by the University Graduate School at FIU Digital Commons. It has been accepted for inclusion in FIU Electronic Theses and Dissertations by an authorized administrator of FIU Digital Commons. For more information, please contact dcc@fiu.edu. 


\title{
FLORIDA INTERNATIONAL UNIVERSITY
}

\author{
Miami, Florida
}

\section{A QUALITATIVE STUDY OF THE FPCU STUDENT EXPERIENCE AND OUTCOMES AFTER GRADUATION WITHIN THE SOUTH FLORIDA REGION}

A dissertation submitted in partial fulfillment of

the requirements for the degree of

DOCTOR OF PHILOSOPHY

in

HIGHER EDUCATION

by

Tania Frederic Abouzeide

2020 
To: Dean Michael R. Heithaus

College of Arts, Sciences and Education

This dissertation, written by Tania Frederic Abouzeide, and entitled A Qualitative Study of the FPCU Student Experience and Outcomes after Graduation within the South Florida Region, having been approved in respect to style and intellectual content, is referred to you for judgment.

We have read this dissertation and recommend that it be approved.

James Burns

Norma Goonen

Rebekah Schulze

Benjamin Baez, Major Professor

Date of Defense: May 20, 2020

The dissertation of Tania Frederic Abouzeide is approved.

Dean Michael R. Heithaus

College of Arts, Sciences and Education

Andrés G. Gil

Vice President for Research and Economic Development and Dean of the University Graduate School

Florida International University, 2020 


\section{ACKNOWLEDGMENTS}

First, I must thank my Lord and Savior Jesus Christ for without Him, I am nothing. Second, to my love, best friend and rock, Sandro J. Abouzeide, you are the light of my life and I could not have made it through this process without your unconditional love and support. Thank you for your encouragement and for being so incredibly understanding. You have earned this as much as I have. Your support has been unwavering and I am forever grateful to you. Thanks as well to Dr. Benjamin Baez. You saw something in me that I did not see in myself and I am indebted for your guidance and support throughout this journey. Thank you to my committee members, James Burns, Norma Goonen and Rebekah Schulze. To my family and friends, I thank you for your encouragement and welcomed distractions.

To Sophia and Sasha, my hope is that you never limit yourself, your capabilities and most importantly, your dreams. Continue to dream vividly in color. Take risks and surprise yourself. Always do your best and appreciate the mistakes while you celebrate your successes. Share your gifts with others and live with an open mind and kindness in your heart. I love you dearly. 


\begin{abstract}
OF THE DISSERTATION
A QUALITATIVE STUDY OF THE FPCU STUDENT EXPERIENCE AND OUTCOMES AFTER GRADUATION WITHIN THE SOUTH FLORIDA REGION
\end{abstract}

by

Tania Frederic Abouzeide

Florida International University, 2020

Miami, Florida

\title{
Professor Benjamin Baez, Major Professor
}

My study aims to explore why students enroll in for-profit colleges, outline their student experiences and present their post-graduate outcomes of obtaining a degree (i.e., increased salary, career progression, etc.) from an FPCU. With the rise of for-profit colleges, issues arise such as questionable recruiting practices, dismal graduation rates, poor job placements and minimal income increase and high student loan default rates (Deming, Goldin, \& Katz, 2013; Heller, 2011; Macqueen, 2011; Yeoman, 2011). The discourse surrounding for-profit colleges at times does not consider the FPCU graduate perspective those affected most by the FPCU notoriety. I interviewed 12 FPCU graduates from the South Florida area. Four major themes emerged from the qualitative study. Access and Choice, which relates to students' decision to pursue a higher education and the circumstances that influenced their college choice. The findings suggest that the research participants wanted to progress in their careers and sought employment opportunities. The second theme, Student Support, pertains to the student FPCU experience. The research participants reported that professor support was a substantial component of their student experience. The third theme, Degrees of Impact and 
Satisfaction, refers to post-graduate outcomes and specifically centered on how the respondents perceived their culminating collegiate experience. The respondents reported to have had a positive experience and were satisfied with their FPCU student experience and degree. The fourth theme, Returns on Investment, considers the financial investment component. The participants indicated the severity of their student loan debt from graduating from an FPCU. 


\section{TABLE OF CONTENTS}

CHAPTER

PAGE

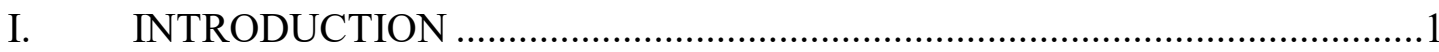

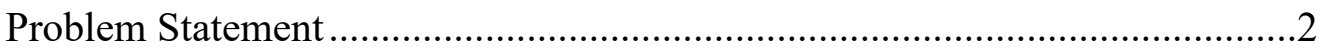

Purpose of Study ................................................................................... 7

Conceptual Framework ............................................................................ 7

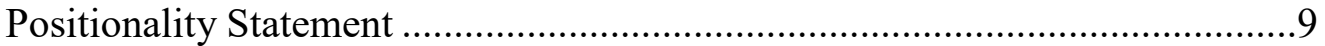

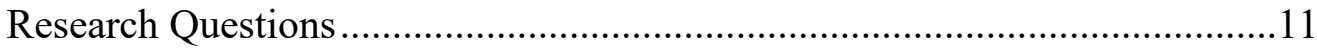

Assumptions and Delimitations of the Study...............................................11

Definitions of Key Terms .................................................................. 12

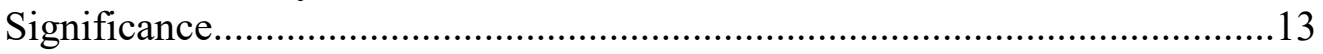

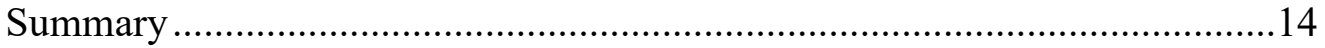

II. REVIEW OF RELATED LITERATURE ............................................... 16

Historical Overview of the For-Profit Institution Sector ..............................16

Growth and Prevalence of the For-Profit Institutions..................................19

The Role of the For-Profit Institution ..........................................................21

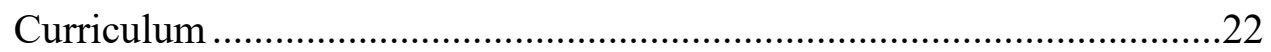

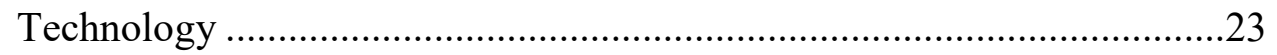

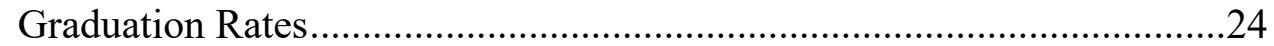

Customer Service and Management ......................................................25

Research on For-Profit Higher Education .................................................26

Current Climate of Higher Education Landscape \& the FPCU Sector.............30

Student Choice of For-Profit College ........................................................ 32

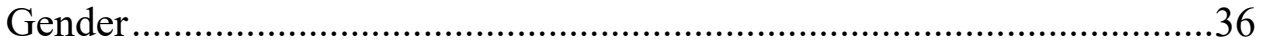

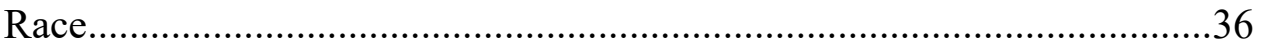

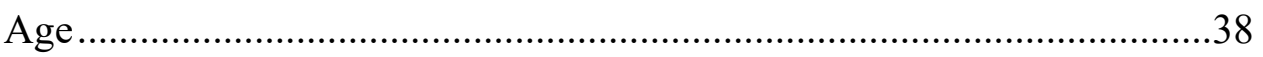

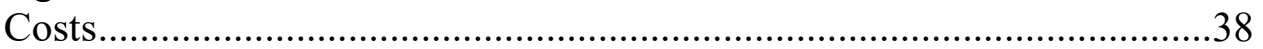

Financial Aid ................................................................................ 40

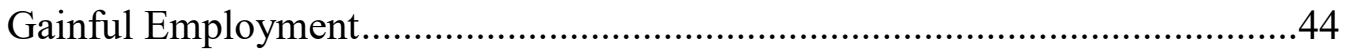

Outcomes and Returns of FPCU Students ....................................................45

Employer Perspectives of For-Profit Higher Education ..................................50

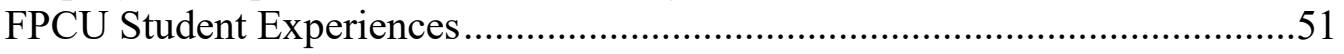

Counter Arguments and Recommendations ..............................................51

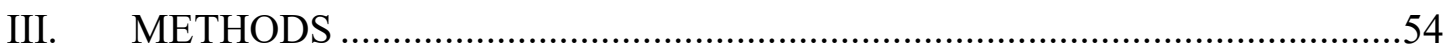

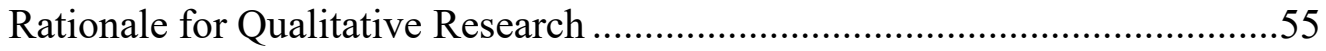

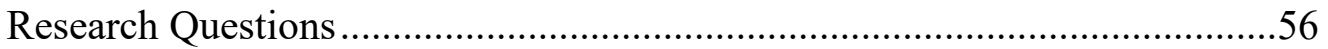

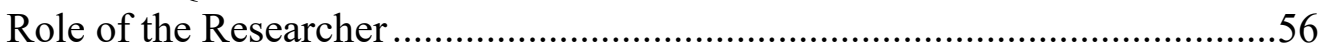

The Participants ....................................................................................58

Participant Recruitment and Access ...................................................59

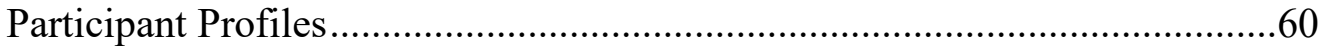

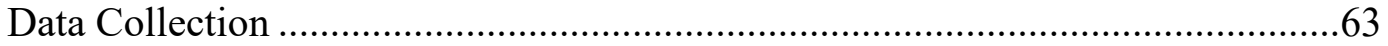

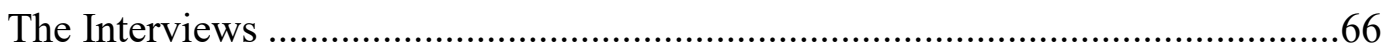




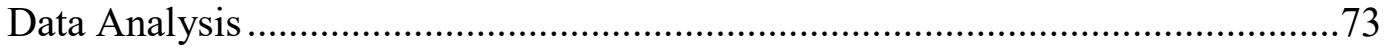

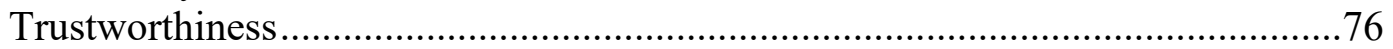

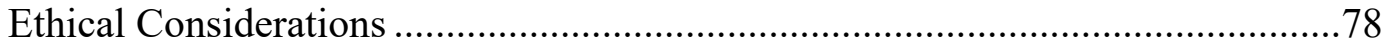

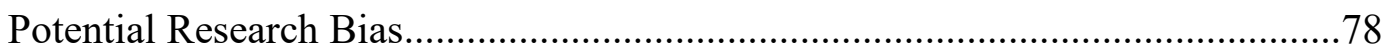

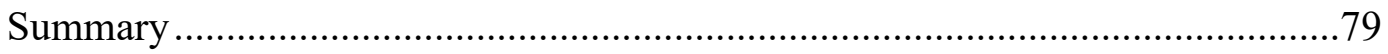

IV. FPCU and PARTICIPANT PROFILES ………...............................................

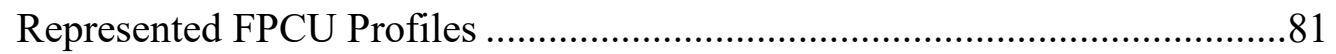

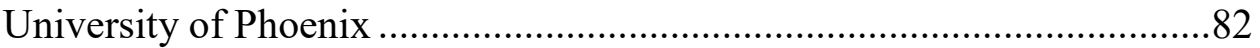

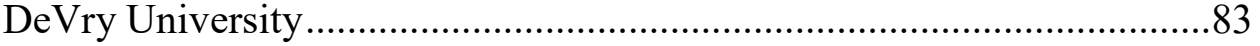

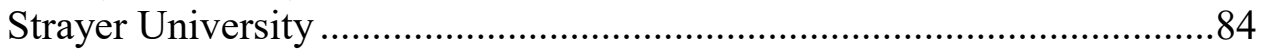

Argosy University, The Art Institutes and Brown Mackie College............85

Everest College (University).................................................................8

American Intercontinental University....................................................8

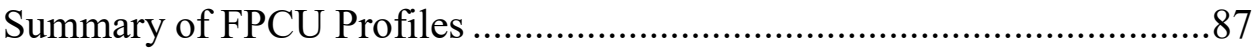

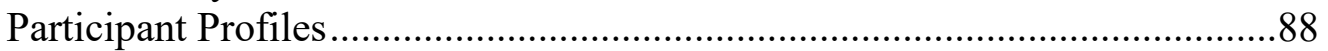

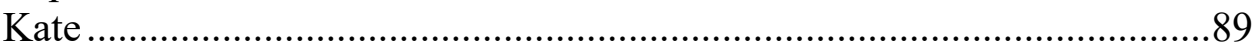

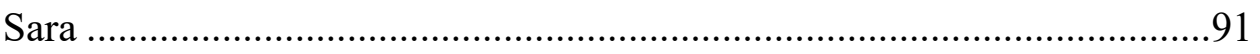

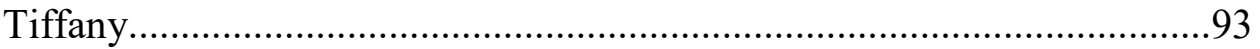

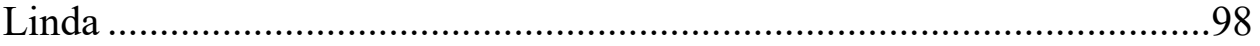

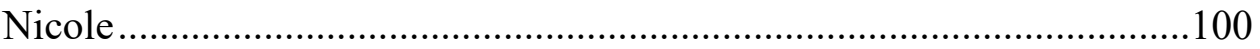

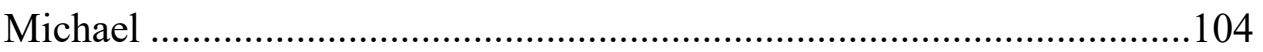

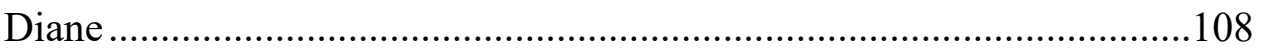

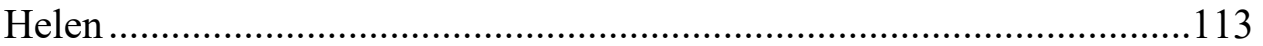

Amy

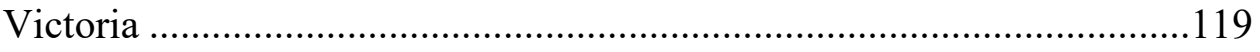

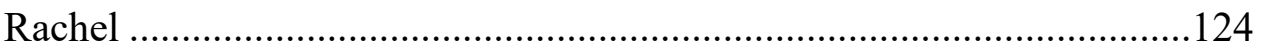

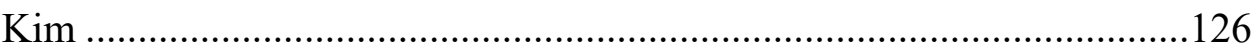

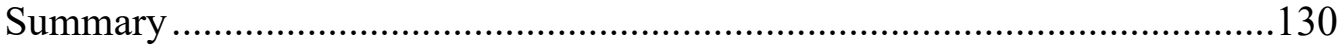

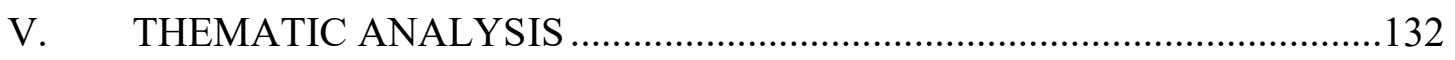

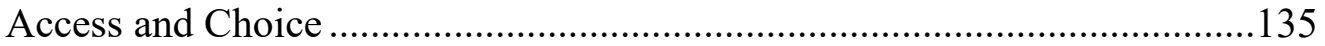

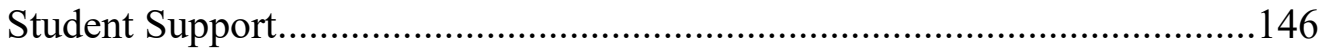

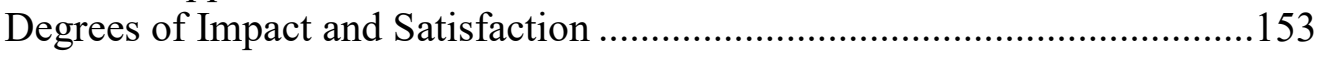

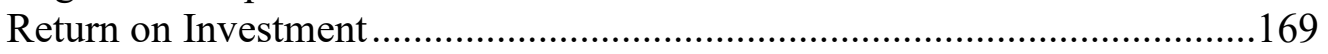

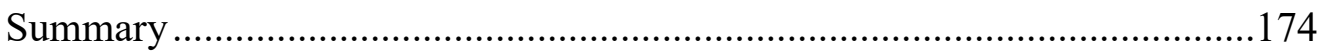

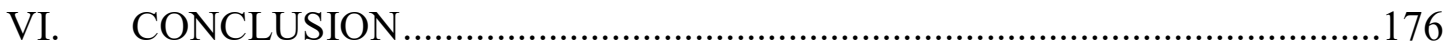

Reasons for Attending an FPCU..............................................................179

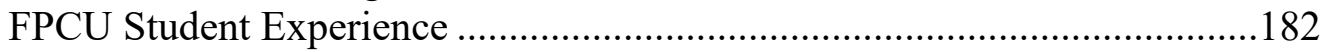

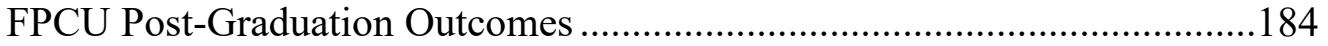

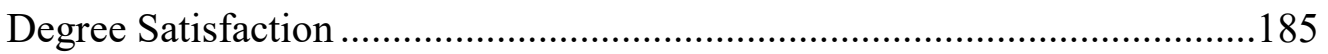

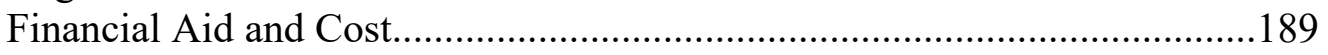

Recommendations for Future Research .......................................................190

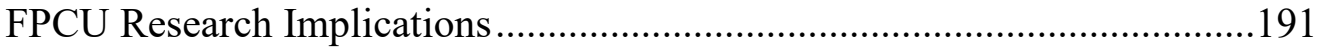

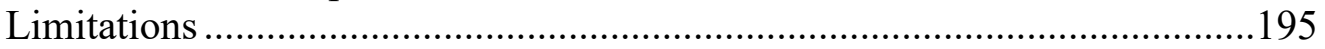




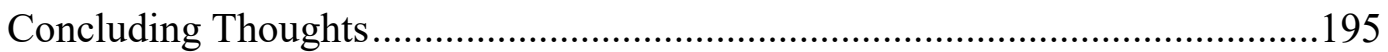

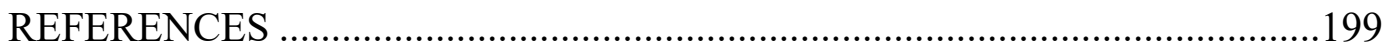

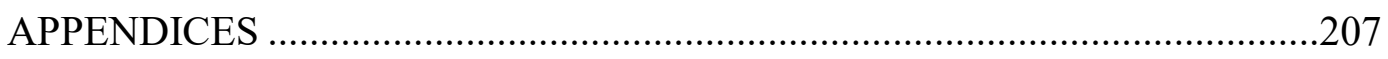

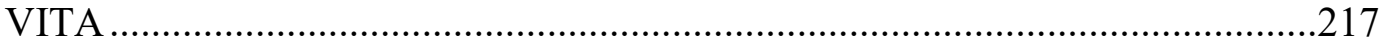




\section{CHAPTER I}

\section{INTRODUCTION}

Higher education and the prospect of obtaining a college degree is typically associated with positive outcomes, including social and economic mobility and personal success. These aspirations are linked to the achievements of those who earn a postsecondary credential. However, there is an increase in negative attitudes towards the costs and returns associated with obtaining a higher education, spurned by controversy and scandals of some for-profit colleges. Concerns such as soaring tuition expenses, high student debt, and low wage earnings (post-graduation) foster a climate which questions the value of a college degree (Deming, Goldin, \& Katz, 2013; Heller, 2011; Macqueen, 2011; Yeoman, 2011)

To some, the purpose of obtaining a higher education is to the betterment of oneself and thus society. Others may consider the college experience (leading to a degree) to be a rite of passage or they may have an inherent view of obtaining a higher education, being the result of family expectations/tradition. Many individuals perceive a college degree to be the gateway to a better quality of life. Today, it seems the purpose of obtaining a degree is a means to an end, the end being a job or career advancement. As Grubb and Lazerson (2004) put it "higher education is now the clearest embodiment of the American dream of getting ahead through one's own labor" (p. 56).

Nevertheless, the demand for higher education continues to increase in the United States (Deming et al., 2013). Along with the appeal of obtaining a college degree is the dilemma of access to higher education in the United States. The for-profit college sector aims to address the access gap in U.S. higher education. The sector's objective primarily 
serves non-traditional students (i.e., minorities, underserved, and disadvantaged students) with an opportunity to pursue a college degree (Berg, 2005).

According to Kinser (2006) and other higher education researchers, there are three sectors of higher education: the public non-profit, the private non-profit, and the private for-profit sector. The for-profit segment of higher education differs from the traditional public and private non-profit sectors concerning revenue (profit). The for-profit sector of higher education includes "privately funded taxpaying institutions that generate profit by providing post-high school degrees or credentials" (Iloh, 2016, p. 429). For-profit colleges and universities (FPCUs), also known as proprietary institutions, have persisted in U.S. higher education for longer than the general public has acknowledged (Kinser, 2006; Swenson, Warren \& Boggs, 2005). These schools contribute to the increasingly complex industry of higher education.

With the prevalence of for-profit institutions, issues often arise such as questionable recruiting practices, low-quality programs, dismal graduation rates, poor job placements, minimal income increase, and high student loan default rates (Deming et al., 2013; Heller, 2011; Macqueen, 2011; Yeoman, 2011). My study aims to explore not only why students enroll in FPCUs, but also explores their student experiences and their outcomes of obtaining a degree (i.e., employment, increased salary, career progression, etc.) from an FPCU.

\section{Problem Statement}

The pursuit of higher education in the United States evolved from an explorative ideal suitable for the privileged or intellectually curious starting in the 16th century to whereas now it is the pathway for career progress and the advancement of knowledge 
(research). From the onset of education in the United States, the discussion of education being a public civil right or private good has continued to be debated (Kinser, 2007). The goal of the for-profit college sector is to afford educational opportunities while making a profit. The purpose of the traditional higher educational sector is to afford educational opportunities while promoting societal advancement in the form of research and other knowledge seeking practices. As American higher education developed, so did its public purposes such as “benefits to the nation's economy, the protection of national defense, the creation of new knowledge, and the promise of equal education opportunities" (Grubb \& Lazerson, 2004, p. 56). However, the primary driving force of higher education is the private benefit, which includes idiosyncratic access to professional, financial, and economic advancement (Grubb \& Lazerson, 2004).

My study suggests that an inherent relationship across all sectors of higher education exists, while focusing specifically on the for-profit industry. However, the dichotomy between the non-profit traditional university and for-profit higher education is implicit. In fact, the awareness of the for-profit college sector relies heavily on what we know concerning the non-profit, traditional university ideology.

At the onset of my research of college students, I noticed that students within the traditional college and university sector are extensively studied. Published research ranging from student retention, student development theories, minority persistence, and first-generation students within the traditional university context are commonly referenced (Kurantowicz \& Nizinska, 2013; Johnson, 2017; Murphy \& Hicks, 2006). However, the larger higher education community neglects to include FPCU students and 
their experiences and in order to understand the for-profit college industry, one must understand the students that attend them.

Although for-profit colleges and universities provide opportunities for nontraditional students to pursue and complete a degree program, there appears to be adverse effects of attending an FPCU (Cottom, 2017; Mettler, 2014), considering reported predatory recruiting practices such as high student loan default rates, poor graduation rates, and questionable employment gains (Kinser, 2006; Deming et al., 2013). It is critical to determine if these institutions and the credentials they grant are equivalent to the traditional public and private non-profit universities and colleges.

Unethical and perhaps shady recruiting practices on behalf of for-profit colleges occasionally make headlines. One does not have to look far to witness the questionable sales pitch some for-profit colleges use. Take for example the commercials of for-profit colleges like now defunct Everest University (now operated by Zenith Education Group). They usually begin with a relatable person speaking directly to the camera with a directive saying, "Get off that couch and pick up the phone" or "Start your journey to a better your life." After the directive, the person tells the audience that financial aid is available and the school will help you land a job. These commercials follow a very simple formula to lure in prospective students. However, for-profit colleges and universities use various sophisticated methods to recruit students, such as overemphasizing accreditation credentials (Douglass, 2012; Howard-Vital, 2006), job and salary outlooks (Mettler, 2014), and financial aid impacts.

As discussed in Chapter Two, upon an investigation conducted by the Government Accountability Office, over $86 \%$ of the schools investigated provided 
"deceptive information" to prospective students and participated in fraudulent and misleading practices (Mettler, 2014). For example, one enrollment advisor indicated that with an associate degree in criminal justice an applicant would qualify for employment as an agent with the Federal Bureau of Investigation (Mettler, 2014). A beauty school enrollment advisor overstated the earning potential for a barber to earn up to $\$ 250,000$ annually when the national average is approximately $\$ 43,000$ annually (Mettler, 2014). However, the deceptive practices are not limited to recruiting practices.

There are reports of for-profit colleges taking advantage of the federal financial aid policies (Macqueen, 2012; Mettler, 2014). For example, The Institute for College Access and Success (2019) reported that FPCU bachelor degree graduates incurred $\$ 39,900$ in student loans and post-graduation, private non-profit graduates had $\$ 31,450$ in student debt and graduates from public institutions incurred $\$ 26,900$. Macqueen's research indicated almost half of the national student loan default rate is attributed to FPCU students (Macqueen, 2012). According to Kreighbaum (2019), the for-profit student loan default rate is $15 \%$. The public and private non-profit default rates are $9.6 \%$ and $6.6 \%$ respectively (Kreighbaum, 2019). Further, the low FPCU graduation rate, which is around $25 \%$, is considerably lower than the traditional six-year graduation rate at public and non-profit private colleges, $60 \%$ and $66 \%$ respectively (National Center for Educational Statistics, 2020; Yeoman, 2011). Beyond the ambiguous marketing efforts, loose federal financial aid policies and poor graduation rates, the FPCU sector continues to persist in spite of national headlines and consumer class-action lawsuits citing exploitation and unethical practices. 
The discourse surrounding for-profit colleges and universities at times does not consider the FPCU graduate perspective, those affected most by the FPCU notoriety. My study aims to enhance the for-profit college conversation by studying the students who actually attended these institutions. The FPCU graduate perspective is important to examine because their reasons for attending a non-traditional university or college may offer insight regarding their student experience pursuing a degree at an FPCU and essentially the perceived and tangible returns on their investment as a student. Kinser (2006) reported that over 3,000 for-profit institutions enroll about 800,000 students nationally. The National Center Education Statistics reported that in 2017 there were over 19 million college students enrolled across public, private and for-profit colleges; with over 1 million students enrolled in for-profit colleges (National Center for Educational Statistics, 2018, Table 317.40)

The present study explores the following vital concerns: 1) Specifically from a financial, economic and time preference perspective, are FPCU students considering all available options of which college to attend? 2) What are the experiences of FPCU students and do they themselves value the FPCU experience? 3) Are these institutions providing a quality credential and thus an opportunity for graduates to progress in their career and achieve economic mobility? My study probes the for-profit graduate experience. Through qualitative inquiry, the current study discovers the motivations, underlying reasons and insight into the FPCU industry and the students that graduate from such institutions. 


\section{Purpose of Study}

The purpose of my study is to determine not only the viability of pursuing and obtaining a post-secondary degree from a for-profit college, but also to explore the FPCU student experiences in a comprehensive manner. Few studies consider the FPCU student/graduate perspective. As a result, it is unclear what implications may or may not exist for the FPCU student demographic. Understanding the FPCU sector from a student perspective will provide additional insight into regarding how to mitigate potential damages and adverse effects of the for-profit industry. It would be beneficial to uncover how and why students select for-profit schools over affordable community colleges or comparably priced private non-profit colleges. Essentially, why would students absorb and risk high debt to attend a less recognized institution? Traditionally, it is understood that obtaining a degree from a reputable institution, such as Duke University, will result in increased earnings and better outlook on employment opportunities.

\section{Conceptual Framework}

In considering a suitable theoretical framework to guide my study, I heavily leaned on Grubb and Lazerson's (2004) education gospel concept. The education gospel as developed by Grubb and Lazerson (2004) is the belief system that postulates the benefits of education as a pathway to success via individual employment gains. The faith surrounding the education gospel centers on education and the pursuit of more schooling or credentials to develop and prepare individuals for the workforce. It is "the notion that the Knowledge Revolution is changing the nature of work, shifting away from occupations rooted in industrial production to occupations associated with knowledge and information" (Grubb \& Lazerson, 2004, p. 1-2). Grubb and Lazerson's Education Gospel 
belief system insists that these occupations mandate skills that can only be obtained beyond what high schools offer and that some college education is required to keep pace with future professions and occupations (Grubb \& Lazerson, 2004). The Education Gospel touches on "vocationalism" which reinforces the need to develop a workforce through schooling and curricula, with skills employers demand.

However, the education gospel does not stop at mere more schooling; rather, individuals who place faith in the education gospel may engage in life-long learning to stay abreast with rapid occupational changes and technology (Grubb \& Lazerson, 2004). Grubb and Lazerson's (2004) framework emphasizes the adaptability of higher education institutions to the labor market demands while balancing the original public and private missions of the university: advance society through knowledge seeking behaviors (research) and propel individuals to their desired professional objective. As Grubb and Lazerson (2004) indicated, that higher education serves as the avenue to achieve the American dream.

The fallacy with the concept is that it appears that American higher education has monopolized the pathway of professional success and advancement. Historically, the model of professional advancement heavily relied on hands-on experience rather than school-based learning. Now the model has shifted, as Grubb and Lazerson (2004) indicated:

As formal schooling displaced experience and apprenticeship methods, higher education standardized the necessary expertise by using easily recognized criteria to certify professional knowledge - entrance 
examinations, formal courses of study, degree requirements, and licensing examinations.

As an educator and higher education professional, I knowingly subscribe and believe in the education gospel. Through my personal experiences, the Education Gospel has become innate and a guiding principle in my professional and personal aspirations. As I write my dissertation for my own career advancement, I consider how my personal academic credentials have played a role in my journey of self-discovery and professional success. For many of the participants in the current study, they also subscribe to the belief system whether knowingly or not. Therefore, I use the education gospel as the foundation and backdrop for my study. From the pre-enrollment phase throughout the academic journey to graduation, the education gospel serves as a solid framework to apply to the present study because in this context, it describes how individuals perceive their pursuit of a college degree, including outcomes related to economic mobility.

\section{Positionality Statement}

The present study aims to explore the decision-making process, the experience, and outcomes of students who graduated from a for-profit college or university in the South Florida region. As a former college advisor, current university administrator and instructor, I am passionate about imparting knowledge to students and believe in education as a pathway to success. As a trained counselor, I understand the importance of decision-making and having as many tools and information to make an informed decision. Therefore, I am interested in uncovering what factors participants considered and factors that led them to their decisions. Seeing that the study also focuses on participants' experiences at a for-profit institution (rather than at a traditional college), 
my primary objective is to explore the effects of the for-profit education market, especially if the participant(s) experienced positive outcomes, professional growth, and financial progress.

As a higher education professional, I have personally witnessed the adverse effects of students attempting to transfer from a for-profit institution to a traditional public university. As a former college advisor, I have had to communicate and explain the differences between accreditation bodies and transferability rules, the results of which were not in students' and some graduates' favor. Therefore, my experiences have shaped my purview of the for-profit market as I have had to work directly with this student population and have established a personal connection with this student demographic and identify with a similar experience to selected participants. Ultimately, the purpose of this study is to contribute to the discussion of for-profit institutions and their students. A component of the present research includes the debt and financial investment students make. In addition to understanding their experience, I intend to examine the outcomes of each participant. Some considerations include if graduates have an improved financial situation or if they are riddled with debt, perhaps more debt than they would have incurred at a public institution. I aim to obtain information pertaining to their career goals and if they achieved professional growth as a result of their degree. Finally, I am interested in acquiring a comprehensive narrative of their FPCU experience, how the participants viewed their student experience, and their overall satisfaction of their experience. 


\section{Research Questions}

The current study aims to shed light from the FPCU graduate perspective concerning their career prospects, financial and economic standing, and other achievements, specifically within a saturated for-profit market in South Florida. Additionally, the study aims to contribute to the discourse on for-profit college recruiting practices, transferability prospects, potential career advancement or entry, and economic standing upon graduating from a for-profit college. Therefore, the study aims to answer the following research questions:

1. Why did FPCU graduates choose to attend a for-profit college?

2. What were the experiences of FPCU graduates in college?

3. What were the FPCU graduates' experiences upon completing their degrees?

I will seek to understand the perceptions and experiences of graduates of for-profit colleges. In particular, I will examine how students made their decisions and what factors they considered as they made their decision. It is also critical to understand their perceived experience as an FPCU student within their courses, programs, and exposure to administrative procedures (i.e., admissions, registration, financial aid, student affairs, etc.). Further, I intend to evaluate and explore outcomes after graduation. Specifically, did the graduate secure employment, a promotion, or other career progression?

\section{Assumptions and Delimitations of the Study}

The current study aims to explore the experiences of FPCU students from their interpretative perspective. The study is limited in that it focuses on student experiences, which rely on perceived memory and are subjective. One may assume that the results of 
the study will not be generalizable because of the small sample size and the sample was restricted to the South Florida region.

A major assumption of the current study is that attending college is good, positive, and enhances the economy and individual. The purpose of pursuing and completing a degree regardless of where, when, and by whom, can be interpreted as progress for the individual and society. The assumption rests on the notion of the education gospel, which was discussed earlier in this chapter.

\section{Definition of Key Terms}

The following key terms will be used in this study: IHE (institutions of higher education, FPCU (for-profit college and university), traditional universities, financial aid, and qualitative research. The following presents the definitions of these terms found throughout research study.

Institutions of higher education or IHE refers to the collective body of colleges and universities that grant post-secondary (after high school) education. Institutions of higher education relates to all degree granting institutions, regardless of accreditation. There are three sectors within the higher education industry, private non-profit, public non-profit, and private for-profit (i.e., Harvard University, University of California, Los Angeles and University of Phoenix, respectively) (Kinser, 2006).

For-profit colleges and universities or FPCUs, refers to all post-secondary institutions that generate revenue in the form of profits. They are also known as proprietary schools or career colleges. For-profit colleges and universities is used to describe the for-profit education industry within a higher education context. 
The term traditional university refers to the private or public non-profit college or university, the most well-known traditional university being Harvard University. Traditional university typically implies that a college or university is traditional and that most students complete their degree in four years. These schools offer bachelor's, master's and $\mathrm{PhD}$ degrees and are governed by a board and regional accreditation body. Any revenue generated must be applied back to the college or university.

Within the current study, the term financial aid pertains to monies and funds in the form of loans, grants and scholarships for the use of tuition related expenses. Federal financial aid policy in the US is a complex set of guidelines in which students must apply and meet eligibility requirements to receive funds for the purpose of obtaining a postsecondary credential.

The present study uses the term qualitative research to specify the research method/approach. Qualitative research or methodology refers to the ideology that "meaning is socially constructed by individuals in interaction with their world" (Merriam, 2002). My approach is primarily exploratory and is used across many disciplines, including to uncover perceived interpretations, attitudes, and incentives within a certain context.

\section{Significance}

The significance of my study will add to the body of research surrounding the FPCU industry. However, rather than focusing on macro-level concerns such as educational policy, my study will address the student perspective and experience. The FPCU student voice is deserving to be heard and requires attention. The FPCU student demographic is likely an adult minority (specifically black or Hispanic) female within the 
lower socioeconomic stratum (Cottom, 2017; Mettler, 2014). Therefore, the current study implies a level of academic exploitation and educational inequality on behalf of the FPCU industry. The student demographic, along with the above-mentioned infamy of the FPCU industry, appears to be intentional, at first glance. However, a qualitative study within a culturally rich region, such as South Florida, will provide insight into how FPCU graduates perceive their experiences and interpret their outcomes. The results of my study contribute to the overall discussion surrounding the for-profit student experience, higher education worth, value, and return on investment.

\section{Summary}

The FPCU industry requires an understanding of the development of the U.S. higher education system and the intended mission of higher education. An FPCU sector is a complex set of institutions that differ from the traditional non-profit colleges and universities in a manner that focuses on revenue generation while decreasing costs. While traditional colleges and universities also generate revenue, they are required to apply any profit generated back to the institution, whether to update facilities or use funds to provide scholarships. For-profit colleges, like traditional colleges and universities, also grant degree credentials in many disciplines, yet the cost of attendance is typically higher at a for-profit institution, which denotes the question of degree worth. Public policy also heavily shapes the higher education landscape. Although each sector of higher education is unique, the for-profit industry is particularly notorious for high tuition rates, poor graduation rates, and is often the subject of several lawsuits. My study aims to explore why students attend them, how they made their decision, what their experiences were 
like, and what were the outcomes of obtaining a FPCU credential within the South Florida region.

The ensuing literature review explores the increasing interest of for-profit institutions within the higher education market in the United States. Access and choice are significant components of higher education. Therefore, using access and choice theories of higher education frameworks, researchers examine for-profit student choice and the factors associated with the decision to enroll at a for-profit college. Financial aid and economic resources also serve as a critical element in exploring FPCU student choice. I will present and discuss significant studies addressing the aspect of financial assistance of the for-profit market. Lastly, research studies regarding the outcomes of forprofit students and graduates are included to discuss what the potential returns and benefits are after enrolling in a for-profit college. The implications of these studies refer back to the questionable recruiting practices and marketing claims of the for-profit industry. Further, I address the FPCU student perspective and counter arguments supporting the for-profit sector. 


\section{CHAPTER II}

\section{REVIEW OF RELATED LITERATURE}

According to Deming, Yuchtman, Abulafi, Goldin and Katz (2016), FPCUs "account for 42\% of postsecondary enrollment growth from 2002 - 2012" and in 2012 more than 1.1 million students were enrolled at the 23 largest for-profit institutions (p. 779). The overall narrative of the for-profit industry is mostly negative, yet as demonstrated by enrollment numbers, the for-profit industry is secure and here to stay. Research on the for-profit sector of higher education encompasses either student choice factors, including a large body of work on financial aid implications and the returns of the for-profit market. Quantitative studies examining the economic costs and benefits of the FPCU credential is reported and valued. Qualitative studies investigating student choice provide a solid foundation for understanding under what circumstances students enroll into a for-profit college. But often the FPCU alumni viewpoint is neglected. Few qualitative studies consider the FPCU student experience and outcomes after graduation, including their economic status and professional growth (i.e., career advancement or promotion). Therefore, the current study aims to shed insight from the FPCU graduate perspective regarding their experiences beginning from the student college choice process through FPCU matriculation and outcomes after graduation.

\section{Historical Overview of the For-Profit Institution Sector}

To understand the current role of for-profit institutions of higher education, one must consider the historical origins of for-profit institutions. Dr. Kevin Kinser's research on the for-profit institution has established him as an expert in the field. He has contributed to the current literature on alternative and non-traditional higher education, 
including for-profit institutions. Kinser's (2006) study focused on the history of the forprofit sector as well as a general sector profile (Kinser, 2006, 2007; Floyd, 2007; Schilling, 2013). For a historical overview on for-profit institutions, Kinser's work is primarily referenced. In addition, the work of Jo Anna Schilling (2013) is included in the historical perspective of for-profit institutions.

The origins of proprietary institutions date back to as early as the $16^{\text {th }}$ century (Douglass, 2012; Kinser 2006; Schilling 2013; Urman, 2007). For example, many schools in Western Europe specialized in handwriting, bookkeeping, and business. Dutch night schools in Colonial America provided practical skills required for jobs (Urman, 2007). According to Kinser (2006, 2007), not only have for-profit institutions existed since the $18^{\text {th }}$ century in the United States, along with traditional public and private institutions, but they have also played a vital role in the U.S. educational system.

Kinser (2006) indicated that the current model of for-profit institutions arose from the private business colleges of the 19th century. As a consequence of the increasing sizes of businesses, the apprenticeship system was no longer effective (Kinser, 2006). As a result, training of new employees was required in a more systematic method, thus the creation of business colleges by entrepreneurs (Kinser, 2006). While the for-profit sector continued to expand with business colleges, universities began to offer the same vocational programs, which undermined the for-profit business college (Kinser, 2006). Although the for-profit sector remained firmly intact with servicing new incoming students in the early 1900s, the sector was altered with the passing of the Smith-Hughes Act of 1917. The Smith-Hughes Act of 1917 required vocational education to be encompassed in public schools (Kinser, 2006; Schilling, 2013). In addition, a second 
blow was dealt to the proprietary sector with the GI Bill post World War II (Kinser, 2006; Schilling, 2013). As a result, the for-profit sector witnessed significant enrollment declines caused by the initial exclusion of for-profit institutions, under the GI Bill guidelines (Kinser, 2006; Schilling, 2013). However, with the influx of returning soldiers seeking enrollment and congressional consideration, for-profit institutions became eligible for federal funding in the late 1940's (Kinser, 2006; Schilling, 2013).

Upon the inclusion of proprietary institutions under the GI Bill, institutional accreditation concerns arose, resulting in the National Defense Education Act of 1958 (Kinser, 2006). The National Defense Education Act of 1958 served as the foundation of the Higher Education Act of 1972, which expanded additional federal financial aid (i.e., student loans) to students in vocational and for-profit institutions (Kinser, 2006; Schilling, 2013). The implementation of the Higher Education Act of 1972 resulted in regional accreditations granted to for-profit IHE's (Kinser, 2006).

In the 1980 s, there were upwards of 4,000 for-profit schools with almost two million students enrolled nationally (Schilling, 2013). The 1990's signified the modern upsurge of the for-profit sector. The corporate-owned institution further solidified the Wall Street era with the initial public offering (IPO) of the Apollo Group in 1994 (Kinser, 2006; Schilling, 2013). Leading into the $21^{\text {st }}$ century, the for-profit sector has maintained its position within the higher education arena. Nationally, out of 3,500 for-profit institutions, 800 are degree granting (Kinser, 2006). Total revenue for this sector was $\$ 6.2$ billion, with 800,000 enrolled students (Kinser, 2006).

Prior to the aforementioned historical origins of the for-profit sector, one might assume that for-profit institutions are quite new in the general scope of higher education. 
However, contrary to general perception, Kinser $(2006,2007)$ and Schilling (2013) accurately contradict the assumption. Recent class action lawsuits and the abrupt closing of some institutions has attributed to the negative public perception of the for-profit institutions, while not realizing that these institutions are not new to the American higher education landscape. Kinser (2006) addressed and noted several previous works where the author indicated that there is a significant gap in the literature on the for-profit sector and the claim of "lack of information" on for-profit IHEs is not factual (p. 3). Both Kinser (2006) and Schilling (2013) referenced works dating back to the early $19^{\text {th }}$ century. In addition, Kinser (2006) specifically addressed that enrollment records "can be traced back to the 1870 's" (p. 3). Although there is a plethora of information on the forprofit sector, the main factor for a lack of understanding is that the for-profit sector is constantly changing, thus the difficulty of understanding the sector (Kinser, 2006). However, viewing the historical development of the for-profit institution provides a solid foundation regarding the sustained growth of a changing higher education market.

\section{Growth and Prevalence of the For-Profit Institutions}

Higher education in the United States has witnessed unprecedented growth. The increasing demand of higher education is one of the causes of students seeking education at alternative, non-traditional, and mostly for-profit institutions (Macqueen, 2012). As a result of the general growth of higher education in the United States, the for-profit institution sector has managed to exhibit the large growth rates. Floyd (2007) cited that within the for-profit sector, there are two types of for-profit institutions: enterprise institutions (also known as independent schools) and multi-campus corporations (also known as corporate-owned institutions). In addition to being significantly smaller than 
their counterpart (in terms of enrollment and campuses), the enterprise or independent institutions are typically "locally or family-owned, and have a very informal structure and operating style" (Floyd, 2007, p. 122). The distinction between the two types of for-profit institutions is apparent. Subsequently, more attention is given to large multi-campus institutions because of sizeable enrollment, revenue, and degree conferrals (Floyd, 2007; Kinser, 2007). The majority of the growth within the for-profit sector is driven by corporate-owned and/or publicly traded for-profit institutions, which enroll about $50 \%$ of all students enrolled at for-profit degree granting institutions (Kinser, 2006). Many of the corporate-owned institutions are large national chains. Deming et al. (2013) found that "90 percent of the enrollment increase in the for-profit sector stemmed from these large national chains" (p. 138). Oseguera and Malagon (2010) also reported that for-profit colleges and universities (FPCUs) experienced tremendous growth. The researchers cited enrollment increased 91\% in degree-granting institutions, from 1998 to 2003 (Oseguera \& Malagon, 2010). Deming et al. (2013) also noted that enrollment in the for-profit sector has tripled since 2000. The Apollo Group, which is the parent company of the University of Phoenix, "enrolled 18 percent of all students in the for-profit sector and 26 percent of all degree-seeking students" in 2002 (Kinser, 2006, p. 23).

Although the for-profit sector has experienced tremendous growth, corporateowned institutions only accounted for $2.5 \%$ of all students enrolled in higher education in the United States (Berg, 2005). Douglass (2012) indicated that for-profit IHEs included about "2,900 institutions and affiliated campuses, representing more than $40 \%$ of all the accredited colleges and universities in the U.S. Yet their total enrollment is just less than $10 \%$ of all enrolments in the 50 states" (p. 247). It is clear that some for-profits are quite 
large and enroll high numbers of students (i.e. University of Phoenix). Considering the for-profit sector dominance, it is important to discuss the role corporate owned for-profit IHEs play.

In Kinser's 2007 study, Dimensions of Corporate Ownership in For-Profit Higher Education, the focus on corporate owned educational providers in higher education with respect to the changing dynamics of U.S. higher education was explored. In addition, Kinser (2007) surveyed both the smaller independent for-profit division and the Wall Street owned (large multi-campus corporations) sector. Curricular aspects of the efficient for-profit model, along with the myriad of unethical practices of for-profit institutions, were also examined. Kinser (2007) reported, "Wall Street owners are now the primary producers of for-profit degrees in the United States" (p. 227). The major players in the for-profit sect are: ITT, DeVry, Apollo, Laureate, Strayer, and EVCI. They primarily grant degrees, according to Kinser (2007). Concorde, Corinthian, Lincoln, and UTI mainly award non-degree certificates (Kinser, 2007).

Douglass (2012) attributed the rise of the for-profit sector to three factors: 1) increase in demand of higher education driven by population growth; 2) technological progress (i.e., the internet and online course offerings); 3) loosened federal regulation during the Bush administration. In addition, the growth of the for-profit institution sector is attributed to the dominance of Wall Street-owned institutions or the large multi-campus corporation (Floyd, 2007; Kinser, 2007).

\section{The Role of the For-Profit Institution}

Although sometimes marred by controversy and notoriety, the for-profit sector within higher education continues to service students and attempts to address the access 
gap in the United States. These institutions may be owned by individual proprietors, others by shareholders of multibillion dollar corporations, but all reject the claim that private gain trumps the broader service to students and society they provide (Kinser, 2006, p. 2). Berg (2005) argued that the "for-profit solution to the access problem is accomplished through an organizational model that concentrates on meeting the needs of ethnic minorities, adult, and first-generation college students" (p. 30). The following section briefly explores the current role of for-profit institutions and what they have to offer.

\section{Curriculum}

Deming et al. (2013) mentioned that for-profit institutions or proprietary institutions offer a large range of programs, from non-degree certificates to doctoral degrees, with various accelerated timeframes of completions. "They provide identical curriculum and teaching practices at multiple locations and at convenient times, and they offer highly structured programs that make timely completion feasible" (p. 139). Oseguera and Malagon (2010) supported the notion that for-profit institutions tend to offer accelerated programs with "hands on training" (p. 67). The majority of corporate owned institutions offer programs in business, computer science, and health care, with more than the majority of Wall Street owned schools offering at least one of the abovementioned programs (Kinser, 2007). Floyd (2007) stated "many for-profit colleges have entered the high-growth health sciences because of considerable employer demand and student interest" (p. 123). Cellini (2010) noted that many programs offered at the forprofit IHE are also offered at community colleges. However, the overcrowding of community colleges with an added decrease in state support contribute to why students 
choose the for-profit over the less expensive community college (Cellini, 2010). Nevertheless, additional student choice factors is covered in this chapter. In addition, Swenson et al. (2005) mentioned that the development of professional schools within traditional universities and colleges compete with the for-profit institution sector in terms of students and revenue, as the professional schools also generate revenue for the traditional university.

\section{Technology}

Technology and the advancement of online and distance learning capabilities has played a major role with respect to the growth of the proprietary institution sector. Technological progress with respect to the development of the internet and the World Wide Web has enriched the learning the process, especially from an institutional perspective. Flexibility, accessibility, and adaptability have become synonymous with online learning. In regards to the for-profit versus non-profit institutions, many for-profit institutions offer distance learning courses and online course components. However, per Deming et al., (2013), FPCUs are not more likely to offer technology assisted courses than community colleges.

For-profit institutions, particularly large national chains, offer specific programs in popular fields such as business and health care. Subsequently, the for-profit college and university agenda differs from that of the traditional university ideal (Berg, 2005). Berg (2005) stated that the primary charge of for-profit institutions is to educate working and/or professional adult students using a faculty practitioner model that is valued in place of the traditional faculty/scholar model. In addition, Berg (2005) noted that forprofit institutions face many challenges with increased scrutiny; however, those within 
the for-profit sector maintain a commitment to a larger social agenda, rather than just generating profits. In contrast, Deming, et al. (2013) argued that although for-profit institutions, specifically large national chains, provide educational opportunities to those underrepresented in the traditional higher education segment (minorities and disadvantaged students), low graduation rates should support the necessity for additional regulation.

\section{Graduation Rates}

Yeoman (2011) indicated the six-year graduation rate of $25 \%$ of for-profit institutions (35\% lower than that of private non-profit and almost $40 \%$ lower than public institutions), according to a 2010 U.S. Department of Education report. Blumenstyk (2012) offered insight into the critical graduation rate of for-profit institutions. She stated that each college company may use varying criteria to compute the essential graduation rate (Blumenstyk, 2012), as the graduation rate is a mandatory requirement for all U.S. institutions (public non-profit, private non-profit, and private for profit) to report for federal funding. Therefore, the $25 \%$ graduation rate of for-profit institutions may not be representative of the actual number of students graduating from for-profit institutions. Deming et al. (2013) reported slightly lower estimates of for-profit graduates, at 23\%. Although economic impacts will be explored later, it is important to note that approximately $23 \%$ of students who either graduated (after six years) or left the for-profit institution were unemployed (Deming et al., 2013). Deming et al. (2013) also concluded one major theme from their study on the educational opportunities of underprivileged students afforded by for-profit institutions: that the outcome of those who attend a proprietary institution will frequently result in no degree at all. 
The referenced literature highlighted low graduation rates of the for-profit institution sector, as rates are considerably poor in comparison to the non-profit sector. Graduation rates for associate degrees and higher, within the for-profit sector, are unfavorable (Deming et al., 2013; Yeoman, 2011). For-profit colleges tend to use "less stringent" admissions standards typically do not require standardized test scores such as the SAT (Bennett, Lucchesi, \& Vedder, 2010, p.31). Despite poor graduation rates, the for-profit sector continues to thrive and excel in areas seemingly lacking in the traditional sector. As a result, for-profit institutions remain attractive to the students who enroll in them. An organizational approach provides insight into business principles applied to the for-profit sector. Much of the literature on the for-profit sector highlights the efficient and managerial processes within the for-profit sector, as many of these institutions' parent companies belong to the corporate industry and adhere to business practices.

\section{Customer Service and Management}

Tierney (2011) claimed that "for-profit institutions represent a business model that fundamentally differentiates them from traditional colleges and universities" (p. 28). Deming et al. (2013) proposed that for-profit institutions "provide a more structured, supervised approach" (p. 146). Schilling (2013) also found customer service models and business practices within higher education. Berg (2005) supported the notion of business practices within the for-profit sector. He noted that while proprietary institutions provide service to minorities, they do not encompass specific ethnic academic or ethnic studentbased services (Berg, 2005). Rather, for-profit institutions employ a general student services or student-centered model of service, which heavily relies on business-based customer service principles (Berg, 2005). It is evident that the for-profit industry 
capitalizes on efficiency to generate revenue while providing educational opportunities to students while traditional institutions are notorious for hierarchical and bureaucratic nuances.

\section{Research on For-Profit Higher Education}

When studying the for-profit sector of higher education, researchers tend to focus on the expansion of the FPCU market from a comprehensive perspective. Beginning with the historical development of for-profit schools, through federal policies resulting in an expansion, researchers use student choice theories and examine enrollment numbers from government databases, to question why and how the FPCU market continues to thrive. Researchers study the "who" as in the student demographics, since they want to know which students are enrolling in FPCUs.

Regarding expansion of the FPCU sector, researchers provide the historical overview of FPCUs within their studies. The historical analysis is critical to understanding the current prevalence of today's for-profit market within higher education, because it encompassed how proprietary schools emerged in the $18^{\text {th }}$ century and experienced rapid growth with the passage of the GI Bill following World War II (Bennett et al., 2010; Chung, 2012; Kinser, 2006). Through the GI Bill, veterans could pursue a degree at traditional non-profit institutions and for-profit institutions using benefits. The Higher Education Act in 1972 established FPCUs as federal financial aid eligible, further solidifying the for-profit market (Bennett et al., 2010; Chung, 2012; Kinser, 2006). As a result, the for-profit market would expand and broaden degree programs offered and move away from "mom and pop" operations and transition into large national chains, operated by publicly traded companies (Kinser, 2006). Scholars 
consistently endorse that for-profit higher education could not thrive today without the two events above. The effects of the GI Bill and the Higher Education Act of 1972 paved the way for the for-profit market to provide educational opportunities to non-traditional students, thus adding to the discussion of access and choice in for-profit higher education.

The research on the for-profit sector contends that federal policies, mainly related to financial aid, resulted in greater access for students. However, to have a complete view, the student perspective (choice) must not be neglected. There is increased attention centered on examining student choice and what factors led to the decision to attend an FPCU. Perna (2006) discussed two major theoretical frameworks for college access and choice: the human capital investment model, which is from an economic perspective, and a sociological model of status attainment (Perna, 2006). For-profit education researchers commonly use the human capital investment model to explore student choice, although this theoretical concept initially applied to non-profit college choice theories (Oseguera \& Malagon, 2011; Rodriguez, 2014). The human capital investment theory considers economic factors against non-economic factors (i.e., money and time). Rodriguez (2014) stated that the model "refers to the balancing of costs, (i.e., financial costs, time) against the potential benefits to maximize personal advantage based on decisions made during the college selection process" (p. 149).

Other economic and sociological frameworks including rational choice are applied to studies exploring for-profit college choice, especially when comparing between community colleges and for-profit schools since they target the similar student populations and offer comparable programs (Cellini, 2010; Iloh \& Tierney, 2014). In the rational choice model, motivation is driven by the goals that are best aligned with 
individual preference (Iloh \& Tierney, 2014). In the case of for-profit college choice, an individual may select an FPCU over a community college since FPCU courses are shorter than the traditional 16 week semester and offered on a fixed and convenient schedule.

Researchers also use individual factors, rather than using a conceptual theory to examine for-profit college choice, such as race and ethnic background, economic status, community college access, and potential returns (Boykin, 2017; Oreopoulos \& Petronijevic, 2013). These studies are centered on a specific demographic either, Black or Latino students, or return factors (i.e., earnings and wages). However, a cost-benefit analysis is prevalent and is applied to FPCU choice studies.

Recruiting methods of FPCUs have garnered much negative attention in the public media, but less so within academia. The for-profit industry targets specific students, as demonstrated in the literature. Denice (2015) noted that the for-profit student is more likely to be Black and Hispanic, with lower high school achievement and stems from lower socioeconomic status families (Denice, 2015). Although the literature on FPCUs addresses questionable and potential fraudulent recruiting practices, researchers gloss over this recurring theme and provide detailed quantitative studies related to the growth the FPCU sector has achieved. Few studies examine the recruiting methods of the for-profit industry.

According to Tierney (2011), traditional colleges and universities have not marketed to "first-generation, low-income working adults" and admission departments of public institutions have "engaged in minimal marketing" because their "natural clientele and did not care about attracting the one the for-profit institutions were going after" (p. 28). However, recruiting practices within the for-profit institution sector are not without 
blemish. Douglass (2012) described it as "predatory recruiting practices" (p.252). Forprofit schools use accreditation status as part of their recruitment strategies. Howard-Vital (2006) discussed recurrent themes during her tenure in the University of North Carolina university system, in which she performed evaluations on the licensure process of institutions within the state of North Carolina. One major theme noted is that students could not differentiate between regional and national accreditation.

The research on for-profit education is increasing. However, because there is limited available data of the for-profit sector, researchers must refer to datasets to determine the general effects of the for-profit industry, from a quantitative approach. Researchers use government data obtained from the National Center for Education Statistics (NCES). The literature referenced for the present paper contains studies using data sets from longitudinal studies from 1988 through the early 2000s. Given that to determine benefits of either industry, quantitative comparative studies consequently result in a comprehensive understanding of for-profit higher education, this data include relevant information about emerging patterns from students who attended and earned credentials across the three sectors of higher education and data from high school graduates. Researchers engage in regression analysis, cost-benefit analysis, and use the Mincer model to assess the effects of training on earnings.

From the qualitative lens, researchers create their sample by recruiting participants from all sectors of higher education. Ethnographic methods, including case studies, interviews, and focus groups are commonly employed in these research studies. The results from these studies provide anecdotal evidence that supports the significant themes of for-profit research. Although research on the for-profit sector is increasing, the 
challenge lies with the shifting perspective of the FPCU industry. For example, public policy and regulation of the FPCU sector are directly affected by policies established by the Department of Education.

\section{Current Climate of Higher Education Landscape \& the FPCU Sector}

The current climate of the FPCU sector and higher education as a whole can be explored through the lens of public policy. Historically, federal policy on higher education shapes how students, parents, and academe behave; this remains true in today's climate. The U.S. government has a relationship with higher education by the very policies that are implemented. In her book Degrees of Inequality Suzanne Mettler (2014) addressed the U.S. higher education system and concluded that the failure of federal public policy upkeep is a considerable element of the current higher education landscape. In particular, Mettler (2014) pointed to the U.S. government's role in questionable higher education funding policies and lack of "policy maintenance" (p.160) which directly resulted in the growth of the for-profit industry. Between 1980 and 2011, the cost to attend a public four-year university has increased $244 \%$, thus putting the burden of cost on families and students.

Metter (2014) attributed three points centered on higher education funding that can explain how policy influences the higher education outlook. First Mettler (2014) stressed how the Pell Grant, which is aimed to assist poor students, has not kept pace with the value of increasing tuition rates. As a result, students must borrow more funds to pay for their education (Mettler, 2014). Also, with the consistent pattern of decreased state funding for higher education, families must also borrow more or use alternative methods to help subsidize the cost of attendance (cashing out of 401k, second mortgage, etc.), 
which parents did not have to do previously because college was affordable. The third and most important point is how lenient policies such as the $90 / 10$ rule has allowed forprofit schools to "capture large portions of federal aid" (Mettler, 2014, p. 10-11). I will discuss the $90 / 10$ rule in this chapter.

Similar to Mettler's work, Tressie McMillan Cottom's book Lower Ed (2017) examined how the for-profit college sector takes advantage of generous policies to flourish at the expense of the federal government, taxpayers, and the very students they serve. The pursuit of a college degree is traditionally viewed as a social good. Because of the perceived positive societal contribution, the development of higher education (land grant universities) in the United States was further helped by policies to promote the accessibility of going to college. Obtaining a college degree is for the advancement of the society (including the economy) as a whole and to help those traditionally disadvantaged gain equal footing for advancement and progress (individually and collectively). The notion of equality or inequality within an education context is critical to the current climate of higher education.

Both Mettler's and Cottom's works addressed inequality and how higher education policy exacerbates and promotes inequality. The idea of inequality is a basis for understanding the current climate of higher education, the for-profit industry, and the present study. When the above mentioned authors discussed inequality, they meant in varying contexts, one being the college degree itself and what type (tier) of school the degree was obtained from (i.e., Ivy league) and inequality also in terms of the social economic status of the degree holder (i.e., middle class). In short, both authors asserted that the higher education industry itself promotes varying degrees in terms of prestige and 
perceived quality. Yet, the for-profit industry goes one-step further in granting credentials at a more significant expense to those who need it the most.

Despite the concept of inequality and degree value, public policy continues to be the central component of the higher education industry, including the for-profit sector.

Prior to the Trump administration and the appointment of Betsy DeVos as the U.S. secretary of education, regulation and scrutiny of the for-profit college and university industry enacted by the previous Obama administration was celebrated among higher education stakeholders. Consequently, major for-profit players, including ITT Technical Institute, Brown Mackie College, and Corinthian Colleges ceased operations and/or closed down as a result of the loss of federal financial aid benefits for students. Poor gainful employment metrics, which specify if graduates are able to secure jobs and student loan repayment rates, determined if schools were flagged for not meeting the specified requirements. However, the Trump administration and the department of education under Betsy DeVos perceives the for-profit industry quite differently and views the FPCU sector as a viable option for non-traditional students. As a result, regulations that would have eradicated federal funding at poor performing schools and consumer (or student) protections that were put in place to forgive student loans on behalf of defrauded students were either eliminated or delayed (Stratford, 2017). It remains to be seen what effects will emerge with the laxness of federal regulation of the FPCU sector.

\section{Student Choice of For-Profit College}

It is evident that the for-profit market aims to reduce the access gap and offer vocational programs for job-specific occupations. Community colleges have open admission criteria, which also address the access gap within higher education in the 
United States. Baum, Kurose, and McPherson (2013) indicated that community colleges also provide vocational and job training programs; yet for-profit institutions come with an expensive price tag. To answer why students may select an expensive for-profit college rather than an affordable community college, one must consider the concept of student choice. Below, I discuss two studies centered on for-profit college choice factors. Iloh and Tierney (2014) explored the student perspective on choice, through a qualitative lens. Chung's (2012) research, quantitatively examines factors students consider to attend an FPCU. Both studies effectively contribute to for-profit higher education research specifically concerning for-profit student choice.

Iloh and Tierney (2014) conducted a case study to address the factors students consider when making the decision and discuss how rational choice and college choice theories are relevant to the decision-making process. The study, conducted in California, sampled 75 for-profit students and 62 community college students enrolled in a vocational health sciences related associate's degree program. The researchers performed interviews, surveys, and focus groups with the sampled population. Iloh and Tierney (2014) found that students have different perspectives of costs and benefits associated with college selection. For-profit students often stated that responsiveness from the forprofit school was faster and their program length was shorter as compared to a community college (Iloh \& Tierney, 2014).

For-profit students also deemed community college admissions a barrier, as opposed to the for-profit school. These restrictions include believed to be ambiguous admission guidelines, program waitlists, and course space constraints. Community college students indicated the same admission barriers but were willing to persist despite 
the obstacles. For-profit students perceived the high price of their institution worth it because of hands-on training, convenient course scheduling, and accelerated course format (program duration), whereas community college students boasted about the cost being cheaper than for-profit colleges. As a result, community college students found the price to attend for-profit schools too risky.

Iloh and Tierney (2014) provided sound and relevant reasoning for using rational choice and college choice theory to examine why students decide to attend an FPCU. They explain that rational choice theory assumes that a student will base a decision on the information they collect. The approach follows three assumptions: through rational calculations, humans decide their behavior, humans use their current life factors when making decisions, and decisions are aimed at maximizing pleasure or gain (Iloh \& Tierney, 2014). The researchers also discuss how college choice theory, as defined by Hossler and Gallagher (1987, as cited by Iloh \& Tierney, 2014), includes three phases: predisposition, search, and choice. In conjunction with these two theories, Iloh and Tierney (2014) conducted a qualitative study encapsulating the student perspective, which provides a solid foundation to understanding why and how students decide to attend an FPCU as compared to community college students. They found that there is no clear-cut answer. Students conduct their own cost and benefit analysis on which to base their decisions, including time constraints and other expenses. However, it is important to note that the accelerated program feature was a recurring theme when deciding to enroll at a for-profit college. Other factors including school proximity, perceived institutional quality, expected salary, and job outcomes were also noted in the study. 
Regarding outcomes, it would be insightful to conduct a follow-up study with the for-profit study participants to gain additional insight on the returns of their degree. However, separate studies examining the returns of for-profit attendance are discussed later. The authors of the study also contend that a longitudinal study exploring the same sample participants after graduation would be beneficial (Iloh \& Tierney, 2014). Although rational choice is a sound framework for understanding for-profit college attendance, I agree with the researchers that it is perhaps too restricted to individual preferences. Other institutional factors, such as accreditation, could play a role in student choice. Iloh and Tierney's (2014) study provided a snapshot of why FPCU students chose for-profit schools over community colleges.

Chung's (2012) study also explored the reasoning behind for-profit college choice; she investigated whether students self-selected into FPCUs or if external factors such as tuition pricing or accidental circumstances were relevant factors. Chung (2012) also employed college choice theory as the framework for the study but applied it as a quantitative model, random utility model, in which students would "maximize their utility" (p. 1087). The model included four alternatives sample participants could choose from: no college, an FPCU, a two-year college, or a four-year college. Rather than sample currently enrolled students, like in the Iloh and Tierney (2014) study, Chung (2012) used for-profit student datasets from the National Education Longitudinal Study of 1988 and the 2000 Postsecondary Education Transcript Study. This data was made available through the National Center for Education Statistics, U.S. Department of Education. The sampled population were eighth-grade students in 1988 with follow-up surveys conducted in 1990, 1992, 1994, and 2000. In addition to surveys, students were 
interviewed along with their parents, teachers, and school administrators (Chung, 2012). Below I address college choice factors from Chung's (2012) study including gender, race, age, costs and financial aid implications of for-profit college selection and compares the findings to other empirical studies.

\section{Gender}

Chung (2012) found gender to be a significant component of for-profit choice; over $60 \%$ of for-profit students were women, which is consistent with the current research on FPCU student demographics. Deming et al. (2013) reported that $65 \%$ of FPCU students are women. Arbeit and Horn (2017) found that $60-76 \%$ of enrolled undergraduate students are women compared to $54-57 \%$ at public non-profit colleges. Interestingly, Chung (2012) mentioned that the "majority of for-profit female students concentrate in low-paying vocations, such as health professions, personal and culinary services and business support," (p. 1092) in which are industries FPCUs often specialize. Similarly, the Iloh and Tierney (2014) study focused on students within the health field, and women represented over $50 \%$ of the for-profit student sample, which is a distinct and consistent trend within the FPCU student demographic.

\section{Race}

Surprisingly, race was not a significant component regarding for-profit choice, according to Chung (2012). The study found that minority students (in the sample) were five percent more likely to attend four-year non-profit institutions, which differs from the literature. Deming et al. (2013) reported that $22 \%$ of FPCU students are AfricanAmerican, while Arbeit and Horn (2017) found 22-27 \% of FPCU students are Black compared to $13-16 \%$ at non-profit schools. Within the Iloh and Tierney (2014) study, the 
majority of the FPCU sample were Latino and Black. With the high majority of proprietary institutions enrolling minority students, Oseguera and Malagon (2010) studied the college choices of Latina/o students. Oseguera and Malagon (2010) used data from the National Center for Education Statistics (NCES) in conjunction with Perna's college choice model to uncover factors for Latina/o students electing for-profit institutions. Using empirical methods, Oseguera and Malagon (2010) concluded student interaction with high-school counselors could be used as a predictor to determine student choice in higher education. Consequently, Oseguera and Malagon (2010), concluded that counselors tend to steer Latina/o students "towards for-profit colleges" (p. 84).

Garrity, Garrison, and Fiedler (2010) noted that for-profit enrollment of Black, non-Hispanic students increased significantly (19\% in 2004) considerably higher than in non-profit institutions. Hispanic student enrollment also increased in the for-profit sector (up 19\% in 2000), but unlike with Black students, there was a 17\% decrease by 2004 . The decrease in Hispanic enrollment at for-profit colleges was caused by increases of Hispanic students at non-profit institutions (nine percent increase in the private non-profit sector and $11 \%$ increase by public non-profit IHEs). Sheldon (2009) conducted a study using logistic regression to determine the predictors of why students transfer to for-profit institutions in California. Sheldon (2009) concluded that African-American students were likely to transfer to for-profit institutions even though they qualified for admission at selective colleges. However, because of limitations in the study, the researcher was unable to find a correlation with federal financial aid as a factor to transfer to a proprietary institution (Sheldon, 2009). Boykin (2017) affirmed that FPCUs have the 
largest share of minority students except in those colleges classified as minority-serving institutions, including historically Black colleges and universities (HBCUs).

Age

Chung's (2012) research found that students who enroll in FPCUs do so right after completing high school, which is not in congruence with the current literature. Boykin (2017) described the FPCU student profile as age 27, female and ethnic minority, married with children, under full-time or part-time employment while enrolled. Deming et al. (2013) stated that FPCU students are "disproportionately older," of which $65 \%$ are age 25 or older (p. 139). Arbeit and Horn (2017) contended that military students are a significant portion of the four-year for-profit market. However, Chung (2012) indicated that of those students who matriculated into an FPCU, they did so right after high school. Chung (2012) explained that they self-selected into an FPCU, indicating that for-profit enrollment was not accidental. These students were found to have low non-cognitive skills, low parental involvement regarding their academics, and fewer family resources than students in traditional non-profit colleges (Chung, 2012). Although the findings are not representative of what the literature contends, they are significant to the discussion. It is understandable that younger students with less parental guidance may select an FPCU, as opposed to a community college.

\section{Costs}

Chung (2012) mentioned that the sample participants considered cost as a factor but not to the extent of the sample participants from the Iloh and Tierney (2014) study. For example, Chung (2012) found that an increase in community college tuition increases the probability of students selecting a for-profit institution by one percent. At first glance, 
this may not seem like a significant effect. However, Chung (2012) explained that the perception of for-profit colleges and community colleges are not interchangeable among sample participants. Therefore, the increase in tuition at the community college was not deemed worth it to sample participants from the Chung (2012) study. The participant perspective in Chung's study is aligned with some of the sample participants from the Iloh and Tierney (2014) research, in that the FPCU students perceived greater institutional quality at the for-profit college than at the community college.

A notable limitation of the Chung (2012) study was that financial aid resources, academic majors, and institutional characteristics were not considered in the choice model. Therefore, the results do not contain a substantive rationale that can be applied to multiple student demographics. Some of Chung's (2012) findings such as gender, race, and age, were not represented in the current literature. However, the results do add to the discussion for students matriculating into FPCUs right after high school.

Although the Iloh and Tierney (2014) study differed from Chung's (2012) research in methods (qualitative versus quantitative), both works used college choice theory to frame their approach. Each study scrutinized varying factors affecting student decisions. In addition, both studies considered the community college alternative as a substantial component in their analysis. The findings of each study contributed to understanding why students choose to attend an FPCU and what variables they consider when doing so. Another primary element within the FPCU discussion centers on the financial aspect, which requires further analysis. Below, I present research studies that address components of financial assistance of the for-profit sector. 


\section{Financial Aid}

Concerning student choice and cost, tuition prices and financial aid resources are a significant factor in determining FPCU student choice. With available financial resources (grants and loans), students would be able to pursue higher education, thus increasing access to higher education opportunities. However, rising tuition costs within the traditional non-profit higher education market have steadily grown faster than the rate of inflation (Ma, Baum, Pender, \& Welch, 2016). The trend in tuition pricing led to policy aimed at addressing tuition prices. In 2008, the Higher Education Opportunity Act was passed to keep college affordable by examining why and what is causing tuition costs to increase.

Nevertheless, with decreasing state appropriations, public and private non-profit colleges experience annual tuition hikes and students are mainly priced out of educational opportunities, especially the academically disadvantaged student (Lynch, Engle \& Cruz, 2011). However, decreased state funding and the rising tuition costs, may have a direct effect on the for-profit industry, which offers programs almost five times higher than the tuition rate at public non-profit institutions (Darolia, Koedel, Martorell, Wilson \& PerezArce, 2015). Cellini and Chaudhary (2014) reported about 90\% of FPCU students assume loans to pay for their education and these loans average $\$ 7300$ per year, which is the highest among the three sectors of higher education. Considering the persistence of the for-profit market, the following studies explore how federal financial aid influences FPCU student choice.

Stephanie Riegg Cellini's (2010) work on federal financial aid and the for-profit education sector provides a significant view on how aid influences for-profit student 
enrollment. Cellini (2010) obtained data from a myriad of sources including: the California Bureau of Private Postsecondary and Vocational Education, California Community Colleges Chancellor's Office, U.S. Department of Education's Office of Postsecondary Education, U.S. Department of Veterans Affairs, California Postsecondary Education Commission, Rand Corporation California, California Department of Finance's Statistical Abstract, and the U.S. Census Bureau Small Area Estimates. Using data from these agencies mentioned above, Cellini (2010) considered public appropriations for sub-baccalaureate education, for-profit college data in California, community college enrollments, Pell Grant and GI Bill statistics, Cal Grant data, and population and poverty data to evaluate how financial aid programs affect the two-year college education market. An economics framework of college supply and demand was applied to the study. Cellini's (2010) study concluded that except for the GI Bill, grant aid programs do encourage entry into for-profit colleges and universities.

Cellini's (2010) research served as a solid foundation to consider and expand the research to the four-year higher education market. It is understandable to explore the effects within the two-year education market because both the for-profit and community college sectors provide similar academic programs. It would be interesting to gain insight regarding the four-year college sector. Applying economic concepts, like a supply and demand framework, helps the reader understand that the market for for-profit education has maintained because of the demand. Students choose FPCUs because there is aid available to them. For students wanting to pursue a program in an emerging field such as information technology, for-profit institutions seem to provide what the community 
college does not offer, as the for-profit sector can quickly adapt to labor market demands (Cellini, 2010; Gilpin, Saunders \& Stoddard, 2015).

The results of Cellini's (2010) study, although not applicable on a national perspective, is relevant to regional areas with a strong FPCU market. States offer varying grant aid packages and prioritize higher education funding differently. While some states provide generous grants, other states may not prioritize the community college in the same manner, as does California. However, the findings are significant, as they answer the question whether aid encourages enrollment. Nonetheless, the study neglects the student loan and debt factor, which would address how FPCU choice is affected by tuition price and loan debt. Further, Cellini's (2010) study notes that rising tuition costs and financial aid packages influence FPCU student choice.

Garrity et al. (2010) examined how Pell Grants influenced the expansion of the FPCU market. Pell Grants or, need-based grants, provide additional information required to achieve a holistic view of students who enroll at for-profit institutions. Considering the for-profit student profile, Macqueen (2012) claimed that FPCUs attribute high student default rates to the demographic they serve, citing that the "disadvantaged student" is overrepresented in the high student loan default rates (Heller, 2011; Macqueen, 2012). Garrity et al. (2010) considered both the two-year and four-year higher education market within the FPCU and traditional non-profit sectors and found that FPCUs receive a more substantial portion of Pell Grants as compared to conventional non-profit institutions, while also spending fewer resources on instruction. With FPCUs obtaining a larger portion of Pell Grants significant may shed light into how for-profit schools can provide 
academic resources at a cheaper cost than traditional institutions (this increases scrutiny, questioning instructional quality within the FPCU sector).

Belfield (2013) used data and reports from the U.S. Department of Education, on institutional loans, repayments, and defaults, while considering student characteristics. Belfield (2013) found that repayment rates and graduation rates are low for those institutions with a high number of minorities. Belfield (2013) concluded no racial correlations to loan repayments could be found in his study, but that high loan balances existed for students from the two-year and four-year for-profit institution. For the public non-profit institution sector, Belfield (2013) confirmed, "students in the public system borrow the least and students in the for-profit system borrow the most" (p. 15). Although Belfield's (2013) research does not explicitly focus on FPCU student choice, the results provide insight of the student loan and debt variable. Therefore, an important question to ask would be whether or not FPCU students are aware of the increased debt they may incur.

Cellini's (2010) study focused on the for-profit and community college sector in California from 1989 to 2003. Cellini’s (2010) research supported the notion that federal financial aid resources expand access to higher education. Few studies have been conducted regarding grant aid applied to the for-profit institution sector, as also noted by Cellini (2010). Belfield's (2013) study encompassed how loans and repayment rates affect the FPCU student. These studies address the access and choice perspective of forprofit education. However, much attention is focused on the overwhelmingly high student default rates from for-profit institutions. According to Macqueen (2012), of the $11 \%$ of students enrolled at for-profit IHEs, these students also represent $43 \%$ of the national 
student default rate. With such high student default rates, increased scrutiny into the forprofit sector has led to additional regulations on the overall higher education market, such as the gainful employment rule.

\section{Gainful Employment}

In response to high student default rates along with low graduation rates, leaving for-profit students in poor financial shape of repayment, the U.S. Department of Education authorized the "gainful employment" rules, in 2014. Gainful employment regulations are additional requirements applied to all federal aid receiving institutions, which offer vocational programs intended to lead the student to a specific occupation (Heller, 2011). The rules are designed to impose restrictions towards the for-profit sector. The requirements specify that postsecondary degree programs could lose federal financial aid eligibility if graduates are unable to repay their loans, especially if their loans exceed $12 \%$ of their total annual earnings (Darolia et al., 2015). As reported by Kreighbaum (2017), large for-profit schools, including ITT Technical Institute, Sanford-Brown, and the Art Institutes were among those who did not meet gainful employment rules and as a result, financial aid resources were not granted to new students attending these schools (Kreighbaum, 2017). As a result of not meeting "gainful employment" metrics, ITT Technical Institute filed for bankruptcy and ceased operations in 2016.

What happened with ITT Tech and other for-profit institutions because of federal policies intervening is clear evidence that the for-profit industry exploits students who attend them under the guise of providing educational opportunities. Therefore, for-profit researchers should consider the policies associated with FPCU regulation in conjunction 
with the outcomes of FPCU graduates. Researchers should also consider strategies traditional institutions can employ to assist FPCU students.

\section{Outcomes and Returns of FPCU Students}

To gain a better understanding of the FPCU sector, it is critical to understand who attends FPCUs and why, including factors students consider when making that decision. However, the research cannot and should not end there. It is equally important to address what happens to these students after they graduate. Were they able to secure employment or promotion? Did they experience significant wage growth? The research naturally steers towards worth and value of the for-profit credential. What are the outcomes of the FPCU degree? Was the degree worth it? There are substantial studies that investigate the results of FPCU graduates. Below, I discuss the research examining the labor market returns of for-profit education (mainly wages) and briefly address two engaging studies that consider the employer perspective on the value of for-profit education.

Cellini and Chaudhary (2014) conducted a quantitative study to determine the returns of for-profit college enrollment within the associate degree stratum. The author's purpose of the study was to evaluate for-profit institution quality (value) by measuring the earnings of associate degree recipients. Cellini and Chaudhary (2014) considered the associate degree segment of for-profit education. The for-profit sector confers $21 \%$ of all associate degrees across the three higher education sectors (public non-profit, private non-profit and private for-profit higher education), yet the for-profit industry enrolls "11 percent of all postsecondary students" (Cellini \& Chaudhary, 2014, p. 126).

Cellini and Chaudhary (2014) exclusively focused on students who attended

either a two-year or a four-year for-profit institution and compared them to students with 
no postsecondary education. Cellini and Chaudhary's (2014) method narrows the focus solely on the returns of the for-profit sector to determine the benefits of attending a forprofit school. Using a cross-sectional regression model, the Mincer model, Cellini and Chaudhary (2014) conducted their study using data from the 1997 National Longitudinal Survey of Youth (NLSY97). The researchers sampled for-profit students from 1997-2010 and found that students who enroll at FPCUs achieve gains of 10 percent more than those with no postsecondary credentials. The limitations of Cellini and Chaudhary's (2014) study focus on the data. The authors noted how young the sample population was, "less than 1 percent of the sample participants are at least 30 years of age" (Cellini \& Chaudhary, 2014). The age factor in their study, is a significant limitation, considering that the average age of for-profit students is in their late twenties. Another limitation of the study was that the study encompassed students who attended rather than graduated from an FPCU, which further strengthens the notion of the for-profit research neglecting FPCU graduates. However, the authors note that they emphasized FPCU student attendees rather than graduates because of their methodological approach and that accounting for FPCU graduates was an effect of outcome rather than causal (Cellini \& Chaudhary, 2014).

Denice (2015) also investigated for-profit education outcomes using the same data as Cellini and Chaudhary (2014), the National Longitudinal Survey of Youth 1997. Rather than adopt the Mincer model, Denice (2015) employed the Ordinary Least Squares (OLS) model to evaluate the relationship between academic achievement and income and found that for-profit associate degree graduates earn fewer hourly wages than associate graduates from public and private non-profit colleges do. There was no 
significant variation between high school graduates and for-profit associate degree graduates, meaning there were no positive returns for individuals completing (or attending) an associate level FPCU program compared to individuals who only earned a high school diploma (Denice, 2015). Denice's (2015) research assumed stronger significance than Cellini and Chaudhary's (2014) work because the study considered students who completed a postsecondary credential and was not limited to students who merely attended a postsecondary institution. Denice (2015) also analyzed the returns of bachelor degree recipients across the three higher education sectors and found that the for-profit student population benefits and earns positive returns.

Chung's (2008) study on for-profit college earnings used data from the National Center for Education Statistics: National Education Longitudinal Study from 1988 - 2000 (NELS: 2000) and the Postsecondary Education Transcript Study (PETS: 2000). Chung (2008) noted that the data was well suited to determine the outcomes of for-profit attendance because the information included rich detail pertaining to students' labor market experiences in addition to the descriptive material surrounding a students' family. Further, the data contained "transcript-reported, rather than self-reported, data on student's college-going and their postsecondary credentials" (Chung, 2008, p. 1). It is important to note that Chung (2008) included the word credentials to signify that the research involved FPCU and non-profit graduates and not just attendees, in contrast to the Cellini and Chaudhary (2014) study. In fact, the sample participants included in Chung's (2008) study included students across all three sectors of higher education, similar to the Denice (2015) study. The Cellini and Chaudhary (2014) study addressed only two-year associate students. 
Chung (2008) evaluated sample participant income wages and unemployment rates against the backdrop of no postsecondary credential, non-profit and for-profit certificates, associate and bachelor's degrees. Like the Cellini and Chaudhary (2014) study, Chung (2008) also applied the Mincer model of regression to assess how wages and earnings are affected by the highest college credential obtained by a sample participant.

Concerning unemployment, Chung (2008) found that under the for-profit credentials group, unemployment rates for women were $6.2 \%$ higher than men. The unemployment rate between for-profit and nonprofit male credential holders was minimal, only a .3\% difference (Chung, 2008). Astoundingly, the unemployment rates between for-profit women graduates and non-profit women graduates were $9.4 \%$ against one percent, respectively. The unemployment rate of women with no postsecondary credential was $4.7 \%$; which is lower than women who have a for-profit postsecondary degree. Chung (2008) noted that the t-statistics were not significant among the for-profit and nonprofit graduates. Nevertheless, the unemployment rates of female FPCU graduates is worth noting. Interestingly, there is little variance between employment rates of males (Chung, 2008). Chung (2008) found that wages for FPCU graduates were lower than non-profit graduates but higher than individuals with no postsecondary training or credential. Finally, Chung (2008) concluded that the evidence to support FPCU recruiting and marketing pleas is false regarding job placement and employment.

The studies above addressed the outcomes and returns of attending and graduating from an FPCU. The research confirms that the returns and consequences of attending or graduating from an FPCU are poor. Cellini and Chaudhary (2014) provided a significant 
perspective and found that two-year FPCU students achieve $10 \%$ more in returns than individuals with only a high school diploma or equivalent. In contrast, Denice's (2015) study used the same data set and found that among for-profit associate degree holders there was no significant difference of returns compared to individuals with only a high school diploma. Cellini and Chaudhary's (2014) results promote the value of a for-profit credential. However, Denice (2015) and Chung's (2008) study affirm the narrative that FPCU value is questionable at best.

Within Cellini and Chaudhary's (2014) work, the results fell short of obtaining a comprehensive perspective of the actual value of the for-profit college, in that the data considered attendees rather than graduates. Chung's (2008) and Denice's (2015) research contained a better observation of the outcomes of attending and graduating from an FPCU and compared the findings against individuals with a high school diploma up to individuals with a four-year bachelor's degree. In short, Chung's (2008) and Denice’s (2015) work encapsulated a complete investigation of FPCU value and worth by measuring the outcomes.

Neither of the studies mentioned earlier on labor market returns of the for-profit sector included recommendations to remediate the poor outcomes and returns of attending an FPCU. The purpose of each study was to assess the for-profit market through the real variables such as wages, earnings, and unemployment. However, considering that the Chung (2008) and Denice (2015) studies resulted in unfavorable findings, a recommendation to educate the public or strategies to improve FPCU recruiting tactics should have been included. Further, a discussion surrounding what strategies or potential intervention methods can be implemented is appropriate. 


\section{Employer Perspectives of For-Profit Higher Education}

Relevant to the discussion of the outcomes of FPCU student credentials and training, two studies considering the employer perspectives of FPCU credentials are addressed. Darolia et al. (2015) conducted a field experiment using fictitious resumes to evaluate employer preferences of job applicants. Excluding nursing, the researchers submitted resumes to occupations similar to for-profit sub-baccalaureate programs such as information technology and medical assisting (Darolia et al., 2015). The results indicated no preference for for-profit applicants, in comparison to non-profit public applicants and high school graduates. Comparatively, the authors found that employers preferred community college applicants (Darolia et al., 2015).

Deming et al. (2016) conducted a similar experimental study using fictitious resumes. The difference here is that Deming et al. (2016) did their study limiting their occupational categories to business and health fields and expanded the for-profit credential to include bachelor's degrees. The results of the Deming et al. (2016) study found that for-profit business bachelor's degrees and for-profit health certificates were less likely to receive employer call-backs and that there is "no evidence to support that for-profit credentials will improve the job prospects of workers who would otherwise not attend college at all” (p. 804). Deming et al. (2016) concluded that employers may view the for-profit credential negatively and that the consequence of FPCU attendance can be interpreted as disadvantageous. The results from the study do not vary from the Darolia et al. (2015) findings and further demonstrate that FPCUs may not be worth the price-tag, considering their target population is disadvantaged students with limited financial resources. 


\section{FPCU Student Experiences}

Iloh (2016) conducted a qualitative study on the experiences of for-profit students and found that students long for clarity regarding institutional decisions and policies (i.e., re-accreditation, scholarships); enjoy class time and make strong connections with their faculty; encounter multiple perspectives from their course offerings, and experience agerelated maturity concerns in their courses. Iloh (2016) encompassed an ethnographic approach to collect and observe data from 21 students attending a for-profit college in California. Iloh's (2016) study explored institutional culture, student experiences and implications of attending an FPCU, and serves as a foundation for future research in the arena of FPCU student experience and perspective (Iloh's, 2016). One recommendation worth noting from Iloh's (2016) study is the perception of business processes and transparency. For-profit college students appreciate clarity and information regarding their institution, such as the case regarding re-accreditation. Iloh (2016) indicated that the failure to communicate the accreditation status of the school was a missed opportunity for clear communication, according to the students. Students desire transparency, which is a sentiment that can be expressed throughout all higher education sectors. However, it is significantly more important for the FPCU, considering the negative clout surrounding the for-profit industry.

\section{Counter Arguments and Recommendations}

Much of the for-profit education literature encompasses the negative implications

of attending a for-profit institution. The current section discusses the literature in support of for-profit higher education and recommendations to improve the sector. Richard Hassler (2006) addressed how the for-profit market provides opportunities for students 
seeking an accelerated point of entry for a career. Hassler compared the mission statements of popular for-profit institutions and compared them to those of some prestigious universities. The point of the exercise was to demonstrate that the for-profit mission is career oriented and unlike that of traditional schools where the missions commonly promote critical thought and inquiry, research and scholarship (Hassler, 2006). Hassler (2006) does not bode this argument well, as he noted that the for-profit career placement offices present challenges in servicing both the student and employer. All postsecondary institutions experience this difficulty, as it is not unique to only the for-profit sector.

Hassler (2006) also confronted accreditation and funding differences between the for-profit sector and non-profit sectors. Hassler (2006) claimed that to receive federal funding, institutions must be recognized by accrediting bodies and that for-profit students must rely on federal aid to subsidize their education more so than students who attend public universities. The argument here is that for-profit schools generate revenue only through tuition and fees and they do not receive state appropriations or scholarship or endowed funds through donors. Therefore, the "burden" is placed on board members and administrators to both meet accreditation standards and shareholder expectations.

The 90/10 policy states that for-profit institutions are eligible to receive federal funding (Title IV funds such as the Pell grants) and can collect "no more than 90 percent of its total revenue" from federal funds. The institution must exhibit that at least $10 \%$ of revenue can be obtained from "sources other than federal student aid funds" (Heller, 2011 p. 60). The 90/10 rule penalizes institutions which exceed the $90 \%$ maximum for two consecutive years. Similar to public institutions, taxpayers support the for-profit sector. A 
key difference is that a publicly traded corporation (i.e., the Apollo Group is the parent company of the University of Phoenix) often backs an FPCU. Further, the revenue earned from federal funds can be distributed to investors as dividends. However, the research points to adverse effects of attending a for-profit institution such as high student loan debt and low returns. It is understandable to question the value of the for-profit market and scrutinize why federal funding is available if the returns and impact are so poor.

Within the research of for-profit higher education, the student perspective is largely ignored. Studies addressing for-profit choice, the financial aid factor, and outcomes are prevalent. Studies examining the for-profit attendance and student experience resulting in a for-profit credential are almost non-existent. Iloh's (2016) ethnographic research on the for-profit student experience is relevant but does not capture the culminating student experience. The FPCU graduate perspective is valid and requires attention. The interpretation of their experience at a for-profit college may indicate overlooked aspects of the for-profit higher education sector. 


\section{CHAPTER III}

\section{METHODS}

This chapter describes the methodology I used to explore three components of students who attended or graduated from for-profit institutions: the choice/decision making process, the student experience, and outcomes upon degree completion from a for-profit college or university within the South Florida region. My study is guided by the education gospel framework, which is the belief that education and the pursuit of educational credentials will result in social and economic mobility (Grubb \& Lazerson, 2004). The framework postulates that the pursuit and process of college education prepares students for the labor market, resulting in employment (Grubb \& Lazerson, 2004). Students who attend college do so with the goal of obtaining a degree, which has proven to provide access to employment, additional credentials, and other socioeconomic opportunities. Historically, higher education in America during the $16^{\text {th }}$ and $17^{\text {th }}$ centuries was limited to young white males seeking opportunities for self-exploration and curiosity. The student demographic then is in stark contrast to the modern-day college student. However, along with the notion of the American Dream, the education gospel persists and has been perpetuated throughout the education system in the United States.

Chapter Three addresses the rationale for a qualitative study. It also includes a description of the participant selection criteria and the recruitment process. I conclude with a detailed discussion of the data collection and analysis process, including data integrity measures and limitations. 


\section{Rationale for Qualitative Research}

I conducted a qualitative study to understand and describe the experiences and outcomes of students who graduated from for-profit colleges and universities. I wanted to explore the FPCU student experience directly from the source. My goal was to understand and report how students came to the decision to obtain a degree and why they decided to do so. Uncovering their motivations for a college degree seemed to be a substantial component of their process. I also desired for the participants to describe what was going on in their lives during their decision-making phase. I specifically wanted the participants to tell their stories. A qualitative study would result in the participants describing their journey from the onset of their commitment throughout their entire academic process, and post degree completion.

Further, the present qualitative study addresses the academic journey of a neglected population - FPCU graduates. In their own words, the current study stresses the importance of post-secondary education to adult learners and working individuals (non-traditional students). I explored the FPCU student experience in chronological order and found that the respondents were eager to share their stories. Qualitative inquiry highlights the participant narratives. The in-depth examination results in knowledge about the motivations, successes and overall culmination of the FPCU graduate experience.

The purpose of the present study is to explore the perceptions and experiences of FPCU students. This study is interpretive in nature and I am specifically interested in understanding the how and why questions related to this student demographic. Utilizing a constructivist paradigm, I value the experiences of participants and depended on 
"participants" views of the situation being studied" (Creswell, 2003, p. 8) Further, applying a constructivist approach, I intended to "generate or inductively develop a theory or pattern of meanings" throughout the research process (Creswell, 2003, p. 9).

Merriam (2002) summarized significant characteristics of qualitative research.

First, qualitative research aims to "understand the meaning people have constructed about their world and their experiences" (Merriam, 2002, p. 4-5). Secondly, the researcher serves as the primary instrument for data collection and analysis and using an inductive approach the outcome is typically descriptive (Merriam, 2002, p. 5). Therefore, a qualitative study is applicable under the considerations of the research questions listed below.

\section{Research Questions}

1. Why did students FPCU graduates chose to attend a for-profit college?

2. What were the experiences of FPCU graduates in college?

3. What were the FPCU graduates' experiences upon completing their degrees?

\section{Role of the Researcher}

This study examines the decision-making process, the experience and outcomes of individuals with an earned academic credential from a for-profit college in the South Florida region. As a higher education professional, I have worked with individuals who have attended an FPCU, graduated from an FPCU, and/or been employed at an FPCU. The perspective from these individuals varies as it pertains to their specific end-goal. Therefore, it is essential that I understand my role as a researcher.

I first came to learn about for-profit universities during my tenure as an academic advisor. Unfortunately, during my tenure, I often communicated to prospective and 
transfer students that the institution would not accept earned FPCU credits or validate an FPCU degree. Most of these prospective students graduated with an associate's degree from select local for-profit schools that were not regionally accredited. The students were eager to continue their education at a state university for a bachelor's degree. At first, I had not heard of these for-profit schools, such as College of Business Technology or ATI Career Center. As I spent more time in this role, I noticed that there were repeated patterns of about five or six institutions from which prospective students attempted to transfer their credits. It was during this time when I recognized that certain for-profit colleges were profiting off students who would not be able to utilize their degree or transfer credits to an accredited university.

Outright denying admission or admitting FPCU students without accepting transfer credits seemed harsh to me. However, as I learned more about the for-profit sector, I realized that some students benefit from their degree and others might struggle as a result, post-graduation which is similar to the traditional graduate experience. However, the main difference I noticed was that for-profit students were always very surprised when informed that their credits were non-transferrable or their degree was from an unaccredited institution.

These unfortunate observations developed into curiosity that sparked my interest of the for-profit sector. As I began to learn more about proprietary institutions, I found myself wanting to understand more about for-profit students and their experiences. I wanted to understand how they, the students, learned of these schools and what led them to decide to attend a for-profit school. In addition, I desired to uncover if they themselves understood and knew the difference between a public or private non-profit institution and 
for-profit colleges. I sought to understand why they did not know that these colleges were exploiting students.

My experience as an advisor exposed me to a completely new aspect of higher education. I was ignorant of how prevalent this industry is. More importantly, I sympathized and empathized with the FPCU graduates and transfer students, who would essentially have to restart their post-secondary education if they wanted an accredited credential. It seemed unfair that this could happen and I wanted to understand the prevalence of the for-profit industry and the students that graduate from for-profit colleges. As I continued my research on the for-profit industry, what became clear to me is that there were limited reports of the for-profit student experience and far less of the completed FPCU graduate experience. Therefore, in consideration of this study, I developed the following participant selection criteria.

\section{The Participants}

I identified and selected 12 participants who met the following criteria. Individuals who qualified, include students with an earned a post-secondary degree between the year 2009 through 2019 from a for-profit institution in the South Florida region. I sought individuals who graduated from the University of Phoenix, DeVry University, Everglades University, College of Business Technology, Everest College, Miami Regional University, Florida National University, The Art Institute of Ft. Lauderdale, The Art Institute of Miami, Florida Career College, Florida Technical College, Miami International University of Art \& Design and South University. Alumni within this timeframe may have had varied experiences, considering the implemented 
regulation of the for-profit industry by the Obama administration from 2008-2016 in contrast to the current de-regulation attempts by the Trump administration.

The study selected graduates from the institutions mentioned above in the South Florida region, because of convenience and due to the plethora of private for-profit schools in the geographical region. All participants were required to have graduated from a for-profit college one of the institutions, to ensure that all participants have some collective shared experience and can describe the decision-making process and experience as an FPCU student. Graduates or alumni of an FPCU can provide a detailed comprehensive account of their experience, including the results of obtaining a credential or degree. I limited the study to the last 10 years for accuracy and memory. Participants are likely to recall their experiences clearly and accurately if the occurrence can be captured in recent memory. I noticed that participants who graduated in 2009 struggled to remember the enrollment process with clear detail.

\section{Participant Recruitment and Access}

To conduct the study, I obtained approval from the Florida International University Institutional Review Board (IRB). I received access and permission from the research participants through purposeful sampling and snowball sampling. I was able to recruit participants through the use of social networking platforms such as LinkedIn, academic and professional referrals, and personal solicitation. I posted an IRB approved recruiting flyer on social media platforms including Facebook, Instagram, and LinkedIn.

I was able to secure 26 potential participants in total. Eighteen individuals out of the 26 were obtained through my higher education professional network; a potential participant referred the remaining eight individuals. Out of the 26 potential participants, 
15 individuals responded favorably to participate in this study. Of the 15 willing individuals, 12 were eligible to participate. Two individuals were not eligible; one potential participant did not yet complete their degree requirements from an FPCU and the other two potential participants graduated prior to 2009 .

I screened each respondent for eligibility criteria, meaning that participants had to have graduated from an FPCU in the South Florida region or resided in the South Florida region while they attended an FPCU in-person or online. I conducted the screening process via in-person meetings, telephone conference, and Skype/video conferencing and took approximately 5-10 minutes. I enacted the screening process to establish rapport with each potential participant and to provide informed consent. The purpose was to provide transparency and to develop a connection with each participant. Please see Appendix A for more information on the screening questionnaire. During this phase, respondents were evaluated for participation eligibility and provided the informed consent form. I scheduled a follow-up interview if participants were eligible.

\section{Participant Profiles}

A purposeful sampling method resulted in 12 research participants. The objective was to obtain a diverse sample, including both male and female respondents. However, the participant sample included one male and eleven females. The gender disparity represented in this research study is likely due to the primary method of participant referrals. However, the research on for-profit colleges and universities indicate that women represent over $60-65 \%$ of enrolled FPCU students (Chung, 2012; Deming et al., 2013). Participants referred their colleagues and/or friends to participate in this study and the initial participants are women who essentially referred other women. 
The average age was expected to be approximately 30 years of age since enrollment data demonstrates FPCU students are typically older than traditional first-time in college students (Boykin, 2017). The participant average age was 38 at the time of the study. However, the participant average age while enrolled as a for-profit college student was 32 years of age. One participant is considerably older than the sample of participants. The participant's age skewed the average age higher than expected.

The participant demographics included individuals who identify as Black/AfricanAmerican or White-Hispanic. Research on for-profit institutions indicates student enrollment representation includes first-generation students and minority students who are traditionally underrepresented in non-profit universities (Boykin, 2017). The represented sample in this study supports the research, as the study participants identified as either African-American or Hispanic.

The majority of the research participants maintained full-time employment while enrolled at the for-profit college. Seven research participants hold careers in the higher education/college administration industry. Two participants hold positions within the banking and accounting field. For the remaining three participants, one participant works within the healthcare management field, one participant is an attorney, and one participant works for a real-estate investment company.

The research participants earned associate degrees, bachelor's degrees, and master's degrees from various for-profit colleges and universities, including large national institutions such as the University of Phoenix and DeVry University. The study respondents graduated from the years 2009 - 2019. I present a summary of the participant demographic data including the earned FPCU degree information in Table 1. 
Table 1

Participant Summary Table

\begin{tabular}{|c|c|c|c|c|c|c|}
\hline Participant & $\begin{array}{l}\text { Age } \\
\text { Range }\end{array}$ & Gender & Race/Ethnicity & $\begin{array}{l}\text { Degree } \\
\text { Level }\end{array}$ & Year & FPCU \\
\hline Kate & $\begin{array}{l}35- \\
40\end{array}$ & Female & White/Hispanic & $\begin{array}{l}\text { Associate } \\
\text { Bachelors }\end{array}$ & $\begin{array}{l}2009 \\
2014\end{array}$ & $\begin{array}{l}\text { Brown Mackie College } \\
\text { Argosy University }\end{array}$ \\
\hline Sara & $\begin{array}{l}30- \\
35\end{array}$ & Female & White/Hispanic & Bachelors & 2014 & DeVry University \\
\hline Tiffany & $\begin{array}{l}35- \\
40\end{array}$ & Female & $\begin{array}{l}\text { Black/African- } \\
\text { American }\end{array}$ & $\begin{array}{l}\text { Associate } \\
\text { Bachelors }\end{array}$ & $\begin{array}{l}2017 \\
2018\end{array}$ & $\begin{array}{l}\text { University of Phoenix } \\
\text { University of Phoenix }\end{array}$ \\
\hline Linda & $\begin{array}{l}40- \\
45\end{array}$ & Female & $\begin{array}{l}\text { Black/African- } \\
\text { American }\end{array}$ & Masters & 2009 & University of Phoenix \\
\hline Nicole & $\begin{array}{l}35- \\
40\end{array}$ & Female & White/Hispanic & Bachelors & 2014 & University of Phoenix \\
\hline Michael & $\begin{array}{l}35- \\
40\end{array}$ & Male & $\begin{array}{l}\text { Black/African- } \\
\text { American }\end{array}$ & Masters & 2012 & Strayer University \\
\hline Diane & $\begin{array}{l}45- \\
50\end{array}$ & Female & $\begin{array}{l}\text { Black/African- } \\
\text { American }\end{array}$ & Masters & 2011 & Strayer University \\
\hline Helen & $\begin{array}{l}55- \\
60\end{array}$ & Female & White/Hispanic & Bachelors & 2016 & $\begin{array}{l}\text { The Art Institute of } \\
\text { Miami }\end{array}$ \\
\hline Amy & $\begin{array}{l}40- \\
45\end{array}$ & Female & $\begin{array}{l}\text { Black/African- } \\
\text { American }\end{array}$ & $\begin{array}{l}\text { Associate } \\
\text { Bachelors }\end{array}$ & $\begin{array}{l}2013 \\
2016\end{array}$ & $\begin{array}{l}\text { University of Phoenix } \\
\text { University of Phoenix }\end{array}$ \\
\hline Victoria & $\begin{array}{l}40- \\
45 \\
\end{array}$ & Female & Black/Hispanic & Masters & 2010 & DeVry University \\
\hline Rachel & $\begin{array}{l}35- \\
40\end{array}$ & Female & $\begin{array}{l}\text { Black/African- } \\
\text { American }\end{array}$ & $\begin{array}{l}\text { Associate } \\
\text { Bachelors } \\
\text { Masters }\end{array}$ & $\begin{array}{l}2012 \\
2012 \\
2017\end{array}$ & $\begin{array}{l}\text { American Intercontinental } \\
\text { University } \\
\text { American Intercontinental } \\
\text { University } \\
\text { Everest University }\end{array}$ \\
\hline Kim & $\begin{array}{l}30- \\
35\end{array}$ & Female & $\begin{array}{l}\text { Black/African- } \\
\text { American }\end{array}$ & $\begin{array}{l}\text { Associate } \\
\text { Bachelors } \\
\end{array}$ & $\begin{array}{l}2010 \\
2013\end{array}$ & $\begin{array}{l}\text { Brown Mackie College } \\
\text { DeVry University }\end{array}$ \\
\hline
\end{tabular}

In total, the study participants earned 23 post-secondary credentials, with 18 degrees being from an FPCU. Out of the 18 earned degrees, 11 are within a business academic discipline such as accounting, human resources, and business administration. I present a summary of earned FPCU degrees by majors/academic discipline in Table 2.

Table 2

FPCU Degree Summary

\begin{tabular}{|l|l|}
\hline Number of Degrees & FPCU Degrees By Major \\
\hline 11 & Business or business-related field (accounting, human resources) \\
\hline
\end{tabular}




\begin{tabular}{|l|l|}
\hline 2 & Public Administration \\
\hline 2 & Health Management \\
\hline 3 & Other (Interior Design, Education, Psychology) \\
\hline
\end{tabular}

Note: There is one degree each for Other (Degrees by Major).

Business degrees represent a majority of the earned FPCU degrees. In addition, the University of Phoenix and DeVry University account for the two largest represented for-profit colleges within the current study. Interestingly, both institutions are two of the largest and well-known for-profit colleges nationally. In addition, business related degrees are among the most popular degrees awarded from both the University of Phoenix and DeVry University. However, other academic disciplines such as health management and public administration are favorable majors among the research participants.

\section{Data Collection}

Data collection refers to how the researcher will obtain and gather data to answer the research questions posited. Per Merriam (2009), "Qualitative researchers are the primary instruments for data collection and analysis, interpretations of reality are accessed directly through observations and interviews" (p. 25). Informed consent was obtained from each participant. The informed consent is an essential component to the research process and provided participants with the associated risks and purpose of the study. The informed consent form also emphasized that participation was voluntary and that anonymity and confidentiality measures would be set in place. During the data collection process, I informed the participants that I would not include identifiable information and would use pseudonyms to protect their identity. 
To foster rich detail and a climate to allow the respondents to fully express their thoughts within the data collection stage, an interview schedule was used during the indepth interview. Per Smith et al. (2009), the purpose of using an interview schedule is to facilitate the discussion that allows the research questions to be answered as thoroughly as possible. The vital component of this process is that it is participant-led with some steering from the researcher. According to Smith et al. (2009), the researcher should exercise caution and always consider the research questions to determine if a focus group method is suitable. Therefore, semi-structured interviews are the primary form of this study's data collection process.

In developing the questions for the semi-structured interview, I used Iloh and Tierney's (2014) interview schedule from their qualitative study examining for-profit choice as a reference point. Please refer to Appendix C for the interview schedule utilized for this dissertation. The interview questions from Iloh and Tierney's (2014) study focused on the motivations of for-profit choice with currently enrolled students. Therefore, Iloh and Tierney's (2014) interview questions are relevant to this study's first research question: Why did students FPCU graduates choose to attend a for-profit college? As an example, the researchers asked their study's participants to indicate significant factors in choosing to attend a for-profit college (Iloh \& Tierney, 2014). A major difference between this study and Iloh and Tierney's (2014) is that their questions were centered on the present mindset of the participant. They asked the participants how they were planning to pay for their degree and if their current experience was aligned to their expectations. In contrast, the present study focused on FPCU graduates who had to recall their prior feelings and perspectives. However, like Iloh and 
Tierney's study, I too was interested in exploring the participant's pre and postgraduation expectations, as their interview schedule included post-graduation expectations (Iloh \& Tierney, 2014). I found that Iloh and Tierney's (2014) interview questions provided a suitable foundation for my study's interview schedule to help frame and understand the FPCU graduate experience from pre-enrollment throughout graduation. Please refer to Appendix B for a copy of Iloh and Tierney's interview schedules.

The in-depth semi-structured interviews aimed to capture thoughts and stated feelings of attending a for-profit college and the results of obtaining a degree. Smith et al. (2009) contend that the participants should be encouraged to speak freely to fully develop and express their perspective at length. After participants met the above stated requirements, an in-depth, semi-structured individual interview was scheduled and conducted over a five-month period with each participant.

With the research questions in mind, I asked the participants to describe their thought process at the time they considered to continue their education. The objective of this question was to have the participants paint a picture, which included their life circumstances and their motivations. I also asked the participants about their feelings when they enrolled at an FPCU. The purpose of this question was to extract how they felt the degree would assist them and help them achieve their goals. The respondents often described their feelings in terms of what their degree means to them from a personal and professional standpoint. Further, I asked the participants to describe their student experience while they were enrolled at an FPCU. I wanted to explore and have the participants describe what they liked about their institution and what could have been 
better. Having the participants broadly describe their student experience allowed for me as the researcher to make connections and observe patterns throughout the data collection and data analysis stages. I found that the participants used similar language and context to describe their experiences, especially for the participants who attended an FPCU online.

A substantial component of the interview schedule included the career and employment aspect. I asked participants to describe their employment status prior to enrolling at an FPCU, while they were enrolled as well as post-graduation. It was clear that the employment factor was a substantial element of the FPCU student perspective as most of the participant's maintained employment but were seeking career progression objectives at the time of enrollment and post-graduation.

\section{The Interviews}

The one-on-one interviews averaged about 45 minutes in length, although they were originally estimated to be one-hour. I conducted the interviews through the preferred methods of which the respondent felt more comfortable, either in person, telephone, or via video conferencing. Prior to the one-on-one interviews, I received the informed consent forms and conducted the screening questionnaire. The screening questionnaire consisted of questions to ensure that the participants met the established criteria for the present study. I proceeded with the interview schedule after participants demonstrated that they met the research criteria. The stated requirement to participate for my study included that the respondent graduated from a for-profit college or institution from 2009 - 2019 and that they resided in South Florida at the time of their study. Upon completing the interviews, I verified with each participant my interpretation of their statements and confirmed details, statements and analysis of the interview. 
The interviews with Kate, Sara, Tiffany, Nicole, and Diane were conducted inperson. The in-person interviews averaged closer to one-hour in-length and I was able to establish better rapport in the in-person interviews. I noticed that during the in-person interviews, the participants would provide more substantive information and detail regarding their experience. I did not have to prompt or ask for further elaboration during these interviews. I conducted the interviews with Kate, Sara, Tiffany and Diane on a university campus. These four participants work at the same institution and it was convenient for them to participant in the interview on-campus.

The first person I interviewed was Kate. She seemed to be shy at the onset of the interview at first but then became more comfortable as the interview continued. She spoke quietly and confidently about her experience. Kate maintained a professional and direct disposition during her interview. I found that she was the only in-person interviewee that required me to probe and ask for further explanation. Kate spoke about her experience without intonation, excitement, or displeasure. She provided a substantive account of her FPCU experience and described her experience in a direct manner.

In stark contrast to Kate, Sara's interview contained excitement and vast detail about her FPCU experience. She was the second scheduled interviewee. I conducted Sara's interview in her office on-campus. She appeared to be extremely comfortable and confident during the entire interview. Sara's eyes would light up when spoke about her FPCU institution. Sara's voice also would pitch when she described her feelings about her FPCU experience. She pointed to her degree often as she described her experience and maintained that she was proud of her accomplishment. However, when she spoke about other institutions she attended or had been employed at, her voice would lower and 
her eyes dropped. Sara confirmed her strong and positive feelings associated with her experience. She stated that she had a positive experience and advocated for her FPCU despite the industry's infamy.

Similar to Sara, Tiffany's interview was comprised of non-verbal communication. Tiffany was the third participant I interviewed. I interpreted Tiffany's facial expressions as grateful. She would often touch her chest and smile when she described her FPCU experience. Tiffany described her experience in a personal and life-changing manner. She smiled for the majority of the interview, even when she described her challenges as an FPCU student. As the interview wrapped up, Tiffany cried "happy tears" as she expressed her contentment and appreciation for sharing her academic journey.

Nicole was the fifth interviewee and I conducted her interview in her home. Her disposition during the interview was relaxed and assured. She spoke in detail about her experience and often deviated into other aspects of her experience. This was a positive attribute, as she frequently answered questions with little to no prompt from me. After Nicole would complete her account of a particular aspect she would say, "Did I answer your question?" Nicole's FPCU experience contained rich description. Like Sara, she was cognizant of her personal experience and demonstrated awareness of the common forprofit college notoriety.

Diane was the seventh participant I interviewed. Her interview was conducted in her office, on-campus. Her office did not have windows and was barely lit. During her interview, Diane's facial expression was difficult to read but not because of the lighting. However, Diane maintained a professional demeanor and demonstrated interest throughout the interview. She was adamant when I asked if she would continue her 
education; she replied emphatically that she would not seek another degree. Diane provided an adequate account of her FPCU experience. I attributed the difficulty in assessing her non-verbal communication because of her college and professional experience.

Although not an in-person interview, I utilized a videoconference program to conduct Helen's interview. She was the eighth participant I interviewed. During Helen's interview, I could view her facial expressions and body language. The video conferencing option proved to be valuable for Helen's interview. She has a strong Spanish accent and I was able to interpret her body language and facial gestures during her interview. Helen was in her apartment in Panama City at the time of her interview. I could see the view of the city and beach in the background. During her interview, I could ascertain that Helen had a relaxed disposition and encapsulated her FPCU experience with sufficient detail.

The in-person interviews provided data other than verbal accounts of the FPCU student experience. The non-verbal communication, body language and interview setting are elements I considered during the data analysis phase. The in-person interviews allowed me to establish confidence and rapport with the participants. As a result, upon completion of the in-person interviews, I received multiple referrals for potential study participants.

I conducted telephone interviews with Linda, Michael, Amy, Victoria, Rachel, and Kim. In contrast to the in-person interviews, the telephone interviews were slightly shorter in length but it was initially difficult to gauge the interest level of the participants. However, as the interviews developed, I was able to extract substantive narratives and 
conclude that the participants were genuinely interested in providing an account of their collegiate experience.

Linda was the fourth participant that I interviewed. A mutual colleague referred her to participate for the study. There were many challenges with Linda's interview. We rescheduled her original interview because she was driving home from work and there was background noise and signal interference. I heavily relied on the interview schedule for Linda's interview. She did not seem to be interested in participating in the research. I found that I had to probe and ask the same questions in different methods to obtain substantive information from Linda. Her interview was the shortest interview conducted. Linda's account could have provided further insight if it had been conducted in-person.

Diane referred Michael and he was the sixth participant I interviewed. At the onset of Michael's interview, he seemed skeptical and critical regarding the purpose of the current study. Because of his skepticism, I felt the need to reiterate the purpose of the study and cover the informed consent guidelines. After doing this, Michael's reluctance subsided and he reconfirmed his participation for the study. During his interview, Michael provided a unique account of his FPCU experience and demonstrated interest throughout the interview. After the interview, Michael and I engaged in a thoughtful discussion of the for-profit college industry.

A mutual colleague referred Amy to participate for the study. She was the ninth participant I interviewed for this dissertation. I found that Amy was polite and answered my questions with well-thought out responses. She demonstrated interest and was generally pleasant over the phone. She confidently expressed her ambitions and described 
her FPCU experience with substantive detail. Amy offered to refer my information to her colleagues to help me secure more participants upon completing the interview.

The tenth participant I interviewed was Victoria. She provided an extensive account of her FPCU experience. At the onset of her interview, Victoria informed me that she is a talker and that I could cut her off if needed. Like Nicole and Sara, Victoria's interview required very few prompts. She often answered questions within her narrative explanations. Victoria's FPCU account was unique, as compared to the other participants. She was confident in her descriptive accounts and painted a vivid picture of her process in detail.

Rachel was the only eligible participant I obtained through a professional networking site. She responded favorably to my request and we scheduled an interview after she signed the informed consent form. I administered Rachel's interview via telephone while she was at work. Initially there were a few disruptions, as her colleagues interrupted our interview. Rachel's interview contained rich voice inflection and intonation. At the start of the interview, Rachel's voice was low as she described her initial motivations for attending an FPCU. She described her comprehensive experience with affirmation. I could sense power and strength within her voice as she summarized her experiences. Further, there was anger, frustration, and disappointment in Rachel's voice when she described her post-graduation encounters and her financial circumstance.

The last person I interviewed was Kim. A mutual colleague referred her for this research study. Even though I carried out Kim's interview via telephone, I could hear and interpret her sentiment surrounding her FPCU experience. Kim's voice would rise in excitement as she talked about her initial feelings of her college experience. However, 
her tone would inflect in a somber manner when she spoke of her financial circumstances. Kim's collegiate account contained descriptive language and voice inflection. She provided a significant account of her experiences and her tonal inflection was important to the data analysis process.

All conducted interviews were audio recorded and during participant interviews, I took descriptive notes. I included phrases that the participants emphasized as well as notes indicating non-verbal cues, body language observations, and voice inflections. I secured hardcopy research documents including interview notes, informed consent forms, research memos and printed transcriptions in my personal storage container, only accessible by key. I have other analyzed data located on a password-protected computer. I conducted a preliminary review of the collected data upon completion of the scheduled interviews. This review specifically focused on shared commonalities between respondents' experiences, such as institution attended, degree, and/or demographic data.

\section{Time Schedule Upon Obtaining IRB Approval}

\begin{tabular}{|c|c|c|c|c|}
\hline $\begin{array}{c}\text { Participant } \\
\text { Recruitment }\end{array}$ & $\begin{array}{c}\text { Informed } \\
\text { Consent }\end{array}$ & $\begin{array}{c}\text { Screening } \\
\text { and } \\
\text { Interviews }\end{array}$ & $\begin{array}{c}\text { Interview } \\
\text { Transcription }\end{array}$ & $\begin{array}{c}\text { Data } \\
\text { Analysis }\end{array}$ \\
\hline $\begin{array}{c}\text { June 2019- } \\
\text { November }\end{array}$ & $\begin{array}{c}\text { June 2019- } \\
\text { November }\end{array}$ & $\begin{array}{c}\text { June 2019- } \\
\text { November }\end{array}$ & $\begin{array}{c}\text { July 2019- } \\
\text { November } \\
2019\end{array}$ & $\begin{array}{c}\text { July 2019 and } \\
\text { December 2019 }\end{array}$ \\
\hline
\end{tabular}

I administered the participant interviews over a five-month period. During this period, I recruited and interviewed each participant, and commenced the data analysis process. The data collection and data analysis process was fluid, as after I conducted the interviews I began to interpret the participant narratives. The five in-person interviews and the one videoconference interview provided more non-verbal communication to consider within the data analysis process. However, the telephone interviews required me 
to listen for subtle cues and consider how the participants articulated their experience. I also conducted member checks with each participant to ensure accuracy of their profiles and interpretations of the interviews.

\section{Data Analysis}

Data collection and data analysis in qualitative research may occur concurrently (Merriam, 2002). For example, after the first interview I adjusted the style or questioning technique. However, formal data analysis occurred after all data from interviews and observations were obtained.

I utilized a professional transcription company, Rev Transcription (found at www.rev.com) to transcribe the participant interviews. Once the transcriptions were completed, I listened to each recording and verified that the transcriptions were valid and accurate. There were minimal inaccuracies found within the transcriptions. After the transcriptions were verified, I commenced the data analysis process, which consisted of reviewing the written interview notes taken during the interviews and notes taken during the transcription verification process and proceeded to start the coding process. Upon analyzing and assessing the data, I developed codes using recurring themes, keywords, and research questions in effort to organize any emerging patterns.

After examining each printed transcript, I began the coding process. Data obtained for the study include field notes taken during each interview, research memos (taken during and after the review of interview recordings) and interview transcriptions were reviewed during the coding process. I assigned a code as patterns and regularities emerged from the data. For example, keywords such as "flexibility" and "convenience" repeatedly appeared in several transcriptions and field notes, which resulted in 
establishing the motivating factors code. The coding process resulted in 18 codes; these codes ranged from motivating factors, enrollment timeframe, purpose, outcomes, school satisfaction, and support services. I then categorized the 18 codes by the student cycle which starts with the pre-enrollment decision-making stage to the enrolled student experience phase and the post-graduation outcomes stage. This process resulted in three categories: motivation, experience and outcomes. For example, keywords such as "professor availability," and "debt" were repeatedly noted, and I assigned these codes to the experience and outcomes categories respectively. The benefits of online courses code fell under the motivating factors category because participants described this component when they were considering their options to attend an FPCU.

I recognized that the three categories were directly aligned with the research questions. As a result, the coding process which established the three categories addresses the FPCU choice perspective, the student experience, and post-graduation outcomes. The coding process took about one month and resulted in the four findings of this study.

Four major themes became evident upon completing the coding and data analysis process: Access and Choice which refers to the pre-enrollment and decision making stage of the participants; Student Support, which is described as the common thread of the student experience; Degrees of Impact and Satisfaction relates to the apparent postgraduation outcomes and to the extent to which the participants were satisfied with their academic credential; Returns on Investment refers to the perceived degree value in regards to satisfaction and the financial cost of the degree. The four emergent themes were present in the majority of the participants' narrative. Table 3 shows my coding process. 
Table 3

Data Analysis Coding Process

\begin{tabular}{|c|c|c|c|}
\hline Code & Category & Research Question & Theme \\
\hline Motivating factors/choice & \multirow{8}{*}{$\begin{array}{l}\text { Motivations } \\
\quad \text { (Pre- } \\
\text { enrollment) }\end{array}$} & \multirow{8}{*}{$\begin{array}{l}\text { Why did FPCU } \\
\text { graduates choose to } \\
\text { attend a for-profit } \\
\text { college? }\end{array}$} & \multirow{8}{*}{$\begin{array}{c}\text { Access \& } \\
\text { Choice }\end{array}$} \\
\hline $\begin{array}{l}\text { Degree Purpose \& } \\
\text { Expectations }\end{array}$ & & & \\
\hline Benefits of online courses & & & \\
\hline Enrollment timeframe & & & \\
\hline Career goals & & & \\
\hline School referral and selection & & & \\
\hline Expectations & & & \\
\hline Costs \& Financial Aid & & & \\
\hline Class Size & \multirow{6}{*}{$\begin{array}{l}\text { Experience } \\
\text { (Enrolled } \\
\text { FPCU } \\
\text { Student) }\end{array}$} & \multirow{6}{*}{$\begin{array}{l}\text { What were the } \\
\text { experiences of FPCU } \\
\text { graduates in college? }\end{array}$} & \multirow{6}{*}{ Student Support } \\
\hline Technology & & & \\
\hline Majors/Area of Study & & & \\
\hline Support services & & & \\
\hline Professor availability & & & \\
\hline Program/Course Structure & & & \\
\hline Degree completion & \multirow{4}{*}{$\begin{array}{l}\text { Outcomes } \\
\text { (Post- } \\
\text { Graduation } \\
\text { Experience) }\end{array}$} & \multirow{4}{*}{$\begin{array}{c}\text { What were the FPCU } \\
\text { graduates' experiences } \\
\text { upon completing their } \\
\text { degrees? }\end{array}$} & \multirow{3}{*}{$\begin{array}{l}\text { Degrees of } \\
\text { Impact \& } \\
\text { Satisfaction }\end{array}$} \\
\hline School recommendation & & & \\
\hline $\begin{array}{l}\text { Post-Graduation } \\
\text { employment status }\end{array}$ & & & \\
\hline Student-loan debt & & & $\begin{array}{c}\text { Return on } \\
\text { Investment }\end{array}$ \\
\hline
\end{tabular}

According to Smith, Flowers, and Osborn (1997), researchers should begin conducting data analysis by first looking for themes in the first case transcription and make notations. Then researchers should look for connections between emergent themes. The researchers will develop an initial list of themes, then build a cluster of emerging patterns. Data analysis requires that the researcher verify that there is a connection between the themes list and transcription while ensuring that each relationship is viable. Then once the process is completed, the researcher will make a table of the themes using a word processing software. Clusters of themes which are related to the participants' 
concerns should be named. During the process, the researcher should indicate where the item can be found in the transcript, which is known as an identifier. During the process, some themes may be eliminated because they may not be relevant to the emerging patterns or may not be evident in the text. After, the researcher may choose to write up a single case study or repeat the steps as mentioned earlier with subsequent interviews. Per Smith et al. (1997), "Once each transcript has been analyzed by the interpretative process, a final table of superordinate themes is constructed" (p. 74). The researcher may generate a master table of themes.

The final stage of the data analysis process requires the researcher to write up the inferences or summary statement explaining the meanings of the respondents' experiences. Additional analysis is typically after the inferences and summaries are completed. I then analyzed and expanded upon the dominant themes and significant observations of the data.

\section{Trustworthiness}

It is essential to determine if an empirical study is valid and credible, regardless of the approach and scope of the topic. Validity refers to the findings of a study and whether the results are accurate. Lincoln and Guba (1985) laid out procedures to establish trustworthiness in qualitative research and suggested that in order to promote validity in qualitative research, researchers must establish prolonged engagement or spend sufficient time immersed in the data collection and analysis phases to gain an in-depth understanding. Also, to establish internal validity, I conducted member checking and peer debriefing, as well as included an audit trail throughout the data collection, data analysis, and reporting phase of the study. To effectively apply member checks, I verified with the 
research participants if my interpretation of the interviews was accurate via a follow up phone or email communication (Merriam, 2009). Peer debriefing refers to the researcher consulting with a peer, colleague or advisor to examine the data and findings. For the purpose of the study, a committee of university affiliated faculty members was selected to review all phases of this study. I included an audit trail, which is "transparent way to show how data were collected and managed - to account for all data and for all design decisions made in the field so that anyone could trace the logic" (Marshall \& Rossman, 2011, p. 221). The use of audit trails also supports reliability in research studies and is discussed below.

In addition to validity, reliability is critical to the research process and is included to establish trustworthiness. "Reliability refers to the extent to which research findings can be replicated" (Merriam, 2009, p. 27). When dealing with human behavior, including decision-making processes and perspectives, reliability may be challenging. Merriam (2009) stated that as a consequence of varying interpretations of the same data "replication of a qualitative study may not yield the same results, but does not discredit the results of any particular study" (p. 27). Rather, researchers should focus on what Lincoln and Guba (1985) called dependability, which is the integration between data collection, data analysis, and the applied frameworks.

Rodham, Fox, and Doran (2015) emphasized that researchers must establish trustworthiness, as it is essential since the researcher is taking on dual roles as a researcher and insider. Therefore, researchers must explicitly outline their thoughts on each recorded interview. Secondly, researchers should note any potential biases within 
their study to inform the readers. Finally, researchers should share fieldwork notes with colleagues and include reflexive notes online to promote transparency.

\section{Ethical Considerations}

According to Creswell (2007), all data about the research must be kept in confidence and the researcher should use code names or pseudonym labels for participant data. I have maintained high ethical standards throughout the study to maintain the confidentiality and integrity of all participants and data, according to the Florida International University Institutional Review Board guidelines. All recorded audio and video files are stored on my private computer and external hard drive. All paper transcriptions, notes, and codes are kept in a locked storage unit to which only I have access.

\section{Potential Research Bias}

As a former college advisor, I became aware of how students are sometimes misled and uninformed and of how predatory for-profit colleges operate. Many students do not understand the meaning of regional accreditation, articulation agreements, and transferability policies. Students who seek to transfer to a traditional and regionally accredited public or private universities are unable to do so because their credits and degrees are not valid. I am passionate about bringing awareness to students and the higher education field of study. My study aims to understand how students make their decisions concerning what for-profit college to attend. I postulate that students make decisions to enroll at FPCUs due to the colleges' predatory recruiting practices, unawareness of regional accrediting agencies, and lack of self-confidence, the flexibility of course offerings, and other educational options. Therefore, I am aware of potential bias 
and subjectivity towards the student and college consumer perspective. I understand that obtaining a student perspective may contribute to the discourse of for-profit education to spur any interventions. Therefore, I carefully framed interview questions so as not to lead or influence the participant.

\section{Summary}

My objective is to understand why and how students make college selection decisions and under what conditions. Additionally, I plan to investigate choice factors of FPCU graduates within the South Florida region as the backdrop. The research study intends to explore the actual lived and shared experience at the FPCU and the results of graduating from a for-profit college to determine if there are any patterns or implications associated with graduating from a for-profit college within the specified geographic area.

The purpose of this study is to add to the discussion of the for-profit institution sector within higher education. I note here that for-profit institutions are not necessarily poor or have no value in higher education. However, considering the existing options within the South Florida region, I aim to understand the student perspective before, during, and after attending a for-profit institution.

Finally, the results of the study will further determine what, if any, intervention strategies should be implemented to ensure students that are targeted by for-profit institutions are made aware of predatory recruiting practices and potential adverse outcomes. Further research and discussion are necessary to address how and what traditional universities are doing to mitigate this matter. The research participants' perspective, in addition to my own perspective, should include follow-up discussions and debrief to determine if any further insights can supplement this study. 


\section{CHAPTER IV}

\section{FPCU and PARTICIPANT PROFILES}

The purpose of this study is to explore the comprehensive experience of FPCU students who graduated with a post-secondary credential from a for-profit college or university within the South Florida region. This study aims to better understand the FPCU student experience from the decision-making stage throughout graduation and beyond to provide insight on the for-profit college education industry.

I examined the for-profit college graduate experience, from the pre-enrollment phase through graduation and beyond. I wanted to understand how and why individuals decided to pursue a for-profit college degree. I explored their student experience while they were enrolled at a for-profit college and university (FPCU) and find out what their post-graduation outcomes were. As an underlying objective of this study, I wanted to understand how participants felt about their academic journeys and how their journeys related to their current professional status. Ultimately, did their credential help them achieve their desired goal. Using their own narratives, I aimed to have participants tell their stories. In order to explore and report their journeys, it is critical to understand the background of the participants and provide context of their academic experience during their educational path and thereafter.

For additional context of the for-profit student experience, I first present and highlight the present standing of each for-profit college represented in this study. Due to the changing status of for-profit colleges and universities, it is critical to include their status. FPCU standing can vary from normal operations to transfer of ownership and closures. Multiple lawsuit settlements, government sanctions, and accreditation 
violations have plagued the for-profit industry within the last ten years and therefore, I include if such outcomes have impacted the represented for-profit institutions within this study.

This chapter also includes participant profiles that specify demographic information and highlight the associated themes that emerged throughout the data analysis process, after the for-profit institution overview. I present each participant profile in the order the interviews were conducted. The profile of the research participants addresses their bio-demographic information including age, gender, and ethnicity. Additionally, each participant profile includes his/her academic history and credentials. A significant component of this study addresses employment and career aspirations. As such, participant profiles also include a snapshot of their employment status from preenrollment through graduation to their current employment status and future career goals. I conclude this chapter with an overview of the participants and briefly introduce the emergent themes from the data analysis process.

\section{Represented FPCU Profiles}

This section addresses the eight represented for-profit institutions within this study. I begin with the largest for-profit university in the United States and the most represented within this study, the University of Phoenix. Then I continue down to the institutions with the least participant representation. Each institutional profile includes a brief historic summary, enrollment and/or graduation data, the status of the FPCU and relevant information pertaining to grievances and lawsuits. I present the institutional profile consisting of enrollment data, academic programs, and the institutional status. I include the for-profit institutional status because the for-profit market experiences change 
from closures to renaming and transfer of ownership. There are also considerable issues surrounding the sector, including the loss of federal funding, class action lawsuits, and the shift from a for-profit model to a non-profit model. Therefore, I provide an outline of the represented for-profit institution (including owner/operator) status to supplement the participant profiles.

\section{University of Phoenix}

The University of Phoenix excels in enrollment, serving as the largest for-profit operator in the United States. The University of Phoenix offers an array of degrees from the associate level up to the doctoral level in education, business, information technology, psychology, criminal justice, nursing, and healthcare management among other academic disciplines and offers coursework in fully online and in-person formats. The institution also offers certificate programs, continuing teacher education courses, and professional development in business-related disciplines.

The University of Phoenix is the largest represented for-profit college in this study, with four participants earning a total of six degrees. It is the flagship institution of the Apollo Education Group, a subsidiary of Apollo Global Management, which was founded by John Sperling in 1973. John Sperling was a tenured history professor at San Jose State University and left the institution to launch a program for working professionals (Bartlett, 2009). The university is the largest operating for-profit institution in the United States. In 2010, the university enrolled approximately 470,000 students. However, enrollments have steadily declined and in 2016 the University of Phoenix enrolled 130,000 students (McKenzie, 2018). Since 2010, enrollment at the institution has fallen by $76 \%$ (Marcus, 2019). According to the University of Phoenix website, $66 \%$ 
of the student population are women, with males representing $34 \%$. Further, $40 \%$ of the student population identify as Caucasian. African-Americans represent $28.1 \%$ of total student enrollment and Hispanics total $14.5 \%$. The institution offers both graduate and undergraduate degrees; the most popular degree programs are in business.

In 2015, the Higher Learning Commission, a regional accrediting body, removed the institution's probationary status (Thomason, 2015). Also in 2015, the institution was banned by the Department of Defense from recruiting students on military bases and barred from using military tuition benefits; however, the decision was reversed in 2016 (Altman, 2016; Douglas-Gabriel, 2015). The institution has one of the lowest graduation rates at $14.9 \%$ for the University of Phoenix-Florida. The graduation rate is based on the six-year timeframe from enrollment to degree completion of individuals pursuing a bachelor's degree (Data Set from the Chronicle, 2019). In 2019, a private equity investment group purchased the Apollo Education Group (Marcus, 2019). As recently as 2019, the university settled with the Federal Trade Commission and agreed to pay a $\$ 141$ million to cancel student loan debt to individuals who attended the institution from October 2012 through 2016 (Chappell, 2019). The claim alleged that the university employed fraudulent recruiting practices and overstated job prospects with well-known companies including Microsoft and AT\&T (Chappell, 2019).

\section{DeVry University}

DeVry University represented three earned degrees within the business-related disciplines among three participants in this study. The university offers associate's, bachelor's, and master's degrees in addition to undergraduate and graduate certificates. Courses are delivered through online formats and in-person. In 1931 Herman DeVry 
founded the institution. According to the university's website, Herman DeVry created a career-focused and technology driven institution to assist working professionals to positively impact the labor market. In 1973 two former DeVry instructors founded the Keller Graduate School of Management. The Higher Learning Commission regionally accredits the university. In 2017, Cogswell Education LLC purchased the university from Adtalem Global Education, formerly known as DeVry Education Group (Smith, 2017). In 2017, DeVry University's enrollment was approximately 17,000 students. The total student enrollment breakdown is similar to the University of Phoenix. White students represent about $50 \%$ of the total student enrollment. Black or African-American students represent $24 \%$ and Hispanic students are $16 \%$ of the student population (Data Set from Data USA, 2019). The most common awarded degrees are within the business and computer systems fields. The university has three Florida campuses and several campuses nationwide. In 2016, DeVry University agreed to settle claims the institution had misrepresented employment prospects to students - the settlement totaled to $\$ 100$ million (Marcus, 2019).

\section{Strayer University}

Strayer University touts itself as a fully accredited institution designed for working professionals. The university is represented in this study with two participants earning a Master of Public Administration degree. The institution offers associate's, bachelor's, and master's degrees, as well as certificate programs. In 2018, Strayer Education and Capella Education Company (Capella University) merged and now enroll about 80,000 students combined (Whitford, 2018) with approximately 50,000 of those students enrolled at Strayer. Prior to the merge, female students accounted for more than 
$66 \%$ of the student body and over $90 \%$ self-identified with at least one racial minority.

Strategic Education Inc. owns and operates Strayer University. The Middle States

Commission on Higher Education, a regional accreditation body, accredits Strayer

University. It was founded as Strayer's Business College in 1892 and changed to its

current name in 1998. The university delivers courses online and maintains 76 campuses

nationwide with eight campuses in Florida. According to Data USA, the student loan

default rate for Strayer University in 2016 was 19.2\% (Data Set from Data USA, 2019).

Argosy University, The Art Institutes and Brown Mackie College

Education Management Corporation (EDMC) was previously the second-largest for-profit operator nationwide. Prior to filing for bankruptcy, EDMC owned Argosy University, The Art Institutes chains, and Brown Mackie College. Between these three institutions, there was one participant with a degree from The Art Institute, one participant with a degree from Argosy University, and two candidates with earned associate degrees from Brown Mackie College.

In 2016, due to decreased enrollment and increased regulation, EDMC closed Brown Mackie Colleges nationwide (Smith, 2016). In 2017, EDMC sold The Art Institute chain and Argosy University to non-profit Dream Center Holdings; however, the Dream Center has since ceased operations due to the loss of federal aid by the Trump administration and as a result, Argosy University closed campuses nationwide in March 2019 (Kreighbaum, 2019). The Art Institute of Miami is now operating as the Miami International University of Art \& Design and is owned by a non-profit body, Education Principle Foundation. 
EDMC experienced several lawsuits and in 2015 settled what was reported as the "largest false claims settlement with a for-profit educational institute in history" for $\$ 95.5$ million (Jackson, 2015). The allegations of the lawsuit centered on college recruiter compensation. At the time of the lawsuit settlement, EDMC operated seven campuses in Florida. Because of the settlement, EDMC agreed to forgive student loans for about 80,000 students totaling \$102.8 million dollars (Saul, 2015).

\section{Everest College (University)}

Corinthian Colleges, Inc. was the former operating owner for Everest College. In 2015, after increased scrutiny, several class action lawsuits and federal fines, Corinthian Colleges, Inc. filed for bankruptcy and ceased operations. Corinthian Colleges was fined \$29.7 million dollars for falsifying job placement rates (Stratford, 2015). As a result, Everest was sold to non-profit Zenith Education. Other Corinthian Colleges campuses were sold to Educational Credit Management Corporation. Recently, efforts to establish student loan forgiveness programs and settlements have stalled under the Department of Education. While some former students have obtained clear guidelines, others are still awaiting court decisions (Kreighbaum, 2019; McKoy, 2018). Everest University represented one study participant who attended the institution while it was still a forprofit college.

\section{American Intercontinental University (AIU)}

American Intercontinental University represented two degrees by one candidate within this study. The institution offers online programs and has two campuses in Atlanta, Georgia and Houston, Texas. Associate's, bachelor's, and master's degrees in addition to certificate programs are offered in field such as business administration, 
technology, criminal justice, fashion design, and information technology. The institution enrolls about 10,000 students, with African-Americans representing $49 \%$ of the student population. White students account for $40 \%$ and Hispanic students represent three percent of the total student population (Data Set from Data USA, 2019). General business, information technology, and criminal justice represent the popular degree fields, with business representing about $60 \%$ of awarded degrees (Data Set from Data USA, 2019).

Career Education Corporation owns and operates American Intercontinental University in addition to other for-profits such as Sanford-Brown and Le Cordon Bleu North America. Career Education Corporation has closed campuses nationwide due to lawsuits and federal findings over the past decade (Stewart, 2019). The AIU South Florida campus was closed in 2015. As of January 2019, it was reported that Career Education Corporation reached a settlement to forgive student loans totaling $\$ 493$ million, affecting close to 180,000 former students (Stewart, 2019). The lawsuit centered on fraudulent recruiting practices and inflated job placement rates. In March 2019, it was reported that Career Education Corporation plans to purchase Trident University International and merge it with AIU (Lederman, 2019). However, it was reported that Career Education Corporation is under investigation by 17 states. Job placement rates and recruitment concerns are under question (Marcus, 2019).

\section{Summary of FPCU Profiles}

The represented for-profit institutions provide context and a peek into the research participants' experience. Large national institutional chains such as the University of Phoenix and DeVry University compared to that of smaller schools such as AIU demonstrate minimal difference with respect to the racial enrollment breakdown and 
degree specializations (i.e. business). Further, I indicated relevant lawsuit settlements and accreditation fines associated with the represented institutions. It is evident that the forprofit college sector is marred with hefty fines and allegations of fraud. Despite these well-documented cases, these institutions persist. To complement the for-profit institutional profiles, the following section addresses the study participant profiles.

\section{Participant Profiles}

I conducted this study to explore the culminating FPCU student experience. I limited this study to South Florida due to the array of for-profit colleges within this geographic region. In Miami alone, there are more operating for-profit colleges with a brick and mortar campus than public and private non-profit colleges. Therefore, I figured that the South Florida region, from West Palm Beach to Miami, would provide a diverse participant pool.

In total, 12 participants were recruited and selected for this study. There were 11 female participants and one male participant. The research on the for-profit college sector affirms that the overwhelming majority of FPCU students are women (Chung, 2012). Ten out of the 12 participants were primarily located in Miami, Florida during their academic tenure at an FPCU. The majority of the research participants, seven out of the 12 participants, identify as African - American and five participants identify as White-Hispanic. In addition, seven participants are within the 30-40 age range, while four participants are within the 40-50 age range and one participant is within the 50-60 age range. The represented sample participants support the research on for-profit students, which specifies that FPCU students are mostly minority women over the age of 25 
(Boykin, 2017). A summary of the participant demographic data including the earned FPCU degree information is presented Table 1.

\section{Kate}

Kate is a White-Hispanic female in her mid-thirties. She attended Brown-Mackie College on a "brick and mortar" campus in Miami, Florida from 2006-2009 and earned an Associate of Arts degree in Business Administration from Brown Mackie College. From 2012-2014, she attended Argosy University in a fully online program and graduated with a Bachelor of Science in Business Administration. While pursuing both programs, Kate was a full-time employee of The Art Institute of Miami (Ai), starting as administrative assistant and was then promoted to a student employment advisor after completing her associate's degree. Since she was a full-time employee at the Art Institute, her tuition expenses were covered through tuition remission benefits.

Kate indicated that proximity and convenience, in addition to financial assistance, were deciding factors, which led her to enroll and pursue a degree at Brown Mackie College. She stated that she did not have to drive to campus after work; she would simply go to another floor within the same building she worked to attend classes. She selected business as her major because she would "have more opportunities" with business and that "I was already in education, so I can go into any other industry or field within the business." Kate further explained:

I knew that I needed to complete my college degree in order to move forward in my professional career. I obviously I wanted to get a degree to move on in my career, in my professional life. I wanted to make sure I got the right education and the tools I needed in order to move on. 
During the pre-enrollment and decision-making phase, Kate determined that earning a college degree would be a stepping-stone for professional advancement. It seems that she wanted to obtain knowledge and transferable skills so that she would be able to pursue additional-- and perhaps what would be to her--better career options. Further, she had already decided that her current position at the time was a benefit; she would be able to work and study with minimal costs. The decision to enroll was essentially a win-win.

Prior to starting her bachelor's program at Argosy University, Kate was promoted to career services advisor in 2012 and she remained in that position until 2018. As of 2019, Kate serves as a mid-management administrator for a career services unit for graduate students, within a private non-profit university, a position she considers to be a promotion. She attributes her current career status "not only my education that I have a degree but also my experience within career services. I think those two factors contribute to where I am now."

When describing her experience as an FPCU student, Kate explained:

I had a good experience. I mean, they're (for-profits) smaller schools. They're not huge like the non-profit, like traditional schools. So, I think they give a little bit more attention to their students versus, you're on your own in the other university. They're (traditional colleges), like, okay, here are your classes, go ahead and register yourself. So here, it was more personal attention.

Kate's experience as a for-profit college student and employee provides insight from a unique perspective that celebrates the strengths of the FPCU industry. Kate was 
aware of some of the reputational pitfalls large universities encompass and articulated that her student experience included student consideration. Kate's positive summarized experience as an FPCU student and her achieved career objectives demonstrate a journey that is rarely told within the for-profit college literature. She was able to obtain two degrees without incurring debt and accomplished professional advancement.

\section{Sara}

Sara is a White-Hispanic female in her early thirties. She graduated from DeVry University in 2014 with a Bachelor of Business Administration degree with a concentration in health services administration. Her bachelor's program was conducted fully online. Prior to enrolling at DeVry University, Sara was a nursing major at a local community college in Miami and previously completed coursework at a four-year private non-profit institution, where she is currently employed as a mid-management administrator. She chose to pursue business as a major after learning that the higher education industry shared business practices, as she no longer had interest in becoming a nurse.

Sara is married with children and maintained full-time employment during her program at DeVry University. Her spouse is an employee of DeVry University and first introduced DeVry University to her as an option to continue her education. Sara has been employed at a private four-year university in Miami, Florida for over 10 years and had the option to pursue a degree using tuition remission benefits from the college. However, she chose to attend DeVry also utilizing tuition remission through her spouse. The fully online program provided flexibility since she worked full-time and has children.

Although she could have continued her studies at the private non-profit university where 
she worked, she did not feel comfortable doing so. Sara explained what made her choose DeVry University over the private university where she is employed:

I think it was more for me the flexibility only because of work, not having to drive and rush and get out of here, ask for time off, if I could leave early. It just wasn't what I was looking for. I did take two classes at here at the university, and I can say it was not a great experience. And, so I was, like, "I am not going to deal with this either." I had different, I guess, experiences, and I noticed that my experience where I was here. I was not happy with the professors. It felt very impersonal. It felt competitive. It felt as if everybody was coming in to see just who's better than who? When I attended the courses here, it didn't feel like a home environment. It didn't feel like the professor was really looking out for you. So the difference, even doing it online with DeVry, the professors would reach out to us literally every day in email communication. "How are you guys doing?" I ended up getting pregnant around 2015, and my professors were accommodating to me. "If you need to take some time off for the doctor, let me know." The constant communication with that is what also led me to just continue to go with them, because it was a really great experience. Sara had contrasting experiences at DeVry University and the private non-profit university. From Sara's interview, it was evident that she did not have a pleasant student experience while taking courses at the private institution. She felt that there was a lack of care and consideration for students from her instructors. The competitive environment at the private institution was something Sara deemed unwelcoming. She spoke about her 
student experience at the private university with sadness. However, when speaking about her experience at DeVry University, her eyes would light up and her voice would inflect to represent excitement and genuine happiness. In addition, the fact that Sara's program was fully online provided a convenience factor. She would not have to request time off to attend courses during business hours and would not have the added pressure to make it to class on time. Sara also indicated that the time to completion was much shorter at DeVry than at the private non-profit university. She explained:

I knew it was going to take a long time for me to graduate (at the private institution), because I've seen it with other friends that have done it here, and they graduated in, like, eight years. So, it was kind of life consuming too because I had other plans that I wanted to do, and I didn't want to continue just to be in school every day! I had other plans that I wanted to reach as far as career-wise.

Three years after completing her degree from DeVry, Sara was promoted to her current position. She indicated that she pursued the degree for her own "personal fulfillment" and that obtaining the degree has made her a more confident person. However, she feels that her salary does not match her job duties and looks to continue to grow professionally and financially.

\section{Tiffany}

Tiffany is an African-American female in her late thirties. She is a single mother of five children, from age one to 14. She earned two degrees from the University of Phoenix, an Associate of Arts in Education in 2017 and a Bachelor of Science in Business with a Human Resource Management Certificate in 2018. She is currently pursuing a Master of Arts in Education/Adult Education and Training with an anticipated 
completion date in 2020 . The programs Tiffany has completed at the University of Phoenix are fully online programs, including the graduate degree program in which she is currently enrolled. Tiffany is currently employed as an entry-level administrator at a private four-year college in Miami, Florida and plans to pursue a doctoral degree in adult education upon completing her master's degree.

Although Tiffany had attended trade schools previously, she did not consider attending college after high school. She stated that her motto was "college is not for me." However, she was "not happy" with where she was and wanted to make a change: Every job that I wanted, you had to have more than what I had. I had a high school diploma. But I had to have more. I really was afraid to step out in the college arena, because when I first graduated from high school, I always said college was not for me. That was my main [pause]. I lived by that.

During the interview, Tiffany expressed feeling stuck and wanting to be able to do more for herself and her children. Prior to learning about the University of Phoenix, Tiffany explained that she wanted more in life and wanted to pursue what she considered to be better career opportunities. She said that college just wasn't for her and she lived by that ideal for so long.

However, when she sought other jobs, she was told that she needed credentials greater than a high school diploma. She realized that she wanted to become a teacher but needed to obtain a degree to be eligible for teaching positions. She mentioned that her fear of college life while also being a single mother kept her from pursuing a college degree. 
Tiffany was referred to the University of Phoenix by one of her children's teachers, who also graduated from the University of Phoenix, after having a conversation about career opportunities. Tiffany was previously employed as an after-care teacher on a part-time basis in Miami when she first started at the University of Phoenix. She made the decision to pursue a college degree because she "wanted more." As a single mother, she sought an online program that was "convenient" for her.

Because I needed to be with my children, I didn't want to go through the process of you know, getting a baby sitter, and getting off work trying to rush. It was just too much, and I felt doing it at home online, I could set my own schedule. It would be less stressful and I could work. I would know my time frame and I could meet my deadlines.

Tiffany's desire to pursue a degree that did not conflict with her work schedule and parental obligations were a primary factor for selecting to attend the University of Phoenix, fully online. As a working, single mother of five, Tiffany was aware that the time she would need to dedicate to her studies, children, and work was limited. Therefore, University of Phoenix's online degrees were attractive in that she would be able to manage her time effectively and work at her own pace to minimize stress and additional pressure.

Tiffany began her tenure at a private non-profit university in Miami in 2016 as an entry-level administrator, a role that she currently holds at the time of this writing. Similarly, to Sara, Tiffany had the option to pursue a degree at the private non-profit institution she works for with tuition assistance. However, she ultimately elected to continue her studies online at the University of Phoenix 
because of their "customer service" and like Sara, did not find the environment at the private institution welcoming.

I think because throughout my time at the private non-profit university, I was able to have a different outlook on a different college, as far as fouryear education, private school goes. And I've talked to advisors. I've talked to students. I've talked to faculty, not about college, but I've interacted. I don't see what I saw at University of Phoenix. I don't see a lot of happy students. I don't see a lot of de-stressed students. I don't see a lot of happy faculty. I don't see a lot of support.

What Tiffany has witnessed as a staff member at a private four-year university has further evidenced that she made the right decision to attend the University of Phoenix. Her experience and observations have shaped her perspective of the traditional private institution. She would much rather attend a for-profit university where she receives the support and attention that she believes she would not receive at the traditional university.

The support that she received from the enrollment process through graduation was evident in her narrative. She exclaimed that she received constant support from her professors and encouragement from her advisors. Tiffany described personal challenges she faced during her studies as an example of the support and care from the University of Phoenix. She was offered the option for a leave of absence due to the death of her mother and a miscarriage:

It was hard throughout some years of doing so, because I've dealt with the loss of a baby, which threw me into a depression. The loss of my mom, 
you know, which threw me. A lot of things came up, and my advisor reached out. "Hey, I haven't seen you post. What's going on?" And I told her, "It's a rough time for me right now." And she was like, "You have alternatives." They gave me the alternatives. You can take a break and start back. "You tell me how long you need. Actually, you have 180 days that you can take a break." And she was like, "There's no way you should feel stressed, or if you're overwhelmed, or if you're going through something. There's no way you shouldn't take a break if you have 180 days." It was such a simple process. They email you the form. You sign it electronically. Send it back. You get an email. Set a day. The process is so easy. Everything is right there. If you don't know something, they walk you through the process. For lack of a better word, maybe holding your hand just to give you that assurance that you're not in this alone. We're here to help. So that made a big difference for me. I mean, because sometimes you need a break. And I didn't want to take a break, because it throws you longer to finish, but in some cases you need it. But I'm very happy with University of Phoenix. I mean, I had the chance to go to university for free, but I chose to rack up loans all because of their customer service.

Although Tiffany encountered personal life challenges while enrolled at the University of Phoenix, she was able to secure support and encouragement from her advisors. She appreciated the simplicity and availability of options to pause her studies 
without penalty. Because of the support she received, Tiffany believes that attending the University of Phoenix was the "best decision" she's ever made.

Tiffany decided to take out student loans rather than attend a private non-profit university with tuition assistance. She summarized her experience as positive and proudly recommends the University of Phoenix. She plans to further her education at the University of Phoenix with a doctoral degree in adult education and desires to become a university professor.

\section{Linda}

Linda is an African-American female in her early 40's; she is unmarried with no children. She earned a Master of Business Administration (MBA) with a healthcare certificate from the University of Phoenix in 2009. After high school, she attended a private four-year college in Miami but then transferred to a large public state institution in South Florida where she obtained a Bachelor of Health Sciences degree. She originally wanted to go to medical school and to become a doctor; however, she struggled academically. She is currently employed as an entry-level administrator at a large public institution in South Florida, where she also earned her bachelor's degree. She has aspirations to become an entrepreneur for healthcare products.

Linda stated that she always wanted to obtain an MBA. She considered the University of Phoenix after learning that she could not pursue an MBA at a well-known private non-profit institution nor the state institution where she works due to her academic performance during her undergraduate studies. As a result, she was conditionally admitted to the University of Phoenix and was informed that she would need to meet certain GPA requirements to be fully admitted. Linda attended the 
University of Phoenix both in-person and online. She stated that she was excited after learning that she was fully admitted. When asked to describe her eagerness and initial feelings of being admitted and going to classes, Linda expressed:

Yes. I was excited, and I did everything that I could to get through the courses. Once I went to the courses, I sat at the front. I was attentive. I did all the assignments and I passed with A's, so yeah, I was excited to start the program. And also, when I got through with the three courses (as part of the admissions condition) and they told me that I was fully admitted, I was also excited for that as well.

Although Linda had been given admission conditions to attend the University of Phoenix, she seemed to be grateful for the opportunity. She had already been denied admission from two other institutions. She believed that the MBA degree would prepare her to establish a business. Since Linda had previously attended two four-year institutions prior to attending the University of Phoenix, I asked her to compare her experience between the two previous institutions and the University of Phoenix:

The setting was a small group thing, about 10 to 15 students in each class. Compared to when I went to [private university], science courses were probably 100 students. Also, at the [public institution] there were about 100 students per class. I guess it all depending [sic] on what class you took. But I know the sciences, they [sic] were more students compared to the courses at University of Phoenix. At the University of Phoenix, there were very intimate classes, so the teacher had more one-on-one rapport with the students, and we got to know more about the professor and have a rapport with them on a day-to-day basis. 
Linda expressed that the small classes benefited her and she was able to excel in this course format. She indicated that the intimate course setting resulted in her achieving A's, as compared to her undergraduate experience where she did not do well in large courses, which resulted in her poor academic average. Within the large courses, she was unable to develop a rapport with her instructors. Linda summarized her experience at the University of Phoenix as follows:

It was a good experience, and I would recommend the college. I don't know how it is now, but I would recommend University of Phoenix for people who are working full time and they don't have time to go to classes in person. They reach out to you and make sure that you stay connected with your group, as well as being on top of your assignments and stuff. So, I would recommend University of Phoenix.

Linda expressed her student experience at the University of Phoenix as positive. The format of online and in-person seemed to have benefited her academically. She appreciated the small courses and university engagement. Linda believed that she would "automatically get a job" after graduating with an MBA. Although she did pursue career opportunities, she has not yet experienced career advancement upon graduating. She stated about her MBA, “It hasn't had an impact yet because I need to get something that is more rewarding than what I have right now, and I'm still looking."

\section{Nicole}

Nicole is a White-Hispanic female in her late thirties. She holds a Bachelor of Science in Health Management from the University of Phoenix. Nicole agreed to participate in the study when she viewed my social media posts requesting for study 
participants. She completed the fully online bachelor's degree in 2014. She is married with two children. Nicole attended a local community college after graduating with a high school diploma in 2000; she was initially a nursing major. Due to personal life events, she dropped out of the community college and eventually transferred to the University of Phoenix in 2011. She is currently employed as administrative director for a behavioral healthcare facility in Miami, Florida.

Nicole was employed as a receptionist in a dental office and recognized that she enjoys the healthcare field from an administrative/management perspective as opposed to clinical practice. She stated that she realized that she could no longer grow in the healthcare field without a degree. Her cousin, who recently graduated with a bachelor's degree at that time, referred Nicole to the University of Phoenix. She wanted to pursue an online program because of the flexibility it offered and so she could attend to her children. She described her thought process and enrollment process as follows: At the time I already had my two girls. I didn't want it to take away time from them, right? I'm like, "Okay, I want to go to school but what's the least sacrifice?" "What can I do to least sacrifice their time?" "What can I do to make sure I do what I have to do but not take time away from them?" Because my husband also had a very demanding job and he couldn't be as flexible, so I still needed to be available. My cousin went to the University of Phoenix and she highly recommended it. She had a good experience and I'm like, okay. I called them. She gave me their number. They were really quick in responding to me. I had a good advisor. By that I mean she was a nice and very helpful counselor. And literally, within a 
week, I was registered to school. I sat down and I spoke to my husband because what ended up happening was that I couldn't work. I wanted to go to school full-time. My husband was doing okay at the time, where I could kind of minimize my hours and so do more school than work. And then I had to have a talk with my boss. And what ended up happening was that instead of getting less hours at my job, I ended up leaving my job and getting a part-time somewhere else, where I can work from home, as well as go to school from home. And so, it all kind of happened really quickly but I think because I was so determined, I got the bug and I didn't want the bug to go away. I signed up and, yeah, within a week I was registered for school.

While enrolled at the University of Phoenix, Nicole worked for an online company remotely and worked part-time as a seasonal employee for the county elections department. She was able to manage her household, work remotely from home and complete her coursework in the evening. She appreciated the instructor and advisor support throughout her online program and was able to manage her academics, home-life and work obligations.

Nicole described her post-graduation experience:

And so, after I graduated, I was still working for the elections. But I knew I wanted to work. Okay, now I have to start looking for work. Now I have to present my resume. The thing that I was confident about is that even though I didn't have any management experience, I had eight years already in the medical field. So wherever I was going to work, depending on how it would happen, it 
would be entry level. I knew that my resume contained that I had just graduated with my degree in management. I don't have management experience, but I have health management. I have eight years' experience in at least the medical field. That kind of started me applying. I applied for everything. I applied for Baptist. I applied for AvMed. I applied for Humana. I applied for every kind of medical job and I was on every job postings.

Nicole was determined to obtain a position in the field in which she studied and had experience. She realized that she needed to get her foot in the door and sought positions that matched up with her education and skills. About one-year post-graduation, Nicole received a job offer from her previous employer from the oral surgeon's office. She was offered an office manager position and worked in that capacity for almost two years. She now serves as the administrative director for an autism therapy center. She attributes her work experience and degree from the University of Phoenix to where she is now:

There are plenty of people who have a degree and unfortunately haven't been able to show too much for it. For me, the decision that I made five years ago to go to school, right now, is showing. That's what's kind of flourishing. My degree and what I learned.

Nicole is aware that often times, a higher education credential does not automatically equate to success or a better paying job. She considers herself fortunate in that her degree is aligned with her career. As a result, Nicole is successfully able to meet her parental and professional responsibilities. She seemed to have had a positive experience at the University of Phoenix and is 
benefiting from the opportunities her degree and experience has afforded her. To Nicole, the sacrifice was worth it.

\section{Michael}

Michael is an African-American male in his late thirties. He holds a bachelor's degree and a law degree (Juris Doctorate) from a Historically Black College and University in Florida. Diane, a study participant, referred Michael for this study. Michael is a licensed state attorney and earned a Master of Public Administration degree from Strayer University in 2012. He maintained full-time employment as a state attorney during the fully online program at Strayer University. He is married and a father of three children. Michael is also an adjunct professor at a local for-profit institution in South Florida.

He was referred to Strayer University by a close friend, who also graduated from the same institution. He wanted to do an online program that would not interfere with his law career. Michael sought avenues to teach at the collegiate level, but not teach in law school. He learned that in order to teach government or civics courses, his academic credentials would need to be supplemented with a master's degree:

I wanted to get into teaching as well. As a lawyer, really, you would teach legal classes to law school students. I didn't want to do that. But you could use your law degree to a certain extent to teach in the undergraduate level. But what would also help you substantially was a Master's. I didn't know this until I started wanting to teach on a collegiate level. So, with that information, I said, 'All right, what the hell? I'll just go ahead and get a Master's. I mean, that way I can kind of open up different doors for me.' 
Evidently, Michael was interested in teaching civics and public administration courses rather than law specific courses. He wanted to reach and connect with undergraduate students. It seemed that Michael was interested in giving back and teaching at a for-profit institution would be that avenue to do so. He strongly identifies with his professional identity as a practicing defense attorney and considers teaching at a for-profit institution as service.

When asked about comparing his undergraduate and law school experience with Strayer University, he responded by indicating that he was able to control his academic pace:

Control, more than anything. Strayer gave me the control, whereas law school and undergrad was more structured in classroom time. But as far as how I picked my classes in undergrad and law school, I picked those based on when I wanted to be available. But I went to school when I needed to. So for example, this week coming up, I had a trial, and I knew I needed to prepare for trial. The beauty about Strayer was that you received an assignment on Monday. You had to submit it by Sunday. So you got it that Monday, it was submitted by that Sunday at midnight. So for me, the control aspect was beautiful, because I was able to -- If I'm going to get it on that Monday, but I'm going to be in trial, I would wait until that weekend, and then I would shut down for the weekend and get it all done and knock it out. Or if I knew that the latter part of my week was going to be heavy, when I got it on Monday, I tried to knock it out Monday, Tuesday, so that way I was done with whatever my weekly requirement was. Not to say the semester 
project or anything like that, but whatever my weekly requirement was, I was able to take care of it that way.

Having the control to work at his own pace was a differentiating factor for Michael. As someone who had the traditional college experience, an established career, and achieved personal/societal norms, a Master's in Public Administration appears to be a completed line item on a to-do list. Michael sought to pursue another graduate degree without compromising his career and personal duties. Ultimately, pursuing a master's degree at Strayer University provided the teaching opportunities he sought after. He was able to secure steady courses, teaching at a local for-profit college teaching American National Government. When I asked about how he was able to secure his teaching position, Michael expressed:

The department head that brought me in, he kind of brought me in doing a different route. He used my legal degree as a means to get me in to teach the legal courses. Then I finished school. I had my degree. Everything was good. That department head left. So for like a year and a half, I didn't teach. Another gentleman came on campus, and he was looking for someone to teach American National Government. I think through a friend of mine, he ended up approaching me. Because I had that degree, they got me back through the door and I taught American National Government on a consistent basis at, I want to say, two different campuses for three or four different semesters. Then the department head for the legal department saw me, and I was able to get my foot back in the door with the legal department. I've been doing it ever since. 
Michael's experience as an HBCU graduate, law school graduate, and for-profit college graduate provides a unique perspective to the literature. He regarded his experience at Strayer University as transactional. However, he had this to say about his culminating academic experience:

I think that Strayer's system of education, if it could be incorporated in a traditional college setting, that traditional colleges would be able to market to a different kind of student. But I don't know what that would do to colleges and universities like Strayer. Would it put them out of business or not? I think the reader has to understand this. I live by this and I die by this. When I went to HBCU, I had a professor named Dr. Brown. Dr. Brown told me, he said that, "People mistake college for high school. High school, the teacher's responsibility is to teach you. College, it is your responsibility to learn. I'm simply a facilitator of information and knowledge. It's up to you to get it." I've always carried that with me. So I would say, and any reader that's reading this needs to understand that you could pick any school in the world. But if you don't apply yourself and do anything, it's never going to work for you.

Indeed, Michael used his academic credentials to establish himself as practicing attorney and adjunct instructor. During Michael's interview, he appeared to be passionate about education as a means of personal and professional growth. He is socially conscious and regards himself as an advocate and success story to young African-Americans. 


\section{Diane}

Diane is an African-American female in her mid-to-late forties. Diane and I are colleagues at the same university and when I was discussing my dissertation topic, she informed me that she earned a degree from a for-profit college and would like to participate in the study. Diane holds a Bachelor of Science in Elementary Education from a Historically Black College and University in North Carolina. She is single with no children. She attended Strayer University's fully online Master in Public Administration program, graduating in 2011. She is currently employed as a director-level administrator at a four-year private non-profit university in Miami, Florida. When asked about her undergraduate experience, Diane expressed that it was non-traditional. She explained:

I wouldn't say my education has ever been traditional. I was untraditional, a nontraditional student, even in undergrad. I went in my first semester and into my second semester, and then I withdrew (from courses). Then I started working and then I went back to school years after that, because I enjoyed my job. I worked on campus and literally started my career when I was 20. And the reason I finished my bachelor's degree was because my mentor was like, "I'll never hire you as a permanent employee." But she was benefiting because I knew how to do this stuff better than her regular employees did. I'd much rather go to work than go to class. And it just took me a lot longer to finish my bachelor's. But that experience, I mean that was in the classroom, which was on the campus. That was me being school age, college age, to me being an employee of the university. Even as a temp and people knowing me based on my employment and then 
being older than most students because now I'm nontraditional in these classrooms and still working at the university. So it, by no means, was my undergrad traditional either.

Diane described herself as a non-traditional student while completing her bachelor's degree in North Carolina. She was an employee of an HBCU in North Carolina and stated that she was older than her colleagues with whom she attended courses. Diane's mentor guided and motivated her to finish college. She had always worked and when she made the decision to pursue graduate studies, she recognized that she would maintain full-time employment while doing so. Diane decided to pursue a master's degree because she knew her mentor had a master's degree and she wanted to follow her mentor's example. She stated:

For me I was like, "I'm going to finish. I'm going to finish with all A's." And I just wanted to have my degree. So that was the biggest thing for me. I just, I wanted a master's. My mentor, she had a master's degree. I kind of followed in her footsteps in what I wanted to do. I didn't know how it would benefit me in my career, but I knew it was something that she had. So that was one of the motivating factors for me doing it. For Diane, her mentor played a significant role in her academic accomplishments. Her mentor motivated her to obtain and complete her bachelor's degree and served as a catalyst for Diane to pursue and obtain a master's degree. Diane was referred to Strayer University by a close family friend. She elected to pursue a graduate degree in public administration because at the time, she believed it was aligned with her career field in higher education. 
However, as she continued her studies at Strayer University, she realized that the degree was not closely related. Despite learning that public administration was not relevant to her career in higher education and recognizing her lack of interest in the public administration field, Diane stated that she remained determined to complete the program.

During her interview, Diane indicated that she does not believe that her master's degree affected her career. She seemed indifferent to the fact that her degree could have played a role in her professional advancement. She expressed that she was promoted three years after obtaining her degree, but the promotion was in title only and not in pay:

For me, I had done everything in the area that I work in. I had held all the positions except for director. So my hope was that it would help in me becoming a director, or greater, at some point to have a master's degree. It came to fruition, but I don't know if my master's, I can't say that it helped. Maybe it did. My situation is a little different because when I became a director, it was under an administrator that was very racist. And so financially it did not matter. I got the director title, but I didn't get the money that comes with it. So I think that was more him than it was my credentials to show that I should have been [a director]. So it's hard to call whether or not I benefited. I know some directors in my profession that don't have master's degrees. So, I can only assume it helps. Although Diane does not attribute her professional advancement to her degree, she does recognize the value. She was offered an adjunct teaching position upon graduating from Strayer University, although the opportunity fell 
through. She stated that her degree "served its purpose" and she was emphatic that she would not pursue any more degrees. When asked if she had any plans to teach at the collegiate level, Diane indicated:

In order for me to teach what I would want to teach, I'd have to go back to school and I refuse to go back to school. Like, God is literally going to have to come to me in a burning bush and say, 'Thou needs to go back to school' before I do it.

As emphatic as Diane was about the idea of not continuing her education, she clearly has a passion for helping others. For Diane, she does not enjoy the research aspect of college. She considered pursuing a graduate certificate in higher education but elected not to because she did not want to "write another paper." However, when I asked what she would teach, Diane specifically outlined her teaching interests:

It would have to be something that would allow me to work with students on a real-time type of system. I think our kids need to understand the basics that school doesn't teach them, which is how to write resumes, what your emails should be like, proper etiquette in meetings and in lunches and if you're meeting with clients. Like, social media is so crazy now. Now you have to be almost on some stealth type situation online because it follows; it never goes away. Just giving them real life experiences with their finances. I can tell you what I did and why you shouldn't do that. I can tell you where I am financially and why that's not necessarily where you want to be financially. I have had tests, so I have testimonies. I that I think in a classroom setting that would help and give people real world 
experience. And I looked into how I could teach almost like one-on-one. I forgot what they tell me the degree had to be in, something that would allow for that type of teaching. And if 'thou' is said and I had to go back and do it, it would be in that area, where I could work with new students. It appears that Diane is interested in working with students in a life-skills or life coach capacity. She wants others to learn from her past missteps and experiences. Although her academic route was non-traditional, Diane seems to have benefited both professionally and personally. With guidance and motivation from her mentor, Diane secured academic credentials and maintains a senior level position at a private four-year institution.

It wasn't a bad experience at all. It was school. My best friend did it in two years. It wasn't anything to him. He went in and did it. I mean, it was literally a piece of cake. But for me it was, I'm over it. Like, I wish it was done. Okay, so now it's taking me forever to finish. My two-year [degree] took four years just because I didn't want to do it anymore. I hated the time it was taking up. But I don't have anything negative to say about Strayer. It served as a purpose.

Noticeably Diane's collegiate experience varied between an HBCU and Strayer University. She stated that the reason it took her four years to complete her graduate degree was because she realized that she was not interested in public administration and realized that she did not enjoy the research component of college. The main motivating factor for Diane to obtain a master's degree was her mentor. Although she had a positive 
experience, Diane wishes that she had pursued a degree that would allow her to reach young people focusing on life skills.

\section{Helen}

Helen is a White-Hispanic female in her late 50's. Her interview was conducted via Skype. She has a very thick Spanish accent and so at times it was challenging to understand her. However, Helen was very animated and happy to participate in this study. A colleague who was a former admissions director at the Art Institute of Miami referred Helen for this study. They have managed to keep in touch throughout the years.

Helen is widowed with one adult child. In 2016, she earned a Bachelor of Arts in Interior Design from the Art Institute in Miami (Ai). She was considered an international student and studied at the Art Institute under a student visa for four years. She attended the Art Institute's downtown Miami campus in person.

In 2012, while Helen came to Miami to visit her son, after her husband passed away. At this time, Helen was a Venezuelan citizen and Panamanian resident. She was visiting the United States on a tourist visa. After her husband passed away, she sought avenues to remain close to her son in the United States. Helen's attorney informed her that she would need to either marry a U.S. citizen or enroll in a college to obtain a valid visa to remain in the country. Ten months later, Helen was enrolled at the Art Institute in Miami. As an international student, she was ineligible for financial aid and paid for the program out of pocket, totaling over $\$ 100,000$. Helen explained that she had the means to pay her tuition:

Oh, listen it was easy because, as I told you, I have the money, so they said first of all, $\$ 8,000$ and I don't know how much, and I just wrote a 
check. So every three months, I guess I had to pay the tuition. But I paid the whole thing. I don't know, it took me a little bit, every three months, something like that.

Helen came from a family with means and she recognized that she was in a position of privilege. She stated that many students with whom she attended the Art Institute for interior design ended up as salespeople at furniture stores. Helen seemed to understand that the cost to attend the Art Institute was expensive but she had the funds to do so while she would be able to remain close to her son.

That's really sad because it takes a lot of time and a lot of the money. It's four years of your life, a lot of money, and it's not a cheap career. $\$ 100,000$ more or less, and it will end up warranting a furniture salesperson? That's so frustrating. Interior design had always been a passion and hobby for Helen. In her home country, Venezuela, she had built and designed homes, although she was not officially credentialed in interior design. She stated, "I just Googled interior design. I was pretty clear about what I wanted to do. So, Google automatically sent me to the Art Institute, which is the closest one to my house." Helen expressed:

I used to do interior design but I didn't have the right knowledge, and in Venezuela you don't need that. In Venezuela, I didn't work as an architect, but I could build a house. I can do that over there. I knew how to do it. I always wanted to do it better and I did it for all my apartments and my houses and my family. I was helping everyone. I never made one dime out 
of it, but I loved it. So people always called me to do so, like for 20 years.

So, I went to university.

The primary reason Helen decided to pursue a degree in interior design was so that she could remain in the United States. However, she selected a field that she had experience in and held genuine interest. Helen was aware that she would not be able to obtain a work visa in the United States upon completing her degree at the Art Institute. She did look forward to working in Panama and stated:

I was expecting to work here in Panama. But, the boom in Panama is over.

So the people that are doing interior design here are very related to the architect firms. And then if there's no possibility to get [pause] or you have some really good connections. And so I didn't get that experience over there (in the United States). I didn't know when I came back here, it was almost five years that I was away. So, I came here like a year and eight months ago and I didn't know anyone.

Although she was unable to secure employment in Panama as an interior designer, she is grateful to have had the opportunity to live in the United States and attend a university studying interior design. She mentioned that the process afforded her five years of residing in the United States close to her son, while attending school. Helen summarized her FPCU experience as fun.

It was cool. It was fun. The good thing is that I was really close to school and I used to drive or bike, or Metro-mover. That area is so cool. So you know, it was really fun. It was really fun. I mean I don't behave as my age, okay? These kids, we used to party together like it was normal. And we 
worked together for some projects as well. We helped each other, just like teammates; it didn't make any difference at all.

Helen, clearly a non-traditional student, took advantage of what could have been a more unfortunate circumstance. The unexpected loss of her spouse coupled with limited opportunities to be close to her son in Miami was a situation that Helen did not anticipate. Luckily for her, she sought an alternative option that did not include marrying a U.S. citizen to remain in the country. During her interview, Helen indicated that she had a fun experience while a student at the Art Institute. She was able to travel, maintain a close relationship with her son and enjoy the Miami life. Helen's experience is unique in that she benefited from her experience from a personal perspective. Even though she did not experience career growth or professional advancement in the interior design field, she is content with her life and enjoys being a grandmother. At the time of this writing, she currently resides in Panama City, Panama and works remotely with her son's real estate company on a part-time basis.

Amy

Amy is an African-American female in her early 40's; she is single with no children. A former colleague referred Amy for this study. Her interview was conducted via teleconference. She earned two degrees from the University of Phoenix, an Associate of Arts in Healthcare Administration in 2013 and a Bachelor of Science in Psychology in 2016. Amy is currently pursuing a graduate degree in public administration from the University of Phoenix and is expected to graduate by December 2019. All of the programs that Amy completed at the University of Phoenix are online, including the 
program she is currently pursuing. She transferred from the state university where she is employed to the University of Phoenix:

A family member was attending the university at the time, and I was struggling trying to finish my degree at the state university. So she put me onto her academic advisor at the University of Phoenix. I guess working full time and trying to work eight hours full day and then, after a long day, sitting in a classroom wasn't an option anymore. So, I decided [on] the transition from the state university to the fully online world.

Amy expressed that being able to work full-time and complete an online program on her own time was beneficial. As a result, she was better able to manage her course load. Although she would have preferred to complete her studies at the institution where she works, she mentioned that it was not feasible. She stated, "I guess working full time and trying to work eight hours full day and then, after a long day, sitting in a classroom wasn't an option anymore."

Amy expressed that she wanted to progress in her career and was told that in order to be considered for career advancement opportunities, she would need to have earned academic credentials. After graduating with her associate degree, she was provided a monetary incentive from her employer. Upon completing her bachelor's degree in psychology, Amy was provided another monetary incentive and was also promoted. Amy described her experience after earning her bachelor's degree: At first I thought that it was over. I didn't want to attend any more school, but then an opportunity came available and I applied. And my application did not get considered because I was told that the master's degree was 
needed even though I had the years of experience. So, they no longer look at years of experience here.

Amy communicated her disappointment in that her application would not be considered. However, after learning this, she decided to continue her education and pursue a master's degree at the University of Phoenix. She is currently employed at a state university in South Florida as a mid-management administrator and upon graduation will seek higher positions in her department. When I asked Amy to summarize her experience at the University of Phoenix, she expressed:

The experience with the working full time and having the chance to go home and take a breather for a couple of hours and not having to jump right into school right after you get off from work was great. You got time to space out. They gave you a deadline, so it's not like you had a weekly deadline. You don't have an everyday deadline; you have like a week deadline. So right now currently in my graduate program, the week starts on a Tuesday, but the deadline to submit any assignments may not be until the following Monday. So you have time throughout the week to post your participation and respond to your students. It wasn't like a rush to try to get everything done at once.

Being able to work at her own pace while working full-time was a significant component for Amy. She would have preferred to complete her studies at the institution where she worked, but she was unable to excel academically. The University of Phoenix's course format was suitable for Amy and she 
continues to further her education so she can be eligible for additional career opportunities. When I asked Amy what her personal thoughts were about the University of Phoenix, she said, "It's a great school. I would recommend it to anybody that's willing. If they can't fit into the traditional classroom setting, I would recommend it. Totally recommend it." Amy appears to have had a positive experience at the University of Phoenix. She is proud to have graduated from the university and wants readers of this research to know:

I would have loved to complete my degree for the institution that I currently work for. It just was not something that I could have done back then with the demands of the job, the demands of the current daily responsibilities. It's just as this institution evolves and brings in more and more students, it's harder to focus on school when you have so much on your plate to do throughout the day.

Overall, Amy is optimistic about her career path and exhibited pride over her accomplishments. Despite the challenges she faced, Amy considered the University of Phoenix as a viable option to reach her goals. She mentioned that her father is also proud of her and that has given her a sense of joy. Amy has goals of moving up within her department and she has already experienced a promotion after obtaining her bachelor's

degree. She plans to continue to seek professional development opportunities and maintains a positive outlook.

\section{Victoria}

Victoria is an Afro-Hispanic female in her early 40's; she is married to a now retired military former enlisted military service member and has two children. A former 
colleague referred Victoria to participate in this study. Her interview was conducted via teleconference. Victoria graduated from Columbia College of Missouri, a small liberal arts college, with a Bachelor of Science in Criminal Justice Administration. She graduated from DeVry University's, Keller School of Management, fully online Master in Accounting and Financial Management program in 2010. Victoria described her process when she considered going back to school:

I had a best friend that I grew up with that actually was already attending and was already in the same program that I decided to go into. Before I decided to go into that, I was working part-time in loss prevention. I had a manager who has this degree in accounting and finance, but he was a former military police officer, then a state police officer, and then he did this, that job as managing the loss prevention program on a military installation. It just grabbed my attention what he was doing. Aside from managing the employees who are doing the security for the store, he was also managing the profits and loss of the store as well. Just how he went about doing it and all the auditing part of it that really caught my attention. I no longer wanted to continue with my criminal justice background into the workforce. After I had children, that all changed. I wanted to find a way to merge my criminal justice background with something different. This was perfect because my friend was doing a program, the MAFM, that was a Master's in Accounting and Finance Management with an emphasis of certified fraud examination. I thought it was a nice way to merge the two degrees and not lose all those four years that I had done previously. 
Then she told me there were courses online, and I was a new mother with a husband. He wasn't deployed, but he wasn't going to be home for six, seven months, so that was proving difficult to have to leave the house to attend college and get my master's. Then I decided to do the online program, and it actually was a great fit for me. I liked the short courses. They were only eight to 10 -week long courses. It allowed me the flexibility that I needed as an at-home mom.

Victoria stated that she wanted to merge her background in criminal justice with the accounting and finance field. She specifically wanted to focus on loss prevention and fraud. She learned about DeVry University's graduate program through a close friend of hers, who was also enrolled in the same program. Victoria wanted to pursue an online degree because at the time, her husband was a military officer and she was a stay-at-home mother. Therefore, Victoria sought online programs so she could attend to her parental obligations without having to leave her house. Throughout her studies at DeVry University, Victoria was a stay at home mother. She appreciated the support she received from her professors, as they were responsive and interactive.

Victoria's higher education experience from both her undergraduate and graduate universities can be described as non-traditional. When I asked Victoria to compare the two experiences, she expressed:

Oh, wow. It was a little bit different because when I went to Columbia College, it wasn't in Missouri, in Columbia, Missouri. It was a satellite campus in Alabama on a military installation. It's very different. I've never experienced life at a community college other than that. It was always at a satellite school, if that 
makes sense. Yeah. I never had that experience. It's a little different for me because I got married at a young age. I was married at 20 . We got married really young. I was in college working full-time when I went to Columbia College. Victoria continued to describe her enrollment process and life circumstance when she considered attending DeVry University:

When I was at DeVry, I was an at-home mom. I babysat. That's what I did on the side to make money, so it wasn't like I had a full-time job. It's two very different experiences. When I was working full-time and going to school, it was very small classrooms because, again, it was on a military installation. It was limited to how many people can even attend, period. It wasn't an open installation where anyone can come in. There, you just couldn't come into the place. The classroom sizes were small. The course content was very in-depth, even though the semesters were also short. My experience of them, the community college for both the schools, the semesters were short, and I really liked that. I don't like sitting in a classroom for four months learning one subject. I think that's a waste of time. Some content may take longer, but I think most is not. I think by the time you're done with the class and you go to your next one is that you almost forgot it already. To me, give me what I need to know now and get it done. Condense it, because at the end of the day most of what you're going to be doing is on the job training. Then utilize the tools and the information that you learned in your college and master's program. You can have all the degrees in the world, but if you don't have the experience, it's hard. That was interesting. Mind you, I wasn't working in my field either when I was studying criminal justice. 
Victoria's higher education experience seems to have been shaped by her affiliation with the military. Although she is not an enlisted officer, Victoria sees and labels herself as a military spouse. As a result, her academic choices were influenced by military benefits and what comes with being a military spouse. For example, she obtained an undergraduate degree from a liberal arts college that operates on military bases. She was motivated to continue her studies utilizing her background in criminal justice because a colleague, who was also in the military, was able to demonstrate a potential career pathway that Victoria identified with and thus pursued.

After graduating from DeVry University, Victoria began her job search. She described her post-graduation experience:

Afterwards (employment) was proven to be extremely difficult to do. At the time we were just coming out of a recession, and a lot of military members had just been forced to get out of the service. The military was downsizing. Because of that, they give veterans preference for federal work, which made it extremely difficult for me to even get a foot in the door. I found it so hard. I used their resume service that the school had. They had job fairs that they offered, and they also had resume builders and things like that. I was still an at-home mom. I was still concerned about being full-time in the workforce with having small children. I was still not $100 \%$ onboard on going out and being a full-time worker and having a family. I did a little bit of applications that I put out there, but I don't think I was serious about it until about 2014, which is what, three years later. 
Victoria did secure employment a few years after graduation. She is now working at a credit union bank and stated that she would not have the job she now has without having the degree. She also expressed that she would not have the salary she has without the degree. She and her family have relocated three times since graduating. She stated that she has been able to transfer branches during each relocation while maintaining her salary. She now resides in Kissimmee, Florida with her family.

\section{Rachel}

Rachel is an African-American female in her late thirties. She is a single mother of two children. Rachel responded to my social media post on LinkedIn requesting participants for this study. Her interview was conducted via teleconference. Rachel earned two degrees from American Intercontinental University (AIU), the first being an Associate of Arts in Business Administration and the second degree she earned was a Bachelor of Science in Business Administration with a concentration in Human Resource Management. The associate degree program at AIU was conducted in a traditional campus setting, while the bachelor's degree program was considered hybrid, courses were conducted both in person and online. Rachel also earned a Master of Business Administration (MBA) from Everest University in 2017. The program at Everest University was also hybrid. Rachel described her enrollment process:

They actually didn't come to me. I went to them. I was in the process of a 12-year relationship breakup. The relationship ended on a Sunday, and on that Monday morning I decided that I want to better myself and go to school. So I went online, just Googled the nearest school and I looked at AIU was one of the first schools that popped up, so I just went there and 
signed up and I took the AA, BA program where I was connected from the associate degree program into the bachelor's program, so they're integrated. I was actually excited. Excited to obtain a degree, better myself, and give my children an example actually.

Rachel was motivated to pursue a higher education by a significant life event. Her relationship had ended and the breakup caused her to take action to "better herself." To Rachel, a college degree would serve as a catalyst for her to improve herself. She was excited to have what could be described as a fresh start and become an example for her children. When I asked Rachel if she considered other colleges or universities she answered:

I did look at a few other schools, but AIU stuck out to me. The location was not too far from where I lived, one. A few my colleagues told me it was a phenomenal school to go to. That was one of the main reasons I went as well.

Rachel's primary motivating factor to pursue a college education was sparked by her breakup. However, AIU's location along with the support of her colleagues helped Rachel to solidify her decision. During her time at AIU, she found the associate degree program to be easy. However, she struggled during her bachelor's program because of the online format and she was juggling obligations of being a single working mother: With online classes, you're really pretty much teaching yourself. I don't feel that you're getting enough support with online classes. I think that between working full-time and writing 10-page papers, 20-page papers, having children, I found it hard and very challenging for me. I persevered 
through it, but it was hard. But because I had the drive and I knew I wanted to be successful is the reason why I was able to even get through it.

Rachel pursued her master's degree because she thought it would help her become more "marketable." She graduated with her MBA in 2017 and expressed her frustrations about the outcome. She indicated she has continued to "revamp" her resume and applies to higher paying positions within the higher education industry and corporate setting: I thought that when I graduated I would be walking into a corporate job. I'd be able to be more marketable. I thought that it'd be much easier for me to find something versus me remaining in the same position. My pay has not increased within the last, I want to say almost a decade. I'm pretty much been at the same pay rate.

Although Rachel values her academic credentials from AIU and Everest University, she feels that debt she incurred was not worth it. She believes that FPCU's should do more to assist students with employment and career opportunities. She summarized her FPCU experience by stating that the expense was far too high and that FPCU's are only looking out for themselves and not the students that attend them. Rachel is employed as a mid-level administrator at a local for-profit college in South Florida.

\section{Kim}

Kim is an African-American female in the 30-35 year age range. She is married with two children. A mutual colleague referred Kim to participate in this study. Her interview was conducted via teleconference. Kim is a graduate from Brown Mackie College (BMC) and DeVry University. She earned her Associate of Science degree in 
Accounting from BMC in 2010. She graduated from DeVry University with a Bachelor of Accounting in 2013. Kim attended Brown Mackie College and DeVry University in a traditional "brick and mortar" campus in Miami, Florida. Kim also attended Miami-Dade College and transferred earned credits to DeVry University. Kim described her enrollment process:

When I graduated from high school, I was going to just go to Miami-Dade College. But when I was enrolling, they told me that I had to take so many pre-requisites. I think about two years worth of pre-requisites before starting the associate's degree. I did not want to do that. I'd be waste time and money doing that. My aunt heard about what happened and she told me about Brown-Mackie College. So I went and they accepted me right away; I think the same day. I was just so happy that I could do the program without have to do a bunch of pre-requisite courses.

After graduating from high school, Kim considered and attempted to enroll at a local community college. Going to college was the next logical step after high school for Kim. However, after she learned that she would need to complete approximately two years of pre-requisite courses prior to beginning her associate level degree, it did not seem worth it to her. She did not want to "waste time and money doing that" so she decided not to enroll. Her aunt referred her to Brown Mackie College and she learned that she could immediately start an associate program. Time seemed to be a critical component for Kim. She did not understand why she was required to complete prerequisite coursework. During this period, Kim thought that she would be wasting money for courses that would not apply for her degree if she elected to attend Miami-Dade 
College. She did not see the benefit and thus determined that Brown-Mackie College would suit her needs with respect to earning a degree.

Upon enrolling at Brown Mackie College, Kim was interested in the business field. In her first accounting course, she became enthralled with accounting and had an engaging professor encourage her to pursue accounting as a major. During her time at Brown Mackie College, Kim described her experience as "easy, it reminded me of high school. The classes were very small and intimate. It was very hands-on as well.”

After graduating from Brown Mackie College, Kim found it difficult to obtain employment in the accounting field, "I couldn't find a job to save my life." She would obtain interviews and recalled that interviewers would ask her questions about Brown Mackie College and did not seem to know of the college. She stated that she found herself explaining that it was a small private school and even questioned if Brown Mackie was accredited. In her frustration and disappointment, she eventually assumed a role as an income tax preparer, worked in retail, and "did odd jobs" after earning her associate's degree.

About one year after graduating from Brown Mackie College, Kim received a call from DeVry University indicating that they were reaching out to her because she was interested in completing a bachelor's program. Kim did not recall submitting an interest form and had not previously heard of DeVry University. Although wary of the unsolicited call, Kim decided that she should continue her studies and considered attending the local community college for a bachelor's in accounting. However, she was informed that her credits from Brown Mackie College would not transfer to the community college and thus she would need to start over. As a result, she contacted the 
enrollment advisor at DeVry University and was assured that her credits would transfer. Kim enrolled in the bachelor's program at DeVry University's campus in Miami.

Kim described her experience at DeVry University as pleasant. She was engaged in her courses with her professors and received student support from her advisors and administrative deans. While making academic progress at DeVry, Kim reached her federal financial aid limit. In order to continue at DeVry, she had to pay her tuition out of pocket. She was advised to take courses at the local community college, since the tuition was less expensive and then transfer credits back to DeVry University, which she did. Kim is currently employed in a private charter company as an accountant. Kim summarized her post-graduation experience:

Finally, after I got my degree from DeVry, I was able to get an entry level job with a CPA firm as an accountant. I now work for a private charter company with an internal accounting department. But it has not been easy. I should have just gotten my bachelor's degree, that way I would have avoided loans, which I don't know how I am going to pay it off. I owe more than $\$ 40,000$ and the money I am making is not enough to cover my student loans. My student loans are way too much for this industry. Kim's higher education experience was interesting in that there were both difficulties and triumphs. She may regret not obtaining her degree from MiamiDade College as she experienced hardships after completing her degree from Brown-Mackie College and needed to take classes at Miami-Dade College anyway to complete her bachelor's degree. She ended up maxing out her loans by attending DeVry University. However, Kim was able to overcome the academic 
and financial challenges she faced as a student to persist and graduate. Ultimately, Kim secured employment in the accounting field and is working to pay off her student loan debt.

The participant profiles provide context and a background of how each participant viewed their academic pathways. In each narrative, the study participants outlined the pre-enrollment perspective and addressed their FPCU student experience utilizing positive or negative connotations. Their background in terms of family obligations and career aspirations was also present and all participants addressed their financial commitments associated with pursuing a degree.

\section{Summary}

The goal of this study is to explore the FPCU graduate experience with South Florida as the backdrop. The majority of the participants are female and located in Miami, Florida. Research confirms that most FPCU students are women of color and this research sample aligns with the for-profit college literature. Further, this study includes a snapshot of some well-known for-profit institutions directly.

This chapter addressed the demographic and biographical summary of each participant to provide context for their culminating experience as an FPCU graduate as it relates to the academic journey and post-graduation outcomes. It is important to consider the participant background, earned academic credentials and pre, during, and postgraduation experiences as these color and shape how each participant views and describes his/her journey. Additionally, I highlighted the specific and individual life factors of the participants that are relevant to the student experience. 
A profile of the represented for-profit institutions was included to provide additional context to support the participant summaries. Both the participant and FPCU profiles contribute to the overall discourse surrounding the for-profit college industry and the students who earn degrees from said institutions. Therefore, it is important to consider the FPCU context as it is a component of the research findings.

There are evident patterns and shared experiences from each participant. The findings suggest that there are pre-enrollment components that relate to career aspirations, which are components in the decision to pursue a higher education. Evidently, a trusted associate or family member referred the participants to the FPCU. The research participants determined that flexibility was an important component of the decision. Although each participant recalled their student experience, student support in the form of professor assistance and availability was a common theme presented and repeatedly indicated in their narrative. Further, the respondents specifically indicated their post-graduation experiences. Some participants experienced hardships while others experienced promotions and obtained their desired career outcome. The participants acknowledged the financial component of their experience. They alluded to the cost/benefit analysis and some participants seem to have benefited from tuition remission advantages while others are undergoing challenges related to student loan repayment. The following chapter will present the emergent themes in detail and include supporting detail. 


\section{CHAPTER V}

\section{THEMATIC ANALYSIS}

Grubb and Lazerson's (2004) education gospel concept postulates that educational credentials are the pathway to success; this framework guides this research study. The education gospel framework specifies that higher order skills and advanced knowledge are required because of shifting labor market demands. In order to keep up with changing labor needs, individuals require skills beyond a high school education (Grubb \& Lazerson, 2004). As a current graduate student, educator, researcher, and professional within the traditional higher education arena, I value education and believe that academic credentials may result in additional economic and professional opportunities for some. Further, as I progress in my own career and manage others', I recognize the need for higher order skills and knowledge and believe that academic credentials provide the avenue for obtaining advanced skills and knowledge. Therefore, I too subscribe to the principles of the education gospel and hypothesize that the majority of the study participants also subscribe to this conceptual theory.

Based on the education gospel, the assumption is that students who attend college also value education as an avenue for personal and professional (economic) success. Throughout this chapter, the findings of this study support the notion that education, in the form of academic credentials, serves as a pathway for personal and professional success. This chapter presents the emergent themes obtained from 12 in-depth interviews of students who graduated from a for-profit college and university within the South Florida region. Following the participant and FPCU profiles presented in Chapter Four, I include a presentation of the significant patterns developed from the data analysis 
process. I report the findings from the pre-FPCU enrollment stage to the student experience perspective and a description of the outcomes as told by participants from a career and financial viewpoint after graduation. Finally, a summary is provided to address the culminating presentation of the findings.

The major findings as obtained through one on one interviews are Access and Choice, Student Support, Degrees of Impact and Satisfaction, and Return on Investment. During the data analysis process, I recognized that the three first themes stemmed from the coding process were aligned with this study's research questions: Why did FPCU graduates choose to attend a for-profit college? What were the experiences of FPCU graduates in college? And what were the FPCU graduates' experiences upon completing their degrees? The Return on Investment theme is an important consideration of the overall FPCU student experience and was substantially present within the participant narratives which I felt needed to be included in this study.

Access and Choice relates to why participants decided to pursue a post-secondary credential and how they ultimately chose to attend an FPCU. Access refers to the specified motivating factors for pursuing a post-secondary credential. Participants sought access to additional career opportunities and reported that obtaining a degree would provide the access to those career goals. Choice refers to how participants selected the FPCU from which they eventually graduated. The majority of the study participants were referred by a friend, family member, or trusted associate and selected the FPCU primarily based on that referral. Additionally, participants specified the need for "flexibility" and "convenience" as decision factors for choosing the for-profit they attended. Student Support describes the participant experience as an FPCU student and the perceived 
support they received during their academic journey at an FPCU. Participants reported that they received professor assistance and were either supported or encouraged by their academic advisor throughout their academic progress. Degrees of Impact and Satisfaction outline the results and outcomes of earning a degree mainly from a career and financial perspective of the FPCU graduate. Participants described the outcome of earning a degree from an FPCU from a career and economic viewpoint. The study participants indicated if and how their FPCU degree affected their career advancement opportunities.

Additionally, this theme incorporates an element of degree satisfaction from a postgraduation perspective and includes a summary of the respondents' culminating academic experience. The fourth theme, Return on Investment, relates to the participants' overall perspectives of their earned degree, including degree satisfaction, and the personal and financial investment standpoint. The study participants indicated the perceived degree value or worth in terms of overall satisfaction and the incurred financial expenses associated with obtaining the degree. Further, this theme addresses the cost and student loan factor by each participant. The following is a presentation of each theme with corresponding detail. Refer to Table 4 for a summary of the Thematic Descriptions. Table 4

Thematic Descriptions

\begin{tabular}{|c|c|}
\hline Theme & Descriptions \\
\hline Access \& Choice & $\begin{array}{l}\text { 1. Access refers to the specified motivating factors for pursuing a post- } \\
\text { secondary credential. Participants sought access to additional career } \\
\text { opportunities and reported that obtaining a degree would provide the } \\
\text { access to those career goals. Choice refers to how participants selected } \\
\text { the FPCU from which they eventually graduated. A majority of the } \\
\text { participants were referred by a friend, family member or trusted } \\
\text { associate and selected the FPCU primarily based on that referral. } \\
\text { Additionally, participants specified the need for "flexibility" and } \\
\text { "convenience" as decision factors. }\end{array}$ \\
\hline
\end{tabular}




\begin{tabular}{ll}
\hline Student Support & $\begin{array}{l}\text { 2. Student Support refers to the support participants received during } \\
\text { their tenure enrolled at an FPCU. Participants reported that they } \\
\text { received professor assistance and were either "supported" or } \\
\text { "encouraged" by their academic advisor. }\end{array}$ \\
$\begin{array}{l}\text { Degrees of Impact \& } \\
\text { Satisfaction }\end{array}$ & $\begin{array}{l}\text { 3. Participants described the outcome of earning a degree from an } \\
\text { FPCU from a career viewpoint. The study participants indicated if and } \\
\text { how their FPCU degree affected their career advancement. The } \\
\text { satisfaction component refers to the extent to which the participants } \\
\text { were satisfied with their academic credential. Additionally, the } \\
\text { participants specify their culminating experience. }\end{array}$ \\
& $\begin{array}{l}\text { 4. The study participants indicated the perceived degree value or worth } \\
\text { in terms of overall satisfaction and the incurred financial expenses } \\
\text { associated with obtaining the degree. Further, each participant } \\
\text { addresses the cost and student loan factor. }\end{array}$ \\
Investment &
\end{tabular}

\section{Access and Choice}

As mentioned in Chapter Two, Access and Choice within a higher education backdrop refers to student access (from a financial perspective) to institutions of higher education and student choice primarily focuses on student factors leading to why they chose to attend a particular college (Perna, 2006). In other words, college access refers to financial limitations and policies that provide or bar access to students seeking entry into an institution of higher education. Additionally, the choice framework is more commonly viewed from a human capital perspective. The Access and Choice concept is not commonly applied to for-profit college students. However, I borrowed these terms to describe the emergent theme addressing why students decided to pursue a post-secondary credential and how they learned about the FPCU and why they ultimately decided to enroll at a for-profit college.

During the in-depth interviews, participants expressed that access to career advancement opportunities was the primary driving force in the decision-making process. Most of the study participants determined that obtaining a post-secondary degree would 
be the first step in establishing occupational progress in their respective field. Eleven out of 12 study participants stated that they chose to pursue a post-secondary education as a pathway for additional career opportunities and/or professional advancement. Although 11 study participants were working either full-time or part-time during the enrollment process and throughout their degree program, participants indicated that access to career opportunities and advancement was a factor for pursuing a post-secondary degree. In this context, access is described as a route for career opportunities. Sara stated that: Initially, I was actually going to go back to Miami-Dade (community college), because I was already there. I was, like, "Let me just think about it." I talked to my husband, but he put me in contact with an advisor from DeVry, and that's when I met with her in person. I went to the office. And it just felt so real, it felt so present, it felt so that she really cared about me. She cared about the fact that I did want to have my education. That's always been one of my goals, as an accomplishment, that I wanted to do, because I didn't get a chance to before, and I was already older, and I was thinking I really want this as part of my list of accomplishments as my career grows, because I know opportunities arise when you have a degree. So, that drove me to that.

As Sara described her thought process above, she stated that by earning a degree it would provide access to career advancement opportunities. Even individuals with established careers, such as Michael who is a practicing attorney, mentioned that obtaining a master's degree would "open up different doors." In this context, participants expressed the desire to pursue or have access to their 
desired outcome of the possibility of more employment prospects. This possibility is a strong motivating factor resulting in participants to take action and decide to pursue a higher education or advanced degree in some cases.

Nicole and Rachel decided that going to school would provide an avenue to "better myself." Nicole stated, "I went back to school in the first place to better myself, for a better future, for a better job, for a career. That was my goal. That was my mindset." Rachel also shared the same sentiment and stated that she made a decision to "better myself and go to school." Both Nicole and Rachel found themselves unable to progress in their respective positions in health management and education. They indicated that in order to become "better" they must acquire post-secondary credentials. Nicole and Rachel perceived that a degree would provide access to career and employment gains, and as a result of the employment gains, they would be able to enhance or improve their circumstances and lifestyles.

Other participants stated that earning a degree was expected in their employment industry, particularly in higher education. Diane expressed that having a master's degree was an expectation as a senior level university administrator:

I just knew that for me personally, I needed a master's degree. I don't need a Ph.D. to do what I do in my profession. There is no college degree for my profession. So, for me it was just having the credentials, because when you're in a collegiate setting, they expect you to have particular credentials and you really can't move without them. And I wanted to be 
able to move. It wasn't going to be because she doesn't have an advanced degree. I have it. So now, what's next?

Diane revealed that without having a graduate degree, although there is no specific degree for her field, she did not want to miss out on an opportunity because of the lack of credentials. Her years of experience alone would not be sufficient if she wanted to move up in her career. Additionally, Amy, who also works in the higher education space, shared a similar expectation to Diane:

Working where I'm working now, I've been told for years that in order for me to go higher I needed to get my degree. And so that's what pushed me to pursue the degrees. So I've just been trying to push it to try to get it to get a better position.

Amy, who earned an associate's and bachelor's degree and is currently enrolled in a graduate degree program at the University of Phoenix, was informed that she needed academic credentials to be eligible for a promotion. In this context, Amy and Diane concluded that access to higher-paying positions, management level roles, or positions with complex and advanced responsibilities requires a college degree and in some cases, graduate degrees. This degree expectation within the higher education industry is warranted, especially in Amy's and Diane's positions, as they service students in the academic records and financial aid regulation units respectively.

Evidently employment outcomes and the presumption that individuals should have a degree are driving indicators for pursuing a college degree. However, one research participant indicated reasons other than career advancement opportunities. Helen stated that in order for her to stay in the United States and be close to her son in Miami, Florida, 
she would need to either re-marry or attend college as an international student. Helen explained:

I lost my husband in 2012 and I went because of my son. He was living already in Miami and he's married and I wanted to be close to him. So, I had two choices, either I get married or I went to school. So of course, I decided to attend school. I went to a lawyer, and I knew it, but I just made sure I had all the options. So, he told me what I knew, either you get married to some American guy, like uh-uh (negative) I am not getting married; I'm not doing that.

Helen elected to pursue a bachelor's degree because she had always been interested in interior design and had informal experience building and designing homes in her home country of Venezuela. The four-year bachelor's degree program at the Art Institute of Miami allowed her to remain in the country under a student visa for the duration of her program. Helen, an outlier in this study, does provide insight into how she leveraged her interests with her personal circumstance, along with her financial means to pursue a degree. Helen's primary motivating driver was to stay in the US and she did not consider future employment prospects.

The research participants expressed that either they were stagnant in their employment status or that they wanted "more" or "better" opportunities. In order to achieve and obtain their desired outcome, participants decided to pursue and acquire a degree. For some participants, they decided to pursue a degree because it was an expectation within their occupational setting, in particular within the higher education administration industry, and an advanced degree was required to be promoted. However, 
it was clear that the participants believed a degree would provide that access and based their decision on that belief.

Regarding FPCU choice, participants expressed how they came to learn about the for-profit college. This process seemed to have stemmed after participants decided to pursue a degree and took into consideration their options. Nine out of the 12 of the research participants specified that were referred to the for-profit college they attended and graduated from by a family member, close friend, or trusted colleague who had also graduated from a for-profit school. Tiffany recounted how she came to learn about the University of Phoenix and how she made the decision:

I shared with my child's teacher like, 'I'm not happy.' She was like, 'Well, what do you want to do?' I was like, I don't know. I need some more money. And she's like, 'Have you ever thought about going to school?' And I'm like, 'No way.' She was like, 'Just call and see, find out what it's about. You said you never heard of it.' I didn't. She was like, 'You don't know what you like until you try it.' And I said, 'Well, that's true.' So that's why I made the call, and I've been going since that day I called. Six years ago. So I received information about University of Phoenix from one of my children's teachers that had previously [gone] there, graduated, and she had a little experience with them. So she gave me the number. I reached out to the school just to get some information. I wasn't sure, but I just wanted some information to see how their program ran and different things about how it would actually be, how long it would be. What is the process of everything? And so, I got in contact with an 
advisor. I reached out, and I mean, the same day they had me fully informed. They wanted to know my interests, so I gave them my interests. And within, I would say, two hours, they had an email to me with all of the information there, so I can thumb through everything. They had the website so I can go on and review everything to see what I wanted to do. A trusted confidant who also graduated from the University of Phoenix referred Tiffany. After Tiffany inquired about the institution and met with admissions counselors, she was promptly enrolled. Tiffany confided in her child's teacher and clearly developed a sense of trust with this individual. The trust factor and referral Tiffany received, was a significant component in her enrollment decision.

Victoria shared a similar experience. A close friend referred Victoria to DeVry University and when I asked her if she considered other colleges, she responded:

Yes, I think I considered the University of Phoenix, Strayer, and Capella. They were all options, but I think I decided to go with this one simply because my friend was going there. I had the comfort of having her walk me through it if I needed anything because accounting was completely new to me. She already had 10 years of experience in accounting. My first semester, it was hard. I didn't know debits from credits. I didn’t know what that was. She had to help me with some of that, but after my first semester it was smooth sailing. 
The comfort and trust Victoria felt is akin to Tiffany's experience, in that they both knew someone who attended the institutions. Victoria's decision to attend DeVry University was essentially a win-win. She would be able to have support from her friend and the university provided the flexibility she needed as a stay-at-home mom. In both Tiffany and Victoria's experience, both decisions were made with the minimal risk in knowing that they were referred, which may have reduced the anxiety factor and that the programs were convenient to them so as not to interfere with their parental duties. Additionally, Nicole, like Tiffany and Victoria, is a parent and shared a comparable experience:

I knew that from my cousin's experience, she kind of told me, that it was flexible. We did have a long conversation. How her day looked. How her assignments were. I did know from what she told me was that it was very loaded with paperwork. Because it was an online program, it was a lot of papers. She did tell me like okay, it's a lot because everything's online and you have to be very self-motivated.

A close cousin referred Nicole to the University of Phoenix and she obtained insider information with how her experience was going to be at the University of Phoenix. With this information, Nicole was prepared to embark on her studies, knowing that someone close to her shared the same experience. Therefore, Nicole, like Tiffany and Victoria, may have had a sense of security in their decision. The participants encompassed trust in their referral and the referral's institutional experience, which led the participants to be confident in their school selection or choice. 
In Amy's case, she previously attended a traditional non-profit institution and transferred to a for-profit college after being referred. I asked Amy how she first learned of the University of Phoenix and how she made that decision. She replied:

A family member was attending the university at the time, and I was struggling trying to finish my degree at the state university. So she put me in contact with her academic advisor at the University of Phoenix. I didn't consider any other schools and just enrolled.

Amy's response demonstrated that her decision did not involve consideration for other institutions. She was already enrolled at a public institution and she was not performing well, academically. Like the above-mentioned participants, Amy had that trust in her family member and seriously regarded their referral and institutional experience on which to base her decision. Other participants who transferred from a traditional non-profit institution offered a different perspective in their narrative. Sara and Tiffany, who had previously attended traditional non-profit colleges expressed that the service they received from their for-profit college was prompt unlike the run-around or "shuffling" they experienced at a larger non-profit institution.

Three participants were not referred or recommended by someone they knew. As an employee of the Art Institute, Kate was aware of Brown-Mackie College and Argosy University because the institutions were owned by the same parent company. Therefore, Kate's decision to attend Brown-Mackie College and Argosy University was reasonable, since she possessed insider information about each institution, coupled with tuition benefits. Linda and Helen conducted a Google search and found the University of Phoenix and the Art Institute of Miami, respectively. Linda considered the University of 
Phoenix because she learned that she would not be admitted to the public state university where she worked due to her undergraduate grade point average. Helen realized that she could pursue interior design and attend the Art Institute and the proximity of the campus to her apartment in Miami made it an easy decision for her.

In addition to being referred or recommended, participants expressed other factors that influenced their decisions to enroll at a for-profit college. When determining forprofit college choice, participants considered factors that were in alignment with their lifestyle, work schedule, and family obligation. For example, Rachel recounted how she was able to attend courses at AIU and Everest University while maintaining full-time employment:

[At AIU] I was working full-time but they accommodated my schedule for school. Because then when I decided to leave my previous employer and go to Everest during that timeframe, they accepted knowing that I'm going to be an employee, but my schedule has to be accommodated to attend school. Every semester they would accommodate my schedule for me. I enjoyed working at Everest because the teachers as well as the staff worked with me because I was working full-time. I mean go to class at night, my coworkers covered for me and assisted me. So, the Dean, the director, the campus president, they were all working to assist me to that one common goal they all wanted me graduate.

Rachel's employers agreed to adjust her schedule to allow her to attend class and work with her school schedule. Evidently, the research participants sought programs that would not interfere or be in direct conflict with their full-time job. In another example, 
Michael specified that the online format gave him "control" of how he pursued his degree with minimal interference of his law career.

Within the participant's narratives, many sought programs that were "flexible," which emerged as a key word. Participants expressed that "flexibility" of the online course format influenced the decision to enroll at the for-profit college where they ultimately graduated. Nicole, who was referred by a cousin who recently graduated, expressed that the University of Phoenix offered the "flexibility" that she needed, "Maybe for me, the word flexible was the key." The "flexibility" component that online programs provided was especially key to parents of young children. Nicole stated, "Okay, I can go to school when everyone's sleeping. And that's really how it ended up being." Similar to Nicole, Victoria, who was referred by her best friend, indicated that the online program at DeVry University "allowed me the flexibility that I needed as an at-home mom." Additionally, the concept of "time" with respect to parental responsibilities was also indicated as a factor for the desired course format (online, hybrid, or in person format) of the FPCU student. As Sara stated that she pursued her bachelor's online because she was working mother, "What attracted me from the beginning, was having the flexibility to do a whole degree online on my time."

Campus location served as a deciding factor for some participants. Kate, Helen, and Rachel, indicated that their campus location was close in proximity to their residence or work, which added to their decision to enroll at the FPCU. Kate attended classes in the same location that she worked. "The classes started at 6:00, so I would finish at 5:00, my job, and then start classes at 6:00. Thankfully, I didn't have to drive anywhere because it was in the same building." 
Access to career opportunities emerged as a major theme as this rationale was present in the majority of the participants' narratives regardless of their occupational standing. Acquiring and furthering their education in the form of a college degree was deemed to provide the access to the desired professional and employment objectives. With respect to how participants decided on selecting a for-profit college, this process occurred after determining to obtain a degree. Most of the study participants were referred to their for-profit college and considered factors such as "flexibility" and campus proximity. Although time to completion is present in the FPCU research as discussed in Chapter Two, participants Kim and Sara mentioned that this was a factor in their decision to attend a for-profit college. However, the research participants regarded their work schedule and convenience as substantial components that influenced their decision to attend a for-profit college.

\section{Student Support}

The for-profit student experience component of this study primarily centered on student support and services. Participants described their experience and the services that were available. If their program was online, the participants described their experience in terms of their semester schedule, whether their courses were eight weeks or five weeks in length. They also mentioned having to submit discussion posts in the online forum for their courses and meeting deadlines. For the participants that attended in-person courses, they described their student experience in terms of class size and schedule. However, the emerging theme that repeatedly was present within the participant experience was professor assistance, quality, and support. 
Concerning student support and services of the participant experience as an FPCU student, nine out of 12 participants reported that professor support and quality was a positive attribute. A majority of the participants indicated that professors were available and responded quickly to their questions and concerns. Five out of the 12 participants reported that they felt "supported" and "encouraged" by their academic advisors. In addition, the participants indicated that the support and outreach they received from their school was a strength and component at which their for-profit colleges excelled.

The participants that experienced in-person courses shared a sentiment of professor support and influence. Linda, who graduated from a large state university mentioned, "We got to know more about the professor and have a rapport with them on a day-to-day basis." This was due to the small and intimate class settings. Kim stated that while at Brown Mackie College, she changed her major from business administration to accounting because her professor was "so engaged and dynamic." Kim recalled her experience:

I started out just as a regular business major until I took my first accounting class. I didn't know anything about accounting. But the way this professor was so excited about accounting, made me get excited about accounting. Now if you know anything about accounting, it's not an easy subject. But he was able to break it down in a way that was so interesting. He was so engaged and dynamic with how he taught. It was that class that made me fall in love with accounting. From that class, I changed my major to accounting and have been doing it since. That was one teacher that I never forgot about. 
While at DeVry University pursuing her bachelor's degree (in-person), it was through a professor that Kim was aware of the Accounting Club and she was able to network with other students with similar interests. Kim's perspective as being the only participant who attended a for-profit college upon graduating from high school is worth noting. She may have been accustomed to small class settings and was able to establish a connection with an instructor.

In addition to professor rapport and support, study participants addressed instructor quality. Rachel explained how she felt about her professors at American Intercontinental University (AIU), a degree which she completed in both in-person and in hybrid format:

They had very good instructors. Their instructors actually cared. They actually wanted to teach. As far as the programs go. The programs I think that they were just more that the curriculum has to offer you in order for you to obtain your degree. The instructors were what made it worthwhile for me.

Rachel described that her instructors genuinely cared and she found that to be more valuable than the curriculum. Participants who pursued their degree online described their experiences from their professors and advisors. When I asked Nicole to describe the strength of the University of Phoenix, she indicated that she always had access to her instructors whenever she needed them and elaborated:

For me at the time, I never felt I lacked instruction. Although I've always been a people person and there was times where I'm like, 'Oh I wish I was in a classroom because I want to see people, I want to be able to really 
understand what my teacher's saying.' Or maybe not understand but engage more. I don't think I ever was, 'Ugh, I wish they had this.' Or, 'I'm not happy with this.' I don't recall ever having a really big complaint. I knew what I was getting myself into, right? I knew it was an online school. And because it was online school, I wasn't going to have certain things. There was a lot of things that I could have done that I didn't. They had a lot like seminars and workshops. I have to be honest. I didn't do a lot of them. I didn't make time for a lot of them because they took time and I just, I didn't make time for them. But I know that the school did offer those things. My experience with all my instructors was a strength of the university. They follow through with the guidelines. So I don't know if that was a management thing? I don't know if it was people on top of them? I don't recall ever saying, 'They're not replying to me.' I knew that there were certain guidelines that I was expecting from them and they always followed through. I was never like, 'Oh this teacher' and I had a lot, I went to school for three years. But I think their follow through with their guidelines.

Nicole did not mention quality of instruction but rather the responsiveness of her instructors. Michael expressed that he thought that professor availability was a strength of Strayer University. He mentioned, "I will say that the professors seemed to be available. If you emailed them, they seemed to respond quickly." Sara indicated that she did not want to rely on the fact that her spouse worked at DeVry University for support but she 
did encounter instructors that supported her. She shared her perspective regarding instructors at DeVry University:

We had the same quality teachers that you find here at [private four-year college]. You get teachers who if anything are probably even more helpful than the ones here, because I had a horrible experience at [private fouryear college]. You get the quality of hands-on to be with them, if you need to talk to them. They give you their cellphone numbers. I'm like, 'Come on.' Where do you see that nowadays?

Sara indicated that not only were professors accessible, but also they were experts and practitioners in the business field. She also mentioned the quality of her instructors and that some of her instructors were also adjuncts at the private non-profit institution where she is employed. She considered the fact that her instructors at DeVry were also instructors at the private non-profit institution a strength of the DeVry and indication of quality. Instructor experience in their respective industry, outside the classroom, was considered a positive attribute. Victoria shared her professor experience as follows:

The professors were awesome. Overall, they were very interactive. All the professors that we had, they all were working in the field that they were teaching in, every single one of them. They all brought life experiences to the table, which made a very big difference in how I viewed the class. Not just the content from the textbooks that we were getting, but the feedback that I was getting back from them because this is somebody that's already doing it versus me trying to get there. I really respected what they had to say. 
Engagement and communication from advisors was another support factor that the participants received. Participants expressed that there was "constant communication" from their advisors. During the start of every term either participants would receive a call or email from the advisor checking-in or reminding them to submit a post online. Other communication would refer to upcoming and available seminars students could attend inperson or remotely. Tiffany detailed the support she received from her advisor during her online program at the University of Phoenix:

And I'll tell you, University of Phoenix is very hands on. They're always making sure, is there something we can do? Is there something we can change? Is there something you need? So I think that helps the student a lot, to push them to say hey, I can do this because I have support. That was my main thing, having support. Because I don't have a lot of family here, or close family. It's just me and my children. So you know, my children are young, from age 1 to 14 . However, they support me. But having that extra support, it helped me.

Tiffany described and appreciated the outreach she received during her studies. For Tiffany, she utilized that support and took advantage of the outreach. She expressed that she has little support being a single mother and so the support and encouragement she receives from the University of Phoenix motivates her to continue her studies.

Contrary to the majority of the participants, Helen and Amy did not experience the same level of professor support or quality. Helen, who graduated 
from the Art Institute of Miami, had strong feelings about the professors. When I asked about her what the Art Institute could have done better, Helen expressed: Well, choose better professors because we pay a lot. They rely on a few professors for many different classes. You know, like one professor takes like six classes, six different classes. So maybe the university trusts them a lot? But really some of them weren't that good at it. And in careers like design, any kind of design, you can't, as a professor, you can't stop people from thinking and flying and being creative. So you never say, 'Hey, you don't do that.' No, because we have seen a lot of crazy things going on. And those famous designers never took no for an answer. So that's something that they [the instructors] hold you back. They didn't let you be as creative as you could be.

During her tenure at the Art Institute of Miami, Helen explained that the college relied too heavily on a small number of professors. As a creative, Helen wanted to be free to takes risks with designs. She mentioned that for a college where creativity should be encouraged, many of her professors were stifling. In addition, Amy, who graduated from the University of Phoenix, stated that she did not get to know the instructors. She stated:

Outside of the classroom, we really didn't have any kind of contact with the instructors. We didn't get to know our instructors very well. I mean, in my experience, I didn't get to know any of my instructors. In each class you had to do an introductory bio, in which where you gave them a little bit of information about yourself. The professor would give their biographical data telling us a little bit about them. And then that was it. 
Other than that, it's participating, submitting the assignments, and that was

it.

For Amy she was able to make a connection with her classmates throughout her program and she was indifferent to the professor support component. It is important to note here that in both Helen and Amy's perspective, the lack of professor support and quality did not significantly impact their student experience. Both participants stated to have had positive student experiences, despite their perspective of professor support and quality.

Except for Helen and Amy, it is evident that the research participants found professor support and quality as significant components of their experience. The outreach services from their professor, advisor, and institution administration were present in the majority of the participants' accounts. The participants expressed that they felt their instructors cared about them and appreciated the outreach and engagement from their advisors. Participants expressed that they felt "supported" throughout their for-profit college journey.

\section{Degrees of Impact and Satisfaction}

The study participants described the outcome of obtaining a degree from a forprofit college or university and outlined their specific experience post-graduation up to their current employment standing and to what extent were participants satisfied with their experience. Most of the participants' post-graduation experiences include promotion, salary increase, and/or career advancement opportunities, although not immediately after graduation. However, some participants have yet to secure financial gains and career progression, after five years or more post-graduation. Other participants 
did not specify if their degree impacted their career but alluded to their overall experience as an FPCU student. This section details the post-graduation outcomes of the research participants and addresses their perception of satisfaction as a result of earning an academic credential from a for-profit college or university. The satisfaction component refers to the extent to which the participants were satisfied with their academic credential. Additionally, the participants specify and summarize their culminating experiences.

Seven participants described the impact of their degree as a "promotion" or career advancement within their respective field. Evidently, these seven participants experienced career progression as a direct result after earning a degree and indicate as such. In some cases, some participants mention that along the career progression path, they encountered hardships and feelings of frustration and disappointment. Other participants indicate that they continued to seek promotions and opportunities.

Kate started her career in higher education as an administrative assistant at the Art Institute of Miami. After earning her associate's degree from Brown Mackie College, she was approached by management to apply for a student employment advisor position. "I was looking to move forward and make a little bit more money, so this opportunity came along and it was within my department, so I took it." Kate obtained a promotion and prior to earning her bachelor's degree from Argosy Online, she was approached again by management to apply for a career services advisor position, which she held for a number of years before transitioning to the career services manager position she now holds at a non-profit private university in Miami, Florida. When I asked Kate to summarize her experience, she stated, "For me, I had overall a good experience. Especially that I didn't have to pay for it, so that's a plus." 
Sara was working as an entry-level administrator at a private non-profit university in Miami, Florida while enrolled at DeVry University. She decided to pursue a degree at DeVry University for her "personal fulfillment" and because having a degree would expand her career options and opportunities. Sara described her feelings upon graduating as follows:

I know it wasn't going to do anything different at the university. Like, how people perceive it. For example, my dad, 'Now you have a degree, now you can make more money.' I'm like, 'Nah, it doesn't work that way.' I did however intend to apply to different departments within the university and other institutions. I did get several interviews. And even with the degree, it was mostly like, 'We don't have the budget, or we can't afford it. We can't pay more than this.'

Post-graduation, Sara experienced feelings of discouragement and stated that she was overlooked for opportunities within her department. She did take a lateral position within her unit and three years after acquiring her bachelor's degree, she was promoted to assistant registrar. She mentioned that obtaining the degree made her a more confident person. Although Sara indicated that she is happy in this new role and is embracing leadership, she is not where she wants to be salary-wise. Sara expressed:

Now I'm noticing a difference in this position, and that's why I feel with the salary that we are super underpaid. Very. And it's very sad, and I feel like sometimes that [pause] I don't know. People ask me, ‘So why are you still here?' My office, regardless, we're all like family. We go ups and downs. We all have our things. I love the environment that we've created 
here. Family-oriented. I know it from head to toe. I've done every single little thing here. What helps me too is I'm familiar with it, I'm happy. I wish I could make more money. But things are so much more expensive now. If that's one thing I could change, I will, and I think that's what drives me now to keep applying to other positions, because I need to think about my family. I'm grateful that I got this position, but I feel that it was a little underpaid. I feel like the salary is just based it off of something that they thought it was going to be, and they don't do the job, and they don't know what it entails. You know what I mean? I wish it was different that in that aspect.

Sara enjoys her position and work environment, but she desires a higher salary. During this portion of the interview, Sara seemed conflicted. She clearly desires and thinks she deserves a salary increase, but she also mentioned that she is comfortable in her position. Sara believes that she was able to secure a promotion due to her experience and academic degree. She continues to seek out and apply for higher positions. She summarized her feelings on the impact her degree has made:

As far as I think degree, I see the benefits because now a lot of places are asking for qualifications of a bachelor's or master's degree to even consider your application. That makes me feel, 'Okay, I have that down, and thank goodness.' But I haven't truly experienced the outside of it, because I've been in this office. 
Sara expressed that she is more confident but has not yet experienced her full potential because she has remained in the same department. She recognized that meeting minimum qualifications is one less item she has to worry about in her job search. Like Sara, Nicole's job search post-graduation was challenging.

Nicole was working from home for an online company and was a seasonal employee for the local department of elections in South Florida while she was a University of Phoenix student. Prior to enrolling at the University of Phoenix, Nicole worked in the healthcare management field. About one-year after completing her bachelor's degree in healthcare management, she assumed a position as an office manager for an orthodontist. She had previously worked there as the front desk receptionist. After a year and a half as the office manager, she was afforded the opportunity to become the administrative director for an autism clinic. She stated: I mean if it weren't for my degree, I wouldn't be in the position that I am now and earning the money that I'm earning now because of the kind of boss that I have, who values a degree and who values education. And so even though the first year of my management life wasn't that great, I also feel like I need that. I learned so much about myself and my strengths and my weaknesses. And what it takes to manage an office and the in's and the outs. So, my education paired with my experience at the oral surgeon's office helped me be who I am today in this position, a leader, grounded. So, it's kind of loaded, right? Because there's the worth, right? What I'm worth. And everything people say that a degree does, I've experienced. I know not everybody had that same experience. 
There was a sense of accomplishment that Nicole exhibited during her interview. She credited her current employment status to her degree and years of experience within the healthcare industry. Nicole possessed that awareness that degrees do not necessarily result in dream jobs or elevated status and was grateful that in her circumstance, she was able to reach her desired outcome. Nicole summarized her overall FPCU experience:

I would describe it as positive. I would recommend it to people. I have recommended it to people. I have been honest about it being very expensive. I have been honest about it being a big sacrifice, in terms of the time you have to put into it. But if it's something that you want to do, like you really want to accomplish, like you really want to, I would say it was a positive experience on my end. And by positive, meaning the outcome. Sometimes even something that's good has its hard, rough times during the middle of it but then afterwards it was worth it, like everything. So, I would say my experience was positive.

Nicole recounted her experience and described it as a positive experience, although it was expensive. She was referred to the institution and would refer others. For Nicole, she perceived her FPCU experience as a sacrifice in order to better herself. However, she was determined to reach her goal and found value in that pursuit and the outcome. Like Nicole, Michael was able to achieve his desired objective.

As an established practicing attorney, Michael decided to pursue a master's degree in public administration (MPA) to obtain a university level teaching position. He expressed that the outcome of obtaining a graduate degree from Strayer University provided: 
Because I had that degree (MPA), they got me back through the door and I taught American National Government on a consistent basis at, I want to say, two different campuses for three or four different semesters. It (the degree) opened the door. I knew I needed it in order for it to open the door, so that way I could teach.

The outcome Michael sought after earning a graduate degree from Strayer University was achieved. He secured a consistent teaching position and summarized his overall experience as either positive or negative:

I guess my overall experience was that it gave me what I wanted, allowed me to do it the way that I wanted to do. It was like, 'I'm going to give you what you need, which is this money, and you give me what I need, which is a degree.' So it was an even swap, no swindle. It was a quid pro quo. It worked perfectly for me as a student.

Michael was uninterested in the traditional academic route of becoming a researcher or law professor. Prior to completing his master's degree, he began teaching courses such as American National Government at the undergraduate level. He stated that Strayer University provided the means to teach at the undergraduate level without interrupting his law career. For Michael, the degree from Strayer University was a means to an end; it was transactional and supplementary. For other participants, however, the outcome provided the primary route for career advancement and/or financial incentives.

Amy was employed as program assistant at the public state university in South Florida while enrolled at the University of Phoenix. As a benefit, the public state university offers employees monetary incentives upon earning collegiate degrees. She 
was awarded a monetary incentive after earning her associate's and bachelor's degrees from the University of Phoenix. In 2016, she was promoted after obtaining her bachelor's degree. She stated that her applications for higher paying positions have not been reviewed because she did not possess a master's degree. She is expected to complete her master's degree in public administration by December 2019. She stated, "I believe if I do apply for a higher position, I will qualify for it, and that my application just won't get denied on an instant."

At the time of enrollment and during her online graduate program at DeVry University, Victoria was a stay at home parent. Her husband was in the military and because the family relocated frequently, Victoria was unable to establish a stable career. Additionally, she wanted to merge her criminal justice background with the accounting and finance industry. Her main goal upon graduating was to obtain a position with the federal government; however, that proved to be challenging. She described her postgraduation and employment search as follows:

I found it so hard. I used their (DeVry University's) resume service that the school had. They had job fairs that they offered, and they also had resume builders and things like that. I was still an at-home mom. I was still concerned about being full-time in the workforce with having small children. I was still not $100 \%$ onboard on going out and being a full-time worker and having a family. I did a little bit of applications that I put out there, but I don't think I was serious about it until about 2014, which is what, three years later. I didn't even get one bite on any of my resumes after I graduated. I put out quite a few but, again, I was just putting out 
random stuff. I was just trying to get my foot in the door. It would keep coming back with not qualified or qualified, not recommended because I have a degree, I didn't have the experience. That was the toughest thing for me. I could not get my foot in the door. One, because I wasn't trying online. I wasn't pushing myself to go out there. All the jobs that I was applying for were federal jobs. I did limit myself because of how often we move.

After volunteering at her local church's office as a bookkeeper, she was offered a full-time position at her church. It was after the family relocated from Florida to New York that Victoria secured employment with a credit union, three years post-graduation. She expressed that “I feel like if I didn't have it (master's degree), I wouldn't have the job that I have now." Victoria has been able to transfer to three branches and now works at a branch in Central Florida. When asked about her culminating experience, Victoria stated:

I really don't have anything negative to say about DeVry. My experience with them was great. Let me tell you I can nitpick. I can if I had to. Yeah. I really don't have much to say because the one thing that I found an issue with was with my other school. I could compare them with Columbia in that my classes weren't always available. I would either have to settle for one class or wait the whole nine months before it became available again. With the online classes, at DeVry, there was a couple classes that you would have to wait for, but they would never hold you up for graduation because of it. Like, it would become available, maybe, next semester. You wouldn't have to wait a whole school year for it to come back 
around again because you just missed it, or it's conflicting with another class that you need to take. I found the online courses gave me that flexibility, for sure, where I wasn't limited. I just took my time getting my degree because I was an athome mom. I didn't always go to school during the summer, which I could, but I had four semesters in a year. I was able to finish in a decent time. I just drug it out because I had other important things. Yeah, they were awesome. You can't even pay me to say something negative.

Victoria summarized her experience within a positive connotation and emphasized that although there were issues, she valued her experience. DeVry University provided a convenient avenue for her to obtain a degree without changing her lifestyle, being a stay-at-home parent. She placed value on the flexibility and did not have to compromise much to reach her ultimate objective, while pursuing her degree.

Unlike the majority of the research participants, Kim started college immediately after high school and did not have any previous professional work experience. After earning her associate's degree in accounting from Brown Mackie College, she was unable to secure employment in her desired field. She described her post-graduate experience and employment outcomes as "frustrating and disappointing" saying:

I had to work as an income tax preparer for Jackson Hewitt during tax season. I did some odd jobs here and there and I also worked in retail. I could not get an accounting job at all. I couldn't find a job to save my life. No one knew about Brown Mackie College and I always had to explain that it was a private school. But no one knew about it. Finally, after I got 
my degree from DeVry, I was able to get an entry level job with a CPA firm as an accountant. I found that job through Craigslist. Upon graduating from DeVry University and after a few years with the CPA firm, Kim transitioned to a private charter company with an internal accounting department. She exclaimed, "It has not been easy, but at least I am in my field with a good company." She does not plan to further her education with a graduate degree. Kim graduated from two for-profit colleges and seemed to have both positive and negative experiences. When asked to summarize her experiences, she stated:

That's hard to answer. I guess overall it was a good experience, but I had so many problems after graduating from Brown-Mackie. It was a very difficult time to try to get a job. While I was a student there, it was fine. I thought the school was fine but after was a different story. When I was at DeVry, it started off good too but then I ran into problems with my financial aid and had to take classes at Miami-Dade College. The dean at DeVry helped me to transfer my credits but when it was time for graduation, they told me I had to take more classes which was just frustrating. But I was able to fix that. I mean to answer your question, I think I had a good experience overall and I am glad I got my degrees. I wouldn't have the job that I have now in accounting without it.

Kim expressed that although there were difficulties associated with her experiences, overall, she recognized that her employment status is attributed to her degrees. During her interview, Kim communicated her feelings of frustration and disappointment. However, she also demonstrated that she enjoys her field in accounting. 
Kim also alluded to the financial challenges she faced and I discuss this in more detail in the following fourth theme.

Three participants have not yet experienced career advancement or secured a promotion. The following indicates the reasons the participants have not yet encountered professional growth post-graduation as obtained through their narratives. I also include their overall perspective and demonstrate the extent of their satisfaction of their FPCU experience as this provides additional insight related to their outcome. It is important to note that the three participants are African-American women ranging from 35-45 years of age. In addition, these three study participants are employed at three different institutions of higher education in South Florida: private non-profit, public non-profit, and private for-profit respectively. Two of the non-promoted participants hold a master's degree in business administration (MBA), while one participant is currently enrolled in a master's program. Tiffany, Linda, and Rachel indicated that they have yet to obtain their desired employment outcome. During their interviews, Linda and Rachel expressed their frustration and explained that their degree has not had an impact on their career prospects.

Tiffany has been employed as an entry-level records keeper at a non-profit private university in South Florida since 2016. She enrolled at the University of Phoenix to establish and progress in a career within the education field. At first, she wanted to become a teacher since she was an after-care teacher. However, after securing employment at the private university, she realized that a business degree would provide broader opportunities. She has earned an associate's degree in education and a bachelor's degree in business from the University of Phoenix. She is currently working on a 
master's degree in adult education at the University of Phoenix. Tiffany summarized her FPCU experience:

I think it's the best decision I made. I think that my experience with them has been, honestly, for me life changing. It may be small to others, but for me it was life changing. It gave me confidence. It gave me, I think, just self-worth. I mean, because I was in a bad place, but like I said, that support team was amazing. They let me know I could do it. I didn't have my parents. My mom, my dad passed away. I didn't have anybody to say, 'You can do this. You got this.' Nobody told me that. They did. University of Phoenix told me that. You can do this. So many times I said I couldn't, but they told me I could, and I'm doing it. I'm very happy. Although Tiffany has not yet secured a promotion, she is content in her current position, as it allows her to focus on her coursework. Her objective is to obtain a doctorate degree in adult education and she wants to become a professor and teach at the university level. She summarized how she decided on her career path:

Like I said before, I wanted to be a teacher. And then it changed to, okay, now I'm in business. I was really stagnated. I was like here and there as far as career wise. I didn’t know, actually, what I wanted to do, pretty much a set career. I didn't have one. I did not have one even up until graduating with my bachelor's. I didn't have one. But I have one now. I have one in mind. I would love to be a professor at an accredited university teaching adult learners. That is my goal. Although Tiffany has not actively sought career advancement opportunities at the university where she is employed, she stated that she is happy and has her goal in mind. 
She expressed that at one point in her life, she did not consider going to college; she was "afraid of the college life." However, she is no longer afraid and enjoys the "college life." She stated that she wants to be a model for her children and be better for them and herself. She views her current position as part of the journey and plans to reach her goal of becoming a professor.

In contrast to Tiffany, Linda has attempted to secure promotions and career advancement at the public university where she is employed as an entry-level administrator, to no avail. She earned an MBA from the University of Phoenix in 2009 and received a monetary incentive upon earning her degree. Linda stated that although earning her graduate degree has helped to strengthen her technical skills and abilities, she has yet to secure a promotion. She expressed her disappointment and recalled:

I remember one of my, professors were saying that you, once you get a master's or like an MBA, that would start you out at $\$ 60,000$. I did apply to different places, but still, I didn't get [the salary] what was expected. But I'm still, I'm trying to get through that, but that kind of is disappointing me, getting the degree and then not like fulfilling that yet. Linda's main goal is to become an entrepreneur and establish her footwear company. She expressed that she has yet to realize this goal and utilize her business degree. She stated "I just need to stop being lazy and implement what I learned." When asked what she would want readers of this research to know she elaborated:

Basically, like, whatever, even though it's been 10 years, I have it. I know I want to use it somehow, and I just need to stop being complacent and do what I need to do in order to fulfill my goal as far as owning my own 
business, implement what I've learned throughout getting my degree.

Yeah, so that's basically it.

Similar to Linda, Rachel has not yet encountered professional advancement although she has continued her search. She obtained an associate's and bachelor's degree from American Intercontinental University and an MBA degree from Everest University. She is employed at a for-profit college as a mid-level administrator and expressed the following disappointment in her career search:

I have been applying for the last three years straight. I've probably gotten maybe a handful of phone calls and those handful of phone calls were for about the salary ranges from anywhere from $\$ 35,000$ to about $\$ 45,000$. I didn't go to school to owe $\$ 100,000$ in debt to work for $\$ 45,000$ a year.

She indicated that although she has "applied everywhere" and has updated her resume, she has been "overlooked" for positions for which she is qualified because of her race. She stated that her "qualifications supersede their qualifications" and because she is African-American, she has not been able to move up in the higher education field. She has searched for positions in for-profit colleges and non-profit colleges. However, she has remained at the same level for years with minimal prospects of "moving up." She expressed that she is unable to uproot her children to relocate for "better" career opportunities. Rachel mentioned that she thought once she earned her MBA, she would easily transition into a "corporate job." However, she has faced challenges and difficulties in advancing her career.

There were two participants who were seemingly un-impacted from a career perspective. Helen was an international student who earned a bachelor's degree in 
interior design from the Art Institute of Miami. After graduation she participated in an international student benefit called Optional Practical Training, OPT. This benefit permits international students to work in the United States for 12 months in their academic field. As a result, Helen worked for a partner interior design company. After one year, she returned to Panama where she currently resides and occasionally visits her son in Miami, Florida. She currently works for her son's real estate investment company on a part-time basis from Panama. Her main objective in pursuing her bachelor's degree at the Art Institute was to remain in the United States. Therefore, she was not interested in pursuing a professional career in interior design, although she had done some interior design unofficially in Venezuela, her home country.

Diane's post-graduation experience may rely mostly on her work experience rather than on her credentials. She stated:

For me, I had done everything in the area which I work. I had held all the positions except for director. So, my hope was that it would help in me becoming a director, or greater, at some point to have a master's degree. It came to fruition, but I don't know if my master's, I can't say that it helped. Maybe it did. My situation is a little different because when I became a director, it was under an administrator that was very racist. And so financially it did not, it didn't matter. I got the director title, but I didn't get the money that comes with it. So, I don't, I think that was more him than it was, my credentials show that I should have been. So it's hard to call whether or not it benefited. I know some directors in my profession that don't have master's degrees. So, I can only assume it helps. 
Diane, who is employed at a private non-profit university, indicated that although she was promoted to director four years after earning a master's degree in public administration from Strayer University, she could not say whether her degree played a role in her promotion. In this context, Diane alludes that her graduate degree may have helped her achieve a higher title, but she did not necessarily experience a promotion in title, compensation, and responsibilities. During this segment of Diane's interview, she seemed indifferent to the experience, yet accepted the fact that she believed she was racially discriminated against.

Within this theme, participants described how they perceived their degree impacted their career outlooks, including any financial incentives. Seven participants were promoted and explained that they either secured employment in their desired field and/or "moved up" in their position. In contrast, three participants were not promoted and indicated that they have not yet been able to experience career progression opportunities. Two participants did not attribute their earned degree to any career advancement or decline. The financial component in terms of the post-graduation experience is discussed as this relates to how the participants viewed their for-profit experience from a value and cost perspective.

\section{Return on Investment}

The fourth theme which emerged from this research study centered around the financial investment participants made on their higher education credential. The study participants expressed how they valued their degree and addressed financial expenses associated with obtaining their degree. The following outlines the financial component of 
earning an FPCU degree and the research participants' overall perspectives of their academic experience and/or degree.

All but three participants received federal financial assistance and took out student loans while enrolled at their respective FPCU. Kate received tuition remission benefits since she was an employee of the Art Institute of Miami. She did not incur tuition costs, but she was obligated to pay income taxes as a result of the tuition remission benefit. She indicated, "Well, the cost was basically free for me. I only had to pay the taxes, I believe at the end of the year. So, it was basically free of charge, so I had to take the opportunity." She also mentioned that she would not be where she is now professionally without her degrees. She summarized her experience at both Brown Mackie College and Argosy University as follows:

I had a, like I said, a good experience. I mean they're smaller schools. They're not huge like the non-profit, like traditional schools. So, I think they give a little bit more attention to their students versus like you're on your own in the other university. They're like okay, here are your classes, go ahead and register yourself. So here it was more like personal attention. Kate is now employed for a well-known non-profit private institution in the career services field. Her financial investment was minimal, as compared to other participants. She leveraged her employment benefits to achieve professional growth. Similar to Kate, Sara was able to use her spouse's employee benefits to supplement her tuition costs. Since her spouse was an employee of DeVry University, she also received tuition waivers during her enrollment at DeVry University. She stated that she is happy and is proud to have attended DeVry University. She exclaimed: 
I want to put it on the wall. I want to show that it is worth it, and it is just as good as (other universities). But that stigma of, 'Oh, you're not at this school, or because you're not at that school; they're not big enough.' I wish that wasn't the case, and I feel like maybe DeVry should do better on reaching out more and saying, 'We can be that. We could do that. We can do that. We have people.' I don't know, like me. I would be willing to be on a commercial if I have to, because it was a great experience.

During Sara's interview, she demonstrated pride and genuine happiness when she spoke about her experience at DeVry University. Her degree is encased in a frame and hangs in her office. She is aware of the negative stigma for-profits carry; however, she insists that the notoriety does not diminish the value of her degree.

As an international student, Helen was ineligible for federal financial assistance. She did not incur any student loans and paid for her program completely out of pocket, totaling about $\$ 100,000$ for her bachelor's degree in interior design. She summarized her experience as "fun" and was aware that she is privileged to be able to afford the cost of tuition, as she knew many other students who needed financial assistance.

The remaining nine participants stipulated that they needed financial aid in order to attend school. Some participants specified that they sometimes took out more student loans than they needed to cover the living expenses, such as Diane and Victoria. Diane completed a graduate degree from Strayer University, which can cost approximately $\$ 30,000$ for tuition. She indicated that her total student loan debt (including her undergraduate degree) is upwards of $\$ 250,000$. She stated, "I borrowed what I could receive. I didn't borrow just for the purpose of covering my tuition." With respect to the 
degree value component, Diane mentioned that she does not "like" her degree and wishes that she had pursued another program. Victoria also indicated that she took out more student loans to pay for items other than tuition including "household expenses" while enrolled at DeVry University. In contrast to Diane, she mentioned that although she is "very satisfied" with her experience and degree from DeVry University, she wishes she did not borrow as much as she did. She stated that she has about $\$ 50,000$ student loan debt.

The student loan factor and cost of attendance was often described as "expensive" although many participants perceived to have had a positive experience overall and articulated that they valued their degree. Tiffany, who also has about $\$ 50,000$ in student loan debt, expressed that although she has incurred debt, she'd rather "pay back and be educated and get the job I want instead of settling for what I have to." Nicole who is in repayment status with about $\$ 60,000$ in student loan debt maintained that she had a positive experience, although her degree was "expensive." She expressed, "Sometimes even something that's good has its hard rough times during the middle of it, but then afterwards it was worth it, like everything." However, some participants voiced concerns regarding their student loan debt incurred from a for-profit college despite having a positive experience. For example, although Kim enjoys the accounting field and the benefit her bachelor's degree afforded her, she states that she regrets obtaining an associate's degree from Brown Mackie College. She says:

I really should have just gotten my bachelor's degree, that way I would have avoided loans, which I don't know how I am going to pay it off. I owe more than $\$ 40,000$ and the money I am making is not enough to 
cover my student loans. My student loans are way too much for this industry.

In addition, Linda, who graduated with an MBA from the University of Phoenix in 2009 , has over $\$ 30,000$ in student loans and is now in forbearance status and stated that her loans are a concern. Student loan companies place borrowers in forbearance status in the event that borrowers are temporarily unable to make monthly payments and interest still accrues on the student loan while in this status. She stated that she stopped paying her student loans at some point because she could not afford to pay, but she mentioned that she intends to start paying her loans. For Amy, she too is proud of her two degrees she earned from the University of Phoenix. However, she also expressed concerns about her student loan debt exceeding \$70,000. She said about her loans, "At the end of it, I'm going to be in debt. Oh my God. Yeah. It's going to be a lot. I don't know how I'm going to get out of it, but it's going to be a lot. I'm going to struggle."

With two undergraduate degrees from American Intercontinental University and an MBA from Everest University, Rachel expressed that she valued her education and received a quality education. However, her two major areas of concern related to how expensive her degrees were and not being able to obtain a higher salary and career advancement. She expressed her student loan distress as follows:

For me, the only thing that I can really say that baffles me is the expense. It's too expensive. It's not feasible for anyone to ever be able to pay off those loans. With the amount that they're charging students there's no way unless they're walking into jobs that are allowing them to make that money. They're not. No one can make that... I owe over $\$ 100,000$ right 
now in student loans, and by the time I pay that off, I probably will be a hundred years old. I think that my education was definitely worth [it], the content was actually worth my time and effort because I did learn. As far as grammar, speech, being able to properly communicate, being able to even remain in this industry as long as I have my education has assisted me in that. The only two things I would say was I wish it was not as expensive and I was able to obtain a salary that's feasible to my knowledge.

Rachel is seriously concerned about her student loan debt. She does maintain that she values her degrees. She believes that her credentials have helped her professionally but not quite financially. Rachel feels that the tuition expenses were too high in proportion to her career outcomes. She desires to grow professionally and financially; but she feels frustrated that her student loan debt does not match her current salary.

\section{Summary}

The main objective of this study was to explore and understand the comprehensive for-profit student experience from the pre-enrollment and the decision making stage throughout post-graduation. The first emergent theme centered on how participants made the decision to pursue a degree and why they made that decision. Most of the participants were referred to a for-profit college by a close acquaintance or family member. They also considered factors including the degree format and school location as a basis for their decision.

The participants expressed career prospects as the main catalyst for the decision to attend a for-profit college. They expressed a strong desire to either pivot career paths or 
strengthen their professional experience with an academic credential. Two participants took advantage of educational benefits and recognized that high typical cost associated with a college degree. Securing a stable career was another driving motivator for other participants, especially those with children and families.

Professor support and student outreach emerged as a pattern that the participants expressed while enrolled at the for-profit institution. Participants perceived professor support and quality as a positive attribute when they recalled their experience. Further, participants detailed how their earned credential(s) impacted their occupational standings and their overall sentiment of their post-graduation perspective. Finally, the financial investment in terms of student loans and tuition costs was an underlying theme with respect to the participant degree. As a result, the emergent themes appear to align with the study's research questions and I discuss the findings implications in the subsequent chapter. 


\section{CHAPTER VI}

\section{CONCLUSION}

The present study centered on the experiences of individuals who graduated from a for-profit college of university. The usual discourse and literature surrounding the forprofit higher education industry focuses on student-debt lawsuits, fraud allegations, and poor completion rates; rarely is the graduated student perspective garnered. Often the forprofit college industry is characterized as the antithesis of traditional higher education. Additionally, the lens in which the for-profit college sector is described is second or perhaps third tier. However, the research participants in the current study described how they came to their decision to attend a for-profit college, some indicating reasons of not choosing a traditional institutions. Nevertheless, the for-profit higher education industry persists through the notoriety, school closures, and government sanctions. To fully comprehend how the FPCU, for-profit college and university, manages to sustain enrollment, obtain accreditation, and ultimately stay in business, the student experience must be considered and not be neglected.

I chose to focus this study on FPCU alumni within the South Florida region. As mentioned in previous chapters of this dissertation, South Florida represents a unique geographical zone within a higher education context. There are at least five state colleges and universities along with at least five additional non-profit private institutions within this geographical region. However, there are at least a dozen operating for-profit institutions within this region as well. Despite the number and type of institutions within South Florida, I wanted to understand why students chose to attend a for-profit college. I wanted to explore not just their rationale but also their motivating factors that played a 
role in their decision-making process. I wanted to consider the why and how questions in this regard. Secondly, I wanted to address their student experience. How did they perceive their experience as an FPCU student? Often FPCU literature includes the narratives of those that did not complete or graduate from an FPCU. I intended to contribute to this discussion by incorporating the narratives of those who did graduate. Further, exploring why students made their school selection and what their experiences were seemed to stop short of full comprehension. My final research question centered on participants' post-graduation outcomes. What did they experience after earning a degree? Did participants secure their dream job? Did they continue their studies? What were the results of their degree, if any?

As I conducted this qualitative study, I relied on the education gospel as my theoretical framework throughout. The concept provided meaningful context to begin to understand why individuals chose to pursue a higher education. It helped me to objectively explore their experiences and attempt to conceptualize and make meaning out of their post-graduation experiences, outcomes, and overall perspective. The framework consists of a belief system that rationalizes a certain behavior, such as earning an academic credential for the purpose of employment gains.

Five participants did not experience employment gains or career progression postgraduation. As the data suggests the education gospel does not guarantee career or financial progress. The construct, therefore, is not a given. The participant postgraduation outcomes arguably demonstrates the fallacy of the education gospel. Grubb and Lazerson's (2004) concept presumes that a college credential equates to skills that cannot be acquired without a higher education. Although participants obtained a college 
degree, who can verify that they also acquired higher order skills? Employment gains as a result of academic credentials serve as a foundation for placing faith in the education gospel. But the concept does not explain how one could obtain a degree without reaping employment benefits. For example, Sara completed her post-secondary education at DeVry University and was promoted three years later. Although she was promoted, Sara indicated that she is underpaid and has not been able to secure a higher position.

Additionally, the education gospel concept does not address life and economic factors associated with obtaining a college degree such as student loan debt. For example, Linda indicated that she cannot afford her loan payments and is forbearance. Linda, who has stayed in the same position since graduating with an MBA from the University of Phoenix in 2009 incurred $\$ 30,000$ in student loan debt. Linda believed that she would get a better job and higher salary after graduating, neither has happened. The education gospel may describe why individuals choose to pursue a college degree, however, it stops short of including factors that may influence post-graduation outcomes.

The present study on for-profit college graduates aims to contribute to the overall research and literature of the for-profit college sector and the study of higher education as a whole. I have attempted to provide insight through personal narratives of FPCU graduates, an important but neglected group of individuals, within the higher education space. The anecdotal descriptions provided by the research participants support and contradict the research on the FPCU sector. However, the main objective was accomplished in that participants detailed their collegiate experience and willingly recounted their perspective, from the pre-enrollment phase throughout graduation. 
In the present chapter, I address each research question based on the participant narratives and include an analysis from my interpretation of the narratives. I highlight the central theme of the study, which rests on degree satisfaction and discuss how the findings impact the literature surrounding for-profit colleges and address the student loan debt scenario as it relates to FPCU research and higher education in the larger context. I then present the implications of this research study and include recommendations for future research on the for-profit college industry.

\section{Reasons for Attending an FPCU}

The first research question: Why did FPCU graduates choose to attend a for-profit college? The answer is simple: Students chose to attend a for-profit college because they wanted to. However, this answer is insufficient and does not warrant an entire research study. In truth, there are many answers and one answer is that research participants, the FPCU graduates, elected to attend a for-profit college because of various life factors at the time of their decision-making process. The prominent answer as depicted in the preceding chapter is that participants wanted access to additional and progressive career opportunities. Additionally, a family member, friend, or other known associate, who also attended or graduated from the for-profit college they referred, suggested the participant to look into the for-profit college. The findings suggest other rationales for pursuing a degree at an FPCU. For example, two participants stated that they decided to attend a forprofit college and obtain a degree because it was an expectation of their career field. One participant, Helen, enrolled at the Art Institute to remain in the country. While other supplemental rationale includes cost, it was essentially free to study at an FPCU due to employment benefits for two participants, Kate and Sara. 
Pivoting back to the primary indicator for why graduates chose to attend an FPCU, the majority of the participant narratives primarily center on the possibility of post-graduation employment prospects. Participants wanted "more" or "better" career outlooks during this stage of their lives. Their version of more, better, or other quantifiable descriptions meant that they had to or were required to pursue an academic credential. This idea goes back to the education gospel within American society. The notion of securing the American Dream including hard work and a degree is understood. Participants essentially stated that they wanted to progress and improve their circumstance for themselves and their children; they would aim to do so through employment gains as a result of earning academic credentials.

Another approach to answer this study's first research question is to consider Grubb and Lazerson's (2004) education gospel concept. Participants elected to attend an FPCU because of their faith in education and the benefits of an academic credential. Grubb and Lazerson's (2004) education gospel theory and practice is far more pervasive and blatant with the expansion of higher education since the $20^{\text {th }}$ century and today. Now more than ever, universities for-profit and non-profit are spending millions of dollars in advertising (Katzman, 2016). Graduating from college is pre-requisite for many entrylevel positions and as a couple of participants confirmed, is an expectation in certain fields, especially education.

Iloh and Tierney's (2014) qualitative research on for-profit college choice contributes to the discourse of the FPCU student experience. Their study was conducted with 75 FPCU students - not yet graduates - and they found that FPCU students conduct a cost-benefit analysis on which to base their decision (Iloh \& Tierney, 2014). Iloh and 
Tierney (2014) suggested that the cost to attend an FPCU was linked to perceived advantages, including time to completion, flexible course schedules and instructional quality. In contrast to Iloh and Tierney's research, the participants in this study did not consider a cost-benefit analysis. Time to degree completion was mentioned but not significantly present in the research study, among the majority of the participants. Rather, employment prospects and the referral factor are primary motivations behind participants' decision to attend a for-profit college. Although Iloh and Tierney's (2014) results differ than what the current research finding suggest, their study addresses the FPCU student perspective and offers a large sample of narratives to support their findings. Employment prospects, career outlooks and the trusted referral component serve as the driving impetus for the FPCU graduate.

Similar to the present study, Iloh and Tierny's (2014) research also found job outcomes and anticipated compensation as FPCU student choice factors. In short, there are many answers to why FPCU graduates chose to attend a for-profit institution. The findings suggest that students did so to elevate and achieve economic mobility through career advancement. The referral component solidified the participants' decisions and also helped to rationalize their decision. However, other relevant factors including cost and school proximity, are supported by research on the for-profit sector and contribute to the overall discourse.

Chung's (2012) research explored if students self-select into an FPCU or if outside forces influence student decision. Evidently, the research participants in Chung's (2012) study self-selected into a for-profit college and external factors did not significantly alter their decision. Chung's (2012) quantitative study, found that gender, if 
female, is a substantial component of FPCU student choice. Chung's (2012) finding on gender being a factor of FPCU student choice is consistent with the current study's research sample consisting of mostly female participants. This is not to mean that because someone is a female she will likely attend an FPCU because of her gender. Rather, Chung (2012) indicated that women are more likely to enroll at an FPCU due to the areas of academic discipline, such as the healthcare fields - in which women represent over 50 percent of the for-profit sample in Chung's study.

Women represent more than $60 \%$ of FPCU enrollment and are overly represented in the current research study (Arbeit \& Horn, 2017; Chung, 2012; Deming et al, 2013). The idea that women are more likely to self-select into a for-profit institution is relevant to the current study, as all of the research participants effectively self-selected due to their current life circumstance and perceived the FPCU as a viable option. The research participants all identified as a minority, either Black/African-American or Hispanic. Although not represented in Chung's (2012) study, race is recognized as a component of FPCU choice. Other factors, including age, are notable factors in FPCU choice and this research study reveals that the average participant age while enrolled was 32 years. All but one participant demonstrated work experience prior to enrollment and thus played a role in their decision to pursue professional advancement and employment prospects.

\section{FPCU Student Experience}

The second research question explored the FPCU student experience. What were the experiences of FPCU graduates in college? Although their experiences varied due to external and personal life factors, the research participants shared similar narratives of 
their student experience. For the majority of the participants who attended an FPCU virtually, their narratives were structured and sterile. They described their in-college experience by the online format or platform, detailed their course schedule and submission deadlines. However, a recurring narrative was the emphasis of flexibility. Participants who attended courses online repeatedly stated that they were able to work at their own pace and time. When I consider this segment of the participant narratives, I recall the efficient and technologically proficient characteristics of for-profits. For-profit institutions that primarily deliver online courses are "highly structured" with their curriculum and flex their adaptability with technological prowess (Deming et al., 2013). Research participants who attended their college in person claimed to have more professor contact, as expected. However, as reported in Chapter Four, professor and advisor support emerged as a recurring theme. The participant narratives included language that alluded to instructor responsiveness and availability. Respondents also indicated support and motivation from their advisor; verbiage such as check-in and outreach repeatedly recurred. It would be interesting to compare this experience with that of traditional university graduates. Within this scope, participants described their inperson courses as small or intimate settings. This representation was framed with positive emotion and intonation on behalf of the respondents. They seemed to have appreciated the professor-to-student relationship and recognized it as a strength of the institution. Within this scope of the participant narratives, I consider this aspect of the FPCU student experience to fall under the customer service and management principles for-profit schools engage in. The respondents framed their student experience from a service perspective. They described their experience in terms of professor accessibility, 
responsiveness, and engagement. Berg (2005) described this model as business-based customer service principles. Interestingly absent from the participant narratives were student support resources such as the library, tutoring, and/or writing workshops. The research participants did not utilize student services, although participants were aware of additional services. Iloh and Tierney's (2014) study concur with this sentiment. In their study on for-profit students, Iloh and Tierney (2014) found that students were more interested in institutional information such as accreditation rather than general student services.

\section{FPCU Post-Graduation Outcomes}

The final research question focused on the post-graduation experiences of the participants. I sought to obtain the detailed accounts and outcomes of the FPCU graduate experience not just to confirm or refute the literature, but also to add to the FPCU discourse overall. I wanted to examine their outcomes and learn about their experiences. Understanding the FPCU student experience and their post-graduation outcomes is an essential step prior to considering what can be done with this insightful information and how to apply it for future research.

The research participants detailed their post-graduate experience in terms of career advancement and employment gains. They specifically outlined how and if they were able to secure a promotion, another position, obtain monetary incentives, and effectively summarized their process up to their current status. Secondly and more importantly, the participants concluded and placed meaning on their overall experience in terms of satisfaction. The respondents indicated language that determined if they had a positive or negative experience. In essence, the research question, what were their post-graduate 
experiences, resulted in the respondents explaining or rationalizing if their degree was worth it and/or did they obtain what they wanted from the degree with the answer being, yes. In other words, through the detailing of their post-graduation experience, the respondents inadvertently answered the question pertaining to degree worth and value. This notion of degree satisfaction is discussed in more detail within this chapter.

\section{Degree Satisfaction}

A major takeaway from this research is that all respondents alluded to being satisfied with their FPCU experience, although for different reasons and at varying aspects of their experience. There were respondents who indicated being satisfied with the result of their FPCU degree in securing career growth and advancement opportunities and demonstrated the level of satisfaction of the experience. However, the findings do suggest that although some participants indicated that they were satisfied with their overall experience, they also encountered hardships and challenges.

Kate, who attended Brown-Mackie College and Argosy University, secured two promotions from her original employer and ultimately obtained a position at a traditional non-profit institution within the career services field. Kate stated, "Overall I had a good experience." She achieved financial and economic progression along with career advancement because of her academic credentials. Like Kate, Sara also indicated she feels "more confident" and "comfortable" with "all the qualifications." Overall, it is clear that she had a positive experience.

Sara, who graduated from DeVry University, was promoted within her department and displayed pride about earning her degree. In contrast to Kate's postgraduation experience at Brown-Mackie College and Sara's experience at DeVry 
University, Kim's post-graduation challenges may have influenced her overall level of satisfaction. Kim, a graduate from Brown-Mackie College and DeVry University, encountered employment challenges post-graduation and financial difficulties. Even though she secured a position within the accounting field, Kim expressed regret in her narrative and stated that she should have attended another institution rather than attending Brown-Mackie College and DeVry University. Similarly to Kim's post-graduation experience, Victoria, a graduate from DeVry University, struggled to secure employment. After a few years post-graduation, however, Victoria obtained a position within her desired field of banking. Even though there were challenges, Victoria expressed her level of satisfaction by stating that she was "very satisfied" and that she had a great experience with DeVry University.

As a graduate of the University of Phoenix, Nicole serves as the administrative director for a healthcare center and attributes her professional and financial success to the institution and her years of work experience. She indicated her level of satisfaction, that she had a positive experience, and that she recommends the institution. On the other hand, Linda, who also earned a degree from the University of Phoenix, has not yet achieved a promotion but her experience has helped her to grow. Though she is using her degree, Linda feels she needs "to do better as far as getting higher" and "finding a position that will benefit" her.

Linda stated that her degree has not affected her career and she is not utilizing her degree. She stated, "It was a good experience" and she recommends the university. For Linda, she is glad she earned the degree. However, she recognizes that her true passion lies in opening up her business and she just needs to implement it. Interestingly, Diane, 
who earned a graduate degree from Strayer University, stated that she did not know if her degree impacted her career and demonstrated doubt if it did. Unlike Linda, Diane was promoted a few years after earning her master's degree. However, her promotion at the time was in title only and not in compensation. Diane stated that her degree "served its purpose." She knew she wanted and needed a graduate degree but did not imply a level of satisfaction such as the other participants. Like Diane, Michael shared a similar sentiment, in that his degree served a purpose. However, Michael provided insight into his level of satisfaction post-graduation. Michael, the attorney who obtained a master's degree from Strayer University, consistently teaches at a for-profit institution while maintaining his law career. He exhibited his satisfaction by stating that Strayer University gave him the control he wanted in order to pursue his studies and earn a graduate degree. This enabled Michael to achieve his goal without sacrificing his time.

For Amy, she received financial incentives upon earning her associate's and bachelor's degrees from the University of Phoenix and was promoted upon graduating with her bachelor's degree as well. Amy stated that her degree "opened up doors" and she indicated that she plans to earn a master's degree for additional career advancement opportunities. Amy achieved one of her goals, which was promotion, and displayed satisfaction post-graduation. Contrary to Amy's experience, Tiffany has maintained the same position since enrolling and earning two degrees from the University of Phoenix. However, Tiffany exhibited her satisfaction and emphasized her positive outlook on her experience. Tiffany expressed, "I think it's the best decision I made. I think that my experience with them has been, honestly, for me life changing." Although she has yet to 
experience professional growth, Tiffany clearly is content with her experience and is continuing her education with the university.

Comparably, Helen also exhibited satisfaction with her experience at the Art Institute of Miami and expressed that she, too, had a good experience. She was able to travel, study, and spend time with her family in the United States. She described her experience as "fun" and had "no regrets." Rachel, who graduated from American Intercontinental University and Everest University, also demonstrated positive feelings towards her experience in that "the content was actually worth my time and effort" because she learned. However, Rachel, like Tiffany and Linda, has not achieved professional advancement yet. She communicated her frustration and expressed that her student-loan debt far exceeds her salary and that she has been unable to move up due to her race. Rachel, Tiffany, and Linda are African-American women in their 40's and all have earned or are working towards graduate degrees. The social/racial/economic intersection within this subset of the participants is telling and goes beyond the scope of this study. However, it is worth mentioning and warrants further investigation.

The above-mentioned narratives indicate the optimistic and adverse results from graduating from an FPCU. Most of the participants claimed to have experienced positive outcomes and these participants stated that they would recommend their institution and specified their level of satisfaction. Even participants who have yet to achieve professional advancement indicated feelings of satisfaction. This notion of satisfaction post-graduation or while enrolled is present within the participant narratives. It speaks against what some may assume about the for-profit industry and what is reported in the media. However, it is unclear if the study participants were aware of the stigma 
associated with FPCUs and if so to what extent did that influence their experience or perception.

There is a significant lack of literature surrounding the for-profit college student experience, much less the graduated student perspective. The research on the FPCU sector excludes the student narrative and focuses on the growth of for-profit institutions and the financial aid policies that greatly assisted in the prevalence of the sector. Much of what is discussed in the literature in terms of the for-profit student center on student choice. The results of this study contribute to the discussion of FPCU student choice from the graduate perspective. Nevertheless, with this information subsequent studies may support these findings or conclude otherwise; however, these findings provide a foundation to continue the research on the for-profit industry at large.

\section{Financial Aid and Cost}

The research participants indicated that financial aid and cost factors of attending an FPCU is a sub-component of their post-graduation experience. The financial perspective of the present study supplements the answered research questions. However, the findings suggest that financial aid and cost of attendance was not a substantial element of the pre-enrollment process nor did it affect the student experience. Two participants, Kate and Sara, utilized employee tuition benefits to cover tuition expenses. Helen, the international student, paid her tuition in full without financial assistance because she is wealthy. In these three instances, federal financial aid was not utilized or needed. In contrast, for the remaining participants who required financial aid, this element was repeatedly included in their post-graduate experience. The literature indicates that financial aid is a significant component of FPCU choice. Cellini's (2010) 
research concluded that federal aid programs encourages FPCU enrollment, which is congruent with nine out of 12 participants requiring federal financial assistance.

\section{Recommendations for Future Research}

In order to remain objective, I decided not to ask the research participants about the controversial aspects surrounding the for-profit colleges and universities. I felt that the research respondents would not be as open in discussing their experiences if I mentioned the contentious facets of the for-profit college industry. In retrospect, I now would like to have discussed the stigma associated with FPCUs. A few participants demonstrated awareness of the negative issues for-profits face but did not go into detail. However, I did not explore deeper to maintain neutrality and avoid disrupting the participant perspective and alter their willingness to participate in the present study. The exploration into the awareness of the for-profit industry may have provided further reflection and would have expanded the participant narratives. Were the participants aware of the pitfalls FPCUs face and how this fact did not influence their decisions? Were they even aware that their school was a for-profit college? These questions should be included in future studies on for-profit college students and graduates to offer expanded exploration into the student experience.

Limiting the study to South Florida significantly affected the findings of this study. The geographical restriction was too narrow and irrelevant to the larger context of for-profit education. Most of the participants graduated from institutions that conduct their programs fully online from large national chains (i.e., University of Phoenix). Without the geographical limitation, the study would have garnered a larger and more diverse sample, which may have led to generalizable findings. The geographical 
restriction would have been applicable and appropriate if smaller and local FPCUs were represented in this study. Therefore, the geographical limitation was irrelevant to this study. A nationwide sample is well suited for future FPCU student research.

In addition to expanding the sample nationwide and further exploring the associated stigma around FPCUs, a focus group, conducted after interviews, could have provided additional narratives and insight into the FPCU student experience. A potential outcome from focus groups include shared experiences not otherwise found within the personal narratives in an interview setting. Consequently, I suggest that future qualitative research addressing the FPCU graduate experience should include focus groups, if applicable.

The socioeconomic status of the research participants was not thoroughly explored within this study. An examination of the socioeconomic and cultural aspect of this study, especially with respect to race and gender, could have provided a deeper background and impact of the pre and post-graduation experiences of FPCU students. Most of the participants indicated the need for financial aid. Some participants were vocal in their frustration regarding their student loan repayment status in comparison to their compensation. However, future studies should incorporate an extensive examination of the socioeconomic component of FPCU students.

\section{FPCU Research Implications}

The implications of this study contribute to the research of for-profit colleges and universities as a whole. The participant narratives provide context into the FPCU student/graduate experience from the pre-enrollment phase throughout graduation. As a result of the present study, participants provided insight and supported the rationale for 
how and why they chose to attend an FPCU. The student experience aspect confirmed that they rely on professor and institutional support throughout their enrollment. Participants did not value or utilize extracurricular activities and support services outside of their advisor and instructor. The participants largely indicated positive feedback and degree satisfaction. Although not immediate, the participants achieved post-graduation career advancement. For others who may not have obtained career prospects, they still maintained a positive perspective on their experience.

Are the results of this research surprising? To some extent, yes. However, the present study's participants represent a small portion of approximately the $25 \%$ of students who graduate from a for-profit college within six years. Can we assume that our biased knowledge of the industry speaks to the other $75 \%$ that do not persist? Perhaps this research intends to amplify the voices of those that have succeeded within a notorious setting. Contrastingly, the present research implies the need to consider why FPCUs have such poor graduation rates. Alternatively, perhaps the lens in which the forprofit industry is viewed is that of the dominant traditional higher education perspective.

The current research also confirms the literature with respect to the FPCU enrollment demographics. According to Boykin (2017) the average FPCU student is a minority female aged 27 . She is married with children and maintains full-time or parttime employment while enrolled. The study's participants are mostly minority women and are married with children. As previously indicated, a majority of the study's participants achieved a promotion or career advancement. However, three AfricanAmerican women did not, although they expressed positive sentiments from their 
experience. The reasons for this outcome vary, but it is interesting to note and could be further explored from the socio-cultural and economic perspective.

Higher education scholars should consider and explore the ramifications of an FPCU degree. It is not enough to examine the for-profit industry from a macro-level perspective. A challenge in this research study is how the rapidly changing FPCU environment was affected. In writing the present study, some institutions closed or changed ownership. Delayed federal policy and high-profile settlements influenced (and often confused) the direction of this research study. Throughout the course of this research, vast shifts towards FPCU regulations occurred, mainly because of the presidential election. In other words, it was difficult to keep up with the occurring changes. Nevertheless, the implications of this research contribute to the base of the forprofit industry, namely their students.

For-profit students require extensive exploration to provide deeper and rich context of the for-profit industry. The FPCU student insight serves as a foundation to investigate further and produce more knowledge of the sector. Further, the obtained information can be used to educate those considering an FPCU or those interested in the for-profit sector. The participants did not discuss, nor were asked, about how for-profit institutions differ from traditional non-profit institutions; answering the questions on the difference between for-profit and non-profit schools could have provided additional detail of the FPCU student perspective.

The findings of this research suggest that the traditional non-profit sector could provide educational opportunities to students like the study's participants. Apparently, participants sought, and in some cases attended, non-profit institutions (public or private). 
However, participants indicated that service, level of care, and consideration was absent at the non-profit school and the institutional environment did not suit them well. Other participants mentioned that they were not admitted to a non-profit due to academic performance and preparedness. The participant narratives also indicated that traditional schools were not considered in the pre-enrollment process and the convenience and flexibility component contributed to the student choice factor.

The for-profit industry has dominated the online and distance learning segment of higher education at the University of Phoenix. However, several public and private notfor-profit colleges have ramped up their online education units and, in some cases, have partnered with for-profit education providers. In 2018, Purdue University acquired Kaplan University. The acquisition resulted in Purdue University Global, the online education arm of Purdue University (Fain, 2018). In 2019, Arizona State University announced plans to establish a for-profit project that leverages company partnerships to boost enrollment into ASU online programs (Blumenstyk, 2019). It will be interesting to observe the for-profit industry, as the traditional sector of higher education replicate large online units and business models.

In summary, the implications of the present research study center on the graduate experience, from the pre-enrollment stage throughout post-graduation. A significant component of the study addresses FPCU choice. The findings of this research imply that students self-select into an FPCU for various reasoning. Their reasoning ranges from cost factors, convenience, and flexibility. Their student experience could be characterized as atypical and transactional. The post-graduation data reveal positive indicators and overall 
degree satisfaction. I discuss the recommendations of this research and include areas to strengthen this study and future research on FPCU graduates.

\section{Limitations}

The limitations of this study are apparent in that it does not contain a comprehensive scope of FPCU student choice in higher education. There are reputable and accredited for-profit colleges, career, and vocational institutions that provide students with a quality education. However, the present study focuses on the South Florida forprofit market where there is controversy involving FPCUs that allegedly practice predatory recruiting behaviors. For example, ATI Career Training center shutdown amidst fraud allegations in 2013 and in 2016 Dade Medical College closed abruptly due to financial issues.

The sample of research participants is small and is contained to one geographic region (South Florida). However, considering that the South Florida region offers 11 regionally accredited institutions, students have several options to consider. Therefore, the research questions and the study aim to answer only a portion of the research problem, which is that if students have choices and sometimes there are more affordable options, why are they choosing to attend a for-profit college and how have the students fared upon completing a program at an FPCU.

\section{Concluding Thoughts}

Despite the research and discourse of for-profit higher education, students continue to self-select and enroll into these institutions. The for-profit college sector has absorbed continued notoriety and persists in today's higher education market. The present research study provides a component central to the FPCU sector, the students. The FPCU 
graduate perspective is absent from the research and literature. This perspective is critical to understanding why FPCUs are so successful. The findings may imply that traditional institutions can replicate the for-profit model to enroll and service this population through online education and distance learning partnerships and have begun to do so. For example, Purdue University's purchase of Kaplan University demonstrates the necessity for traditional non-profit colleges and universities to leverage for-profit proficiencies in the online education market. Collaboration between the for-profit and non-profit higher education sectors may lead to continued innovation while servicing a student population intent on obtaining a degree without compromising their employment status, parental obligations, and other relevant factors.

FPCUs serve a population that, for many reasons, were not applicable to the respondents of this study. Reasons to attend an FPCU included poor prior academic performance at a traditional college, the need for technology/distance learning options, and convenience and cost factors. Participants indicated that they had a positive experience, even with the notoriety of certain FPCUs. They mostly elected to attend a for-profit college to increase employment and career outlooks. The participants reported to have achieved some success in their professional growth.

These findings do not necessarily contradict what we know about for-profits because the usual population refers to individuals who are not graduates. Therefore, the findings indicate the need for further examination of FPCU graduates and their perceived outcomes on a larger scale.

The represented participants identified as minorities, African-American and Hispanic, which confirms the FPCU enrollment data. From a socio-cultural and economic context, 
the racial significance warrants further examination of how traditional universities neglect this demographic who are intent on obtaining a post-secondary credential.

The financial aid component of for-profit higher education research indicates that the cost of attendance is expensive and the dependence on financial aid for FPCU students is substantial. The research participants specified the severity of their student loans but affirm that it was necessary for them to persist and ultimately graduate. From the participant narratives' perspective, student loans were unavoidable.

The narratives demonstrated that students self-select into for-profit colleges and creative advertising did not influence their decision. This is in stark contrast with recent allegations of fraud and misrepresentation of career outlooks on behalf of certain forprofit colleges (i.e. University of Phoenix). It is clear that participants' career goals played a factor in their decisions, but the participants' information in terms of their career trajectories did not develop from the institution they attended, but rather from their own perceptions.

The answered research questions provide rich context to the field of higher education study and sheds a positive light on the FPCU graduate experience. Yet, this study included an analysis of large national chain schools, such as DeVry University. An examination of smaller colleges could provide and reflect some of the conducted literature of for-profit colleges and universities.

Personally, this study helped me to recognize that the default higher education lens is that of the non-profit/traditional view. Students who attend FPCUs do not maintain such perspective and consider how the degree will assist them to reach their primary career objective. The degree satisfaction component of this study was surprising and in 
some cases heartwarming. The look and sounds of happiness when participants would express their feelings of graduation were vivid. If the graduates were able to secure employment opportunities and were happy with the outcome of their degree, then perhaps for-profit education is worthwhile and valid. Still, graduation from the for-profit sector remains at $25 \%$. Perhaps it is feasible to consider if graduation rates increase and degree satisfaction is present, the discourse and literature may alter as well.

In summary, this research study on for-profit colleges and university demonstrates the need for additional exploration of the FPCU student experience. The participants recounted their overall positive sentiment of their experience and most achieved career advancement. The socioeconomic status of FPCU students intersect with racial considerations and the student loan component. Further research is required on a national scale to explore these intersections and comprehend the FPCU graduate experience, including outcomes. 


\section{REFERENCES}

Alase, A. (2017). The Interpretative Phenomenological Analysis (IPA): A Guide to a Good Qualitative Research Approach. International Journal of Education and Literacy Studies, 5(2), 9-19.

Altman, G. (01/15/2016). DoD reinstates University of Phoenix for military tuition assistance. Retrieved from https://rebootcamp.militarytimes.com/educationtransition/2016/01/15/dod-reinstates-university-of-phoenix-for-military-tuitionassistance/.

Arbeit, C. A., \& Horn, L. (2017). A profile of the enrollment patterns and demographic characteristics of undergraduates at for-profit institutions. Stats in brief. NCES 2017416. National Center for Education Statistics. , P.O. Box 1398, Jessup, MD 20794-1398. Retrieved from http://ezproxy.fiu.edu/login?url=https://search-proquestcom.ezproxy.fiu.edu/docview/1895981327?accountid=10901.

Bartlett, T. (2009) Phoenix risen: How a history professor became the pioneer of the forprofit revolution. The Chronicle of Higher Education.

https://www.chronicle.com/article/Phoenix-Risen/46988.

Baum, S., Kurose, C., \& McPherson, M. (2013). An overview of American higher education. Future of Children, 23(1), 17-39. https://doi.org/10.1353/foc.2013.0008

Belfield, C. R. (2013). Student loans and repayment rates: The role of for-profit colleges. Research in Higher Education, 54(1), 1-29.

Berg, G. A. (2005). Lessons from the edge: for-profit and nontraditional higher education in America. Praeger.

Benites, M. A. (2015). An interpretative phenomenological analysis of academically resilient Hispanic graduate and post-graduate students (Order No. 3703503). Available from ProQuest Dissertations \& Theses Global. (1689439956).

http://access.library.miami.edu/login?url=https://search.proquest.com/docview/16894399 56 ? accountid $=14585$

Bennett, D. L., Lucchesi, A. R., \& Vedder, R. K. (2010). For-Profit higher education growth, innovation and regulation acknowledgements.

https://files.eric.ed.gov/fulltext/ED536282.pdf

Blumenstyk, G. (2012) For-profit colleges compute their own graduation rates. The Chronicle of Higher Education. https://www.chronicle.com/article/For- ProfitsDevelop/131048 
Blumenstyk, G. (2019) Arizona State will create a for-profit spinoff to court students in the work force. Chronicle of Higher Education.

https://www.chronicle.com/article/Arizona-State-Will-Create-a/245929

Bogdan, R. C. \& S.K. Biklen (2007). Foundations of qualitative research for education. InQualitative research for education: An Introduction to theory and methods (5th ed.), (24-81). Pearson.

Boykin, T. F. (2017). For profit, for success, for black men: A review of literature on urban for-profit colleges and universities. Urban Education, 52(9), 1140-1162. https://doi.org/10.1177/0042085915618724

Brocki, J. M., \& Wearden, A. J. (2006). A critical evaluation of the use of interpretative phenomenological analysis (IPA) in health psychology. Psychology \& Health, 21(1), 87108. http://dx.doi.org.ezproxy.fiu.edu/10.1080/14768320500230185

Cellini, S. R. (2010). Financial aid and for-profit colleges: Does aid encourage entry? Journal of Policy Analysis and Management,29(3), 526-552.

Cellini, S. R., \& Chaudhary, L. (2014). The labor market returns to a for-profit college education. Economics of Education Review, 43, 125-140.

https://doi.org/10.1016/j.econedurev.2014.10.001

Chappell, B. (2019, December 10) University of Phoenix reaches \$191 million settlement with FTC, including debt relief. https://penandthepad.com/cite-npr-apa-8568887.html

Chung, A. (2008). MPRA: The effects of for-profit college training on earnings effects of for profit college training on earnings. http://mpra.ub.uni-muenchen.de/18972/

Chung, A. S. (2012). Choice of for-profit college. Economics of Education Review, 31(6), 1084-1101. https://doi.org/10.1016/j.econedurev.2012.07.004

Cottom, T. M. (2017). Lower ed: The troubling rise of for-profit colleges in the new economy. The New Press.

Creswell, J. W., Hanson, W. E., Clark Plano, V. L., \& Morales, A. (2007). Qualitative research designs: Selection and implementation. The counseling psychologist, 35(2), 236264.

Darolia, R., Koedel, C., Martorell, P., Wilson, K., \& Perez-Arce, F. (2015). Do employers prefer workers who attend for-profit colleges? Evidence from a field experiment. Journal of Policy Analysis and Management, 34(4), 881-903. http://ezproxy.fiu.edu/login?url=https://search-proquestcom.ezproxy.fiu.edu/docview/1773223924?accountid=10901 
DataUSA. (2019). American Intercontinental University.

[Chart].https://datausa.io/profile/university/american-intercontinental-university-online

DataUSA. (2019). DeVry University - Illinois. [Chart].

https://datausa.io/profile/university/devry-university-illinois\#enrollment

DataUSA. (2019). Strayer University - Georgia. [Chart].

https://datausa.io/profile/university/strayer-university-georgia

Deming, D., Goldin, C., \& Katz, L. (2013). For-profit colleges. Future of

Children, 23(1), 137-163.

Deming, D. J., Yuchtman, N., Abulafi, A., Goldin, C., Katz, L. F., Chi, O., Zhou, W. (2016). The Value of Postsecondary Credentials in the Labor Market: An Experimental Study. American Economic Review, 106(3), 778-806.

https://doi.org/10.1257/aer.20141757

Denice, P. (2015). Does it pay to attend a for-profit college? Vertical and horizontal stratification in higher education. Social Science Research, 52, 161-178

https://doi.org/10.1016/j.ssresearch.2015.02.002

Douglas- Gabriel, D. (2015, October 9). Why the Defense Department is kicking the University of Phoenix off military bases. https://www.washingtonpost.com/news/gradepoint/wp/2015/10/09/why-the-defense-department-is-kicking-the-university-of-phoenixoff-military-bases/

Douglass, J. A. (2012). The rise of the for-profit sector in US higher education and the Brazilian effect. European Journal of Education, 47(2), 242-259.

Fain, P. (2018, March 6) Accreditor backs Purdue-Kaplan Deal. Inside Highered. https://www.insidehighered.com/quicktakes/2018/03/06/accreditor-backs-purdue-kaplan deal

Floyd, C. E. (2007). Know your competitor: Impact of for-profit colleges on the higher education landscape. New Directions for Higher Education, 2007(140), 121-129. https:// doi: $10.1002 /$ he. 286

Garrity, B. K., Garrison, M. J., \& Fiedler, R. C. (2010). Access for whom, access to what? The role of the "disadvantaged student" market in the rise of for-profit higher education in the united states. Journal for Critical Education Policy Studies, 8(1), 202244.

Gilpin, G. A., Saunders, J., \& Stoddard, C. (2015). Why has for-profit colleges' share of higher education expanded so rapidly? Estimating the responsiveness to labor market changes. Economics of Education Review, 45, 53-63.

https://doi.org/10.1016/j.econedurev.2014.11.004 
Grubb, W. N., \& Lazerson, M. (2004). The education gospel: The economic power of schooling. Harvard University Press.

Hassler, R. P. (2006). The flogging of for-profit colleges. Academic Questions, 19(3), 63-74. https://doi.org/10.1007/s12129-006-1005-9.

Heller, D. E. (2011). The impact of gainful employment regulations. Change: The Magazine of Higher Learning, 43(5), 58-64.

Howard-Vital, M. (2006). The appeal of for-profit institutions. Change: The Magazine of Higher Learning, 38(1), 68-71.

Iloh, C. (2016). Exploring the For-Profit Experience. American Educational Research Journal,53(3), 427-455. https://doi:10.3102/0002831216637338

Iloh, C., \& Tierney, W. G. (2014). Understanding for-profit college and community college choice through rational choice. Teachers College Record, 116(8). http://ezproxy.fiu.edu/login?url=https://search-proquest com.ezproxy.fiu.edu/docview/1651856432?accountid=10901

Johnson, M. R. (2017). Understanding college students' civic identity development: A grounded theory. Journal of Higher Education Outreach and Engagement, 21(3), 31-59. Retrieved from http://ezproxy.fiu.edu/login?url=https://search-proquestcom.ezproxy.fiu.edu/docview/1969013430?accountid=10901

Katzman, J. (2016). The spending war on student recruitment. Inside Higher Ed. https://www.insidehighered.com/views/2016/04/18/too-much-being-spent-highereducation-marketing-assault-essay

Kurantowicz, E., \& Nizinska, A. (2013). How students "stay the course": Retention practices in higher education. Studies in the Education of Adults, 45(2), 135-147. Retrieved from http://ezproxy.fiu.edu/login?url=https://search-proquestcom.ezproxy.fiu.edu/docview/1651851303?accountid=10901

Kinser, K. (2006). From main street to wall street: The transformation of for-profit education. (ASHE Higher Education Report Vol. 31, No. 5). Jossey Bass.

Kinser, K. (2007). Dimensions of corporate ownership in for-profit higher education. Review of Higher Education, 30(3), 217-245.

Kreighbaum, A. (2017, January 4) ITT Students Seek Recognition in Bankruptcy Lawsuit. Inside Higher Ed. https://www.insidehighered.com/quicktakes/2017/01/04/ittstudents-seek-recognition-bankruptcy-lawsuit 
Kreighbaum, A. (2019, April 3) Few Lessons Learned on For-Profit Closures. Inside Higher Ed. https://www.insidehighered.com/news/2019/04/03/another-profit-giantcollapses-critics-dream-center-deal-wonder-why-feds-didnt-seek

Kreighbaum, A. (2019, May 28) Turning to Courts for Loan Forgiveness. Insider Higher $E d$. https://www.insidehighered.com/news/2019/05/28/some-defrauded-borrowers-wincourt-debt-relief-claims-pile

Kreighbaum, A. (2019, September 26) Student Loan Default Rate Continues to Decline. Inside Higher Ed. https://www.insidehighered.com/quicktakes/2019/09/26/student-loandefault-rate-continues-decline

Larkin, M. \& Thompson, A. (2012) Interpretative phenomenological analysis. In A. Thompson \& D. Harper (Eds.), Qualitative research methods in mental health and psychotherapy: A guide for students and practitioners (pp. 99-116). John Wiley \& Sons.

Lederman, D. (2019, March 14) Career Education Corp. buys online university. Insider Higher Ed. https://www.insidehighered.com/quicktakes/2019/03/14/career-education corp-buys-online university

Lincoln, Y. S., \& Guba, E. G. (1985). Naturalistic inquiry. Sage Publications. http://search.ebscohost.com.ezproxy.fiu.edu/login.aspx?direct=true\&db=cat06026a\&AN $=$ fiu. $020112641 \&$ site $=$ eds-live

Lynch, M., Engle, J., \& Cruz, J. L. (2011). Lifting the fog on inequitable financial aid policies: A companion brief to "priced out": How the wrong financial aid policies hurt low-income students. Education Trust. http://ezproxy.fiu.edu/login?url=https://searchproquest-com.ezproxy.fiu.edu/docview/964190755?accountid=10901

Ma, J., Baum, S., Pender, M., \& Welch, M. (2016). Trends in college pricing, 2016. trends in higher education series. College Board. http://ezproxy.fiu.edu/login?url=https://search-proquest com.ezproxy.fiu.edu/docview/1895970639?accountid=10901

Marcus, J. (2019). Can for-profit colleges rebound? A second chance to innovate, amid tough market conditions. Education Next 19(1). https://search.proquest.com/openview/de05af63a38fc437c702e4f5003c738e/1?cbl=20501 54\&pq-origsite $=$ gscholar

Marshall, C. \& Rossman, G. (2011). Designing Qualitative Research: $5^{\text {th }}$ Edition. Sage.

Merriam, S. B. (2002). Qualitative research in practice: examples for discussion and analysis. Jossey-Bass 
Macqueen, G. (2012). Closing doors: The gainful employment rule as over-regulation of for-profit higher education that will restrict access to higher education for America's poor. Georgetown Journal on Poverty Law and Policy, 19(309).

McKoy, K. (2018, May 27) Student loans: Former Corinthian Colleges students win a reprieve in fight with feds. USA Today.

https://www.usatoday.com/story/money/2018/05/27/corinthian-students-get-partialstudent-loan-win-court-fight/647782002/

McKenzie, L. (2018, April 23). The 100K Club. Inside Higher Ed. https:/www.insidehighered.com/news/2018/04/23/nonprofits-poised-unseat-u-phoenixlargest-online-university

Mettler, S. (2014). Degrees of inequality: How the politics of higher education sabotaged the American dream. Basic Books.

Murphy, C. G., \& Hicks, T. (2006). Academic characteristics among first-generation and non-first-generation college students. College Quarterly, 9(2), 1-20. Retrieved from http://ezproxy.fiu.edu/login?url=https://search-proquest com.ezproxy.fiu.edu/docview/61870482?accountid=10901

National Center for Educational Statistics. (2018). [Table 317.40]

https://nces.ed.gov/programs/digest/d18/tables/dt18_317.40.asp

National Center for Educational Statistics. (2020). Fast facts: Graduation rates. Retrieved May 2, 2020, from https://nces.ed.gov/fastfacts/display.asp?id=40

Oreopoulos, P., \& Petronijevic, U. (2013). Making college worth it: A review of the returns to higher education. Future of Children, 23(1), 41-65. http://ezproxy.fiu.edu/login?url=https://search-proquestcom.ezproxy.fiu.edu/docview/1509088456?accountid=10901

Oseguera, L., \& Malagon, M. C. (2011). For-profit colleges and universities and the Latina/o students who enroll in them. Journal of Hispanic Higher Education, 10(1), 6691.

Perna, L.W. (2006) Studying college access and choice: A proposed conceptual model. In J. C. Smart (Ed.). Higher Education: Handbook of Theory and Research, vol. 21. Springer, Dordrecht.

Rodham, K., Fox, F., \& Doran, N. (2015). Exploring analytical trustworthiness and the process of reaching consensus in interpretative phenomenological analysis: Lost in transcription. International Journal of Social Research Methodology, 18(1), 59-71. 
Rodriguez, B. A. (2014). Education for all or profit for few? Analyzing the behavior of college-going students attending for-profit colleges. Metropolitan Universities, 25(1), 147-164. http://files.eric.ed.gov/fulltext/EJ1092793.pdf

Saul, S. (2015, November 16) For-profit college operator EDMC will forgive student loans. The New York Times. https://www.nytimes.com/2015/11/17/us/for-profit-college operator-edmc-will forgive-student-loans.html

Schilling, J. (2013). What's money got to do with it? The appeal of the for-profit education model. Community College Journal of Research and Practice, 37(3), 153-159.

Sheldon, C. Q. (2009). Predictors of transfer to 4-year, for-profit institutions. Community College Review, 37(1), 34-51.

Smith, A. (2017, December 6) Handing off DeVry. Inside Higher Ed. https://www.insidehighered.com/news/2017/12/06/devry-traded-private-small-company

Smith, A. (2018, March 27). Bucking the Trend. Inside Higher Ed. https://www.insidehighered.com/news/2018/03/27/strayer-expands-while-most-bigprofits-keep-shrinking

Smith, A. (2019, January 24). Former EDMC campuses bought by private investors. Inside Higher Ed. https://www.insidehighered.com/news/2019/01/24/private-investmentfirm-behind-acquisition-art-institutes-and-south-university

Smith, J. A. (2011). Evaluating the contribution of interpretative phenomenological analysis. Health psychology review, 5(1), 9-27.

Smith, J. A., Flowers, P. \& Larkin, M. (2009). Interpretative phenomenological analysis: Theory, methods and research. Sage Publications.

Smith, J. A., Flowers, P., \& Osborn, M. (1997). Interpretative phenomenological analysis and the psychology of health and illness. Material discourses of health and illness, 68-91.

Stewart, I. (2019, January 3). Nearly 180,000 students won't have to repay loans from for-profit higher ed company. NPR. https://www.npr.org/2019/01/03/682057881/nearly180-000-students-wont-have-to-repay-loans-from-for-profit-higher-ed-compa

Stratford, M. (2015, April 15) Corinthian dismantling continues. Inside Higher Ed. https:/www.insidehighered.com/news/2015/04/15/us-fines-corinthian-colleges-30million-and-effectively-closes-heald-chain

Stratford, M. (2017). Trump and DeVos fuel a for-profit college comeback: Scrutiny of fraud fades as feds go lax on an industry that Obama targeted. https://www.politico.com/story/2017/08/31/devos-trump-forprofit-college-education242193 
Swenson, C., Warren, D., \& Boggs, G. (2005). Point/counterpoint: For-profit institutions in the higher education reauthorization. Change, 37(3), 20.

Thomason, A. (2015, July 9). Accreditor takes U. of Phoenix off notice 2 years after concerns were raised. https://www.chronicle.com/blogs/ticker/accreditor-takes-u-ofphoenix-off-notice-2-years-after-concerns-were-raised/101733

The Institute for College Access \& Success. (2019). Quick Facts about Student Debt. http://bit.ly/11xjskr.

Tierney, W. G. (2011). Too big to fail: The role of for-profit colleges and universities in American higher education. Change: The Magazine of Higher Learning, 43(6), 27-32.

Whitford, E. (2018, July 11). Strayer and Capella Merger Approved. Inside Higher Ed. https://www.insidehighered.com/quicktakes/2018/07/11/strayer-and-capella-merger approved

Yeoman, B. (2011). The high price of for-profit colleges. Academe, 97(3), 32-37. 
Appendix A: Screening Questionnaire

\section{FOR-PROFIT COLLEGE AND UNIVERSITY \\ PARTICIPANT SCREENING QUESTIONNAIRE}

1. Please identify your educational credentials? Circle all that apply

High School Diploma

Associates of Arts (AA)

Bachelor's degree (BA, BS)

Master's degree (MA, MSc, MSed)

Post-masters or terminal degree (PhD, EdD, PSyD)

1A. If you have obtained a Bachelor's degree or higher, please specify the degree, the major, the institution where the degree was obtained, and the year the degree was obtained below: \{Ex. Bachelor of Arts in Business, marketing major, Florida Int'l University, 2005\}

2. Please list all colleges or universities attended and the location: (i.e. Florida Int'l University, Miami, FL)

3. Have you attended any of the colleges listed below, if so, please identify:

DeVry University

Kaplan University

Everglades University

Everest University

Miami Regional University

College of Business Technology

South University

Miami International University

of Art \& Design
Florida National University

The Art Institute of Ft.

Lauderdale

The Art Institute of Miami

Florida Career College

Florida Technical College

4. Have you ever or never considered attending a for-profit college or university? If so, please indicate what college and why? 
Appendix B: Interview \& Focus Group Schedule (Iloh \& Tierney, 2014)

Teachers College Recond, 116, 080304 (2014)

\section{APPENDIX A}

Survey Questions

1. Please fill in or circle in the corresponding identity information:

a. Age:

b. Marital status (Circle that which applies): Single Married

c. Do you have any children? __ If so, how many?

d. What is your annual household income?

e. Race? (Circle that which applies):

- White

- African American

- Hispanic

- Asian Pacific Islander

- Native American

- Other

f. Gender? (Circle that which applies): Male Female

2. What program are you enrolled in at your college?

3. How did you first hear about this school/program?

4. Did you look into any other schools or programs before enrolling in your program? If so, which one(s)?

5. What made you consider this school? (e.g., program/curriculum, schedule, financial aid, location, prestige/reputation, length of program, homework load)

6. Did you speak to anyone at the school before deciding to enroll?

7. How did you communicate with school representatives? (e.g., by phone, in-person, email)

8. What did the school representative discuss with you?

9. What are the total costs for the program?

10. Before enrolling in the program, were you aware of the cost of the program? (tuition, books, fees, etc.)

11. Did you compare these costs with that of other programs and colleges?

12. Did anyone speak to you about financial aid before enrolling?

13. Before enrolling, were you aware of the following (circle the letters for everything you were aware of):

a. The average financial aid package awarded to students in the program?

b. The breakdown of loans versus grant awarded by the program? 
Appendix B: Interview \& Focus Group Schedule (Iloh \& Tierney, 2014)

TCR, 116, 080304 Understanding College Choice Through Rational Choice

c. The percentage of students who receive college grants?

d. The average college debt for students?

e. The degree completion rate for the program?

14. What, if any, do you think are the differences between community college and for-profit college and the student body?

15. (Please circle and respond) I feel that students at community college/ for-profit college are more/ (or) /less like me. Why?

16. Did anyone at your school speak to you about job opportunities after graduation?

17. Did they tell you what percentage of students in your program find jobs after graduation?

18. Did anyone at your school speak to you about the average starting salary for students who graduate from your program?

19. How much do you expect to earn per hour/per month when you graduate?

20. (Please circle your answer) If you took out loans, are they:

a. less than $\$ 1,000$;

b. $\$ 1,001-\$ 3,000$;

c. $\$ 3,001-\$ 5,000$;

d. $\$ 5,001-\$ 7,000$;

e. $\$ 7,001-\$ 9,000$

f. More than $\$ 9,000$ 
Appendix B: Interview \& Focus Group Schedule (Iloh \& Tierney, 2014)

Teachers College Record, 116, 080304 (2014)

\section{APPENDIX B}

Focus Group \& Interview Questions

1. Describe to me the process leading up to your decision to attend this institution.

2. What would you say were some of the most important factors in choosing to attend this institution? Were there other institutions you considered?

3. Before enrolling in the program, were you aware of the cost of the program (tuition, books, fees, etc.)? What is your perception of the cost?

4. How are you planning on paying for the costs of the program?

5. Do you enjoy anything about this program/institution? If so, please share.

6. Is there anything that needs improvement at this institution? Please share further if so.

7. What were your initial expectations prior to attending this institution?

8. Is your current experience consistent with your initial expectations coming here? Please elaborate further.

9. What are you looking forward to or expecting after graduating?

10. Is there anything else you would like to share? Do you have any questions for me? 
Appendix C: FPCU Graduate - Interview Schedule

1. Please describe your college recruiting and selection process.

2. What factors, circumstances, interests, made you consider this school?

3. Please describe your thought process and what factors you considered when you made your decision?

4. Please explain the financial aid process, whether you received federal financial aid, self-supported or if your tuition expenses were paid through other means.

5. What feelings did you experience when you enrolled at your FPCU

6. Please describe the enrollment and registration process at your FPCU.

7. Please describe your experience while enrolled at an FPCU? What you liked/didn't like?

8. Please describe the most memorable courses/instructors.

9. What areas did your FPCU excel in, while you were enrolled and why?

10. What areas could your FPCU improve on, while you were enrolled and why?

11. Please describe the facilities where classes were held?

12. Please describe how technology was used in your program?

13. If your program was fully online, please describe how your instructors and technology played a role in your courses.

14. If your program was fully online, please describe your online experience.

15. What student services were provided (Library, Help Desk, Bookstore, etc.)?

16. What career expectations did you have prior to enrolling at your FPCU?

17. What career expectations did you have while you were enrolled at your FPCU?

18. Describe your employment status, pre-student, while a student and postgraduation?

19. Please explain how earning a degree affected your career?

20 . What career related experiences did you encounter upon completing your degree?

21. How would you describe your FPCU student experience, from recruiting/decision making process through post-completion?

22. What do you think about your FPCU? 


\section{Appendix D: Participant Summary Table}

Table 1

Participant Summary Table

\begin{tabular}{|c|c|c|c|c|c|c|}
\hline Participant & $\begin{array}{l}\text { Age } \\
\text { Range }\end{array}$ & Gender & Race/Ethnicity & $\begin{array}{l}\text { Degree } \\
\text { Level }\end{array}$ & Year & FPCU \\
\hline Kate & $\begin{array}{l}35- \\
40\end{array}$ & Female & White/Hispanic & $\begin{array}{l}\text { Associate } \\
\text { Bachelors }\end{array}$ & $\begin{array}{l}2009 \\
2014\end{array}$ & $\begin{array}{l}\text { Brown Mackie College } \\
\text { Argosy University }\end{array}$ \\
\hline Sara & $\begin{array}{l}30- \\
35\end{array}$ & Female & White/Hispanic & Bachelors & 2014 & DeVry University \\
\hline Tiffany & $\begin{array}{l}35- \\
40\end{array}$ & Female & $\begin{array}{l}\text { Black/African- } \\
\text { American }\end{array}$ & $\begin{array}{l}\text { Associate } \\
\text { Bachelors }\end{array}$ & $\begin{array}{l}2017 \\
2018\end{array}$ & $\begin{array}{l}\text { University of Phoenix } \\
\text { University of Phoenix }\end{array}$ \\
\hline Linda & $\begin{array}{l}40- \\
45\end{array}$ & Female & $\begin{array}{l}\text { Black/African- } \\
\text { American }\end{array}$ & Masters & 2009 & University of Phoenix \\
\hline Nicole & $\begin{array}{l}35- \\
40\end{array}$ & Female & White/Hispanic & Bachelors & 2014 & University of Phoenix \\
\hline Michael & $\begin{array}{l}35- \\
40\end{array}$ & Male & $\begin{array}{l}\text { Black/African- } \\
\text { American }\end{array}$ & Masters & 2012 & Strayer University \\
\hline Diane & $\begin{array}{l}45- \\
50\end{array}$ & Female & $\begin{array}{l}\text { Black/African- } \\
\text { American }\end{array}$ & Masters & 2011 & Strayer University \\
\hline Helen & $\begin{array}{l}55- \\
60 \\
\end{array}$ & Female & White/Hispanic & Bachelors & 2016 & $\begin{array}{l}\text { The Art Institute of } \\
\text { Miami }\end{array}$ \\
\hline Amy & $\begin{array}{l}40- \\
45\end{array}$ & Female & $\begin{array}{l}\text { Black/African- } \\
\text { American }\end{array}$ & $\begin{array}{l}\text { Associate } \\
\text { Bachelors }\end{array}$ & $\begin{array}{l}2013 \\
2016\end{array}$ & $\begin{array}{l}\text { University of Phoenix } \\
\text { University of Phoenix }\end{array}$ \\
\hline Victoria & $\begin{array}{l}40- \\
45\end{array}$ & Female & Black/Hispanic & Masters & 2010 & DeVry University \\
\hline Rachel & $\begin{array}{l}35- \\
40\end{array}$ & Female & $\begin{array}{l}\text { Black/African- } \\
\text { American }\end{array}$ & $\begin{array}{l}\text { Associate } \\
\text { Bachelors } \\
\text { Masters }\end{array}$ & $\begin{array}{l}2012 \\
2012 \\
2017\end{array}$ & $\begin{array}{l}\text { American Intercontinental } \\
\text { University } \\
\text { American Intercontinental } \\
\text { University } \\
\text { Everest University }\end{array}$ \\
\hline Kim & $\begin{array}{l}30- \\
35\end{array}$ & Female & $\begin{array}{l}\text { Black/African- } \\
\text { American }\end{array}$ & $\begin{array}{l}\text { Associate } \\
\text { Bachelors }\end{array}$ & $\begin{array}{l}2010 \\
2013\end{array}$ & $\begin{array}{l}\text { Brown Mackie College } \\
\text { DeVry University }\end{array}$ \\
\hline
\end{tabular}




\section{Appendix E: FPCU Degree Summary Table}

Table 2

FPCU Degree Summary

\begin{tabular}{|l|l|}
\hline Number of Degrees & FPCU Degrees By Major \\
\hline 11 & Business or business related field (accounting, human resources) \\
\hline 2 & Public Administration \\
\hline 2 & Health Management \\
\hline 3 & Other (Interior Design, Education, Psychology) \\
\hline
\end{tabular}

Note: There is one degree each for Other (Degrees by Major). 
Appendix F: Data Analysis Coding Process

Table 3

Data Analysis Coding Process

\begin{tabular}{|c|c|c|c|}
\hline Code & Category & Research Question & Theme \\
\hline Motivating factors/choice & \multirow{8}{*}{$\begin{array}{l}\text { Motivations } \\
\quad \text { (Pre- } \\
\text { enrollment) }\end{array}$} & \multirow{8}{*}{$\begin{array}{l}\text { Why did FPCU } \\
\text { graduates choose to } \\
\text { attend a for-profit } \\
\text { college? }\end{array}$} & \multirow{8}{*}{$\begin{array}{l}\text { Access \& } \\
\text { Choice }\end{array}$} \\
\hline $\begin{array}{l}\text { Degree Purpose \& } \\
\text { Expectations }\end{array}$ & & & \\
\hline Benefits of online courses & & & \\
\hline Enrollment timeframe & & & \\
\hline Career goals & & & \\
\hline $\begin{array}{l}\text { School referral and } \\
\text { selection }\end{array}$ & & & \\
\hline Expectations & & & \\
\hline Costs \& Financial Aid & & & \\
\hline Class Size & \multirow{6}{*}{$\begin{array}{l}\text { Experience } \\
\text { (Enrolled } \\
\text { FPCU } \\
\text { Student) }\end{array}$} & \multirow{6}{*}{$\begin{array}{l}\text { What were the } \\
\text { experiences of FPCU } \\
\text { graduates in college? }\end{array}$} & \multirow{6}{*}{ Student Support } \\
\hline Technology & & & \\
\hline Majors/Area of Study & & & \\
\hline Support services & & & \\
\hline Professor availability & & & \\
\hline Program/Course Structure & & & \\
\hline Degree completion & \multirow{4}{*}{$\begin{array}{l}\text { Outcomes } \\
\quad \text { (Post- } \\
\text { Graduation } \\
\text { Experience) }\end{array}$} & \multirow{4}{*}{$\begin{array}{l}\text { What were the FPCU } \\
\text { graduates' experiences } \\
\text { upon completing their } \\
\text { degrees? }\end{array}$} & \multirow{3}{*}{$\begin{array}{l}\text { Degrees of } \\
\text { Impact \& } \\
\text { Satisfaction }\end{array}$} \\
\hline School recommendation & & & \\
\hline $\begin{array}{l}\text { Post-Graduation } \\
\text { employment status }\end{array}$ & & & \\
\hline Student-loan debt & & & $\begin{array}{l}\text { Return on } \\
\text { Investment }\end{array}$ \\
\hline
\end{tabular}


Appendix G: Thematic Descriptions

Table 4

Thematic Descriptions

\begin{tabular}{ll}
\hline Theme & Descriptions \\
\hline Access \& Choice & $\begin{array}{l}\text { 1. Access refers to the specified motivating factors for pursuing a post- } \\
\text { secondary credential. Participants sought access to additional career } \\
\text { opportunities and reported that obtaining a degree would provide the } \\
\text { access to those career goals. Choice refers to how participants selected } \\
\text { the FPCU from which they eventually graduated. A majority of the } \\
\text { participants were referred by a friend, family member or trusted } \\
\text { associate and selected the FPCU primarily based on that referral. } \\
\text { Additionally, participants specified the need for "flexibility" and } \\
\text { "convenience" as decision factors. }\end{array}$ \\
Student Support & $\begin{array}{l}\text { 2. Student Support refers to the support participants received during } \\
\text { their tenure enrolled at an FPCU. Participants reported that they } \\
\text { received professor assistance and were either "supported" or } \\
\text { "encouraged" by their academic advisor. }\end{array}$ \\
Degrees of Impact \& & $\begin{array}{l}\text { 3. Participants described the outcome of earning a degree from an } \\
\text { FPCU from a career viewpoint. The study participants indicated if and } \\
\text { how their FPCU degree affected their career advancement. The } \\
\text { satisfaction component refers to the extent to which the participants } \\
\text { were satisfied with their academic credential. Additionally, the } \\
\text { participants specify their culminating experience. }\end{array}$ \\
Returns on & $\begin{array}{l}\text { 4. The study participants indicated the perceived degree value or worth } \\
\text { in terms of overall satisfaction and the incurred financial expenses } \\
\text { associated with obtaining the degree. Further, each participant } \\
\text { addresses the cost and student loan factor. }\end{array}$ \\
&
\end{tabular}


VITA

TANIA FREDERIC ABOUZEIDE

Born, Brooklyn, New York

2005

Bachelor of Business Administration

Florida International University

Miami, Florida

$2006-2011$

Program Coordinator

Florida International University

Miami, Florida

2010

School Counseling Intern

Richmond Heights Middle School

Miami, Florida

2010

Master of Science in Counselor Education

Florida International University

Miami, Florida

$2011-2012$

Instructor First-Year Experience (SLS 1501)

Florida International University

Miami, Florida

$2011-2014$

Senior Academic Advisor

Florida International University

Miami, Florida

$2014-2018$

Assistant Director, Graduate Business Programs

University of Miami

Coral Gables, Florida

2015 - Present

Adjunct Instructor - Online Success Strategies (SNU 107)

Southern New Hampshire University

Manchester, New Hampshire

$2016-2017$

Advisor, Yellow Rose Society

University of Miami

Coral Gables, Florida 
2018 - Present

$2018-2019$

2019 - Present

2019 - Present

2020
Member, University of Miami Women's Commission University of Miami

Coral Gables, Florida

Associate Director, Graduate Business Programs University of Miami

Coral Gables, Florida

Advisor, Black Business Student Association

University of Miami

Coral Gables, Florida

Director, Graduate Advising \& Student Services

University of Miami

Coral Gables, Florida

Doctoral Candidate

Florida International University

Miami, Florida

\section{PRESENTATIONS \& PANELS}

Abouzeide, T. (2012, March). Who do I report to? How to succeed in a multimanagement environment. Presenter. National Academic Advising Association Region 4 International Conference. Miami, Florida.

Abouzeide, T. (2019, April). Navigating your professional journey. Moderator, Women's Commission Professional Development Series, Coral Gables, Florida.

Abouzeide, T (2019, March). Advancing your career to the next level. Panelist at Spring Advisors' Conference, Florida International University, Miami, Florida. 